UNIVERSIDADE DE BRASÍLIA - UnB

INSTITUTO DE GEOCIÊNCIAS - IG

PROGRAMA DE PÓS-GRADUAÇÃO - GEOCIÊNCIAS APLICADAS

DISSERTAÇÃO DE MESTRADO

\title{
ESTUDO DA CAPACIDADE DE INFILTRAÇÃO EM SISTEMAS DE RECARGA ARTIFICIAL DE AQUÍFEROS CONTAMINADOS NO DISTRITO FEDERAL
}

Maria Dulcinea Xavier Nunes Orientador: Prof. José Elói Guimarães Campos 
UNIVERSIDADE DE BRASÍLIA - UnB

INSTITUTO DE GEOCIÊNCIAS - IG

PROGRAMA DE PÓS-GRADUAÇÃO - GEOCIÊNCIAS APLICADAS

DISSERTAÇÃO DE MESTRADO

\title{
ESTUDO DA CAPACIDADE DE INFILTRAÇÃO EM SISTEMAS DE RECARGA ARTIFICIAL DE AQUÍFEROS CONTAMINADOS NO DISTRITO FEDERAL
}

\author{
Maria Dulcinea Xavier Nunes
}

\section{Banca Examinadora:}

Prof. Dr. José Eloi Guimarães Campos (Universidade de Brasília)

Prof. Dr. Luciano Soares da Cunha (Universidade de Brasília)

Dr. Fernando Roberto de Oliveira (Agência Nacional de Águas) 


\section{AGRADECIMENTOS}

A Deus, que em 2011, me concedeu, novamente, a vida de presente!

Ao meu orientador, Prof. José Eloi Guimarães Campos, pela paciência, pela motivação em aprender mais, pelo conhecimento repassado e incentivo à realização deste trabalho.

Ao Instituto de Geociências da Universidade de Brasília pelo apoio logístico para realização deste trabalho.

Ao meu marido, cuja ajuda em todos os sentidos, foi fundamental para que este trabalho fosse realizado.

Ao meu filho, Júlio César, pelo companheirismo e auxilio nas amostragens e medições.

À minha mãe e meus irmãos pela força e carinho.

Ao DER- Departamento de Estradas de Rodagens do Distrito Federal, na pessoa do Diretor Geral Eng. ${ }^{\circ}$ Henrique Luduvice pela prontidão em disponibilizar os caminhões pipas para o estudo e aos colegas Eng. ${ }^{\circ}$ Geraldo, Eng. ${ }^{o}$ Bruno, Eng. ${ }^{o}$ Paulo Robert, Eng. ${ }^{\circ}$ Leda, Eng., ${ }^{\circ}$ Cirino e Encarregado Aparecido.

Aos motoristas do DER/DF Gilberto e ajudante Osvaldo do $2^{\circ} \mathrm{DR}$, do $4^{\circ} \mathrm{DR}$ e em especial ao motorista Ilton Praxedes pela valorosa contribuição.

À Dani Castanheira pelo companheirismo e incentivo e à Michelle, Geóloga da CAESB, pela disponibilização dos dados do poço.

Aos colegas da Diretoria de Meio Ambiente/DER-DF, em especial, minha chefe Eng. ${ }^{a}$ Patrícia, pela compreensão e incentivo.

Ao Condomínio San Diego, na pessoa do Sr. Jorge e seus auxiliares, Edmar, Sr. Sebastião e outros pela gentileza em permitir a construção do Projeto Piloto, bem como utilização das instalações do condomínio.

Ao Sr. Demar, uma pessoa muito especial que permitiu o acesso à sua propriedade para coleta de água nas nascentes do Ribeirão Taboca. Uma ajuda valorosa na indicação dos melhores locais de amostragens.

À Gabriella e ao Neiva, pelas valorosas contribuições. 


\section{DEDICATÓRIA}

In Memorian

A meu saudoso e querido pai, Izaltino, que lá, bem no inicio de tudo acreditou em mim, sonhou comigo os meus sonhos e passou noites em claro para que eu pudesse estar aqui. 


\section{Sumário}

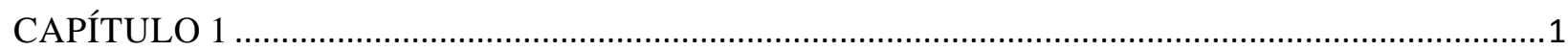

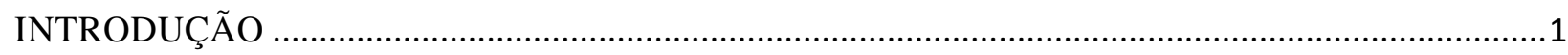

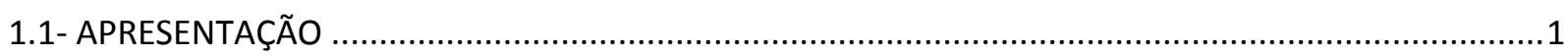

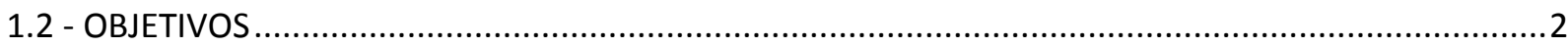

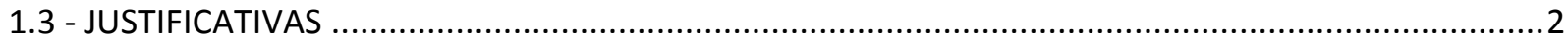

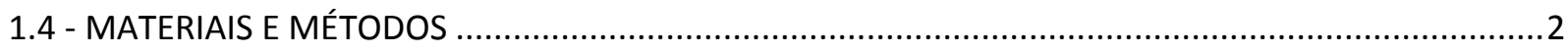

1.4.1 - Implantação do Sistema de Recarga Artificial..............................................................................

1.5 - LOCALIZAÇÃO

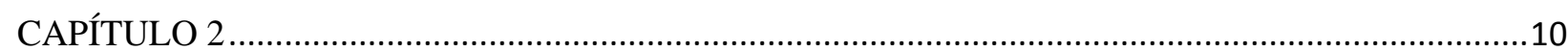

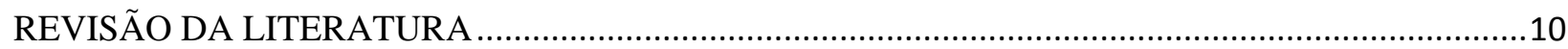

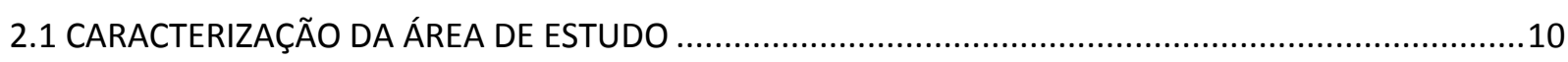

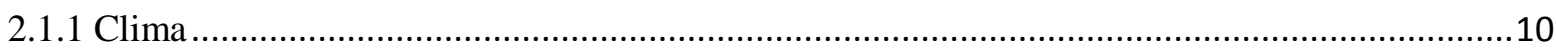

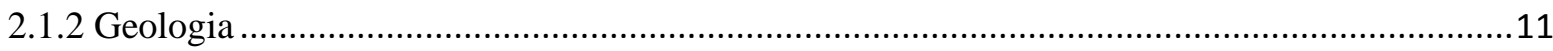

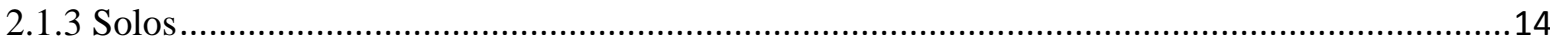

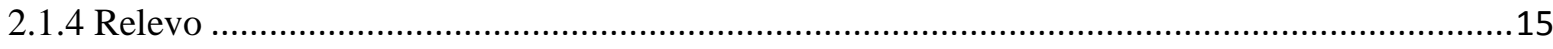

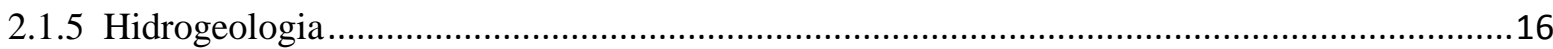

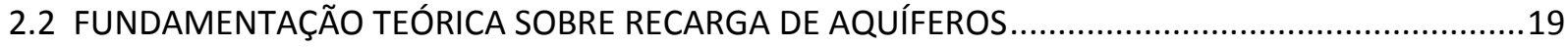

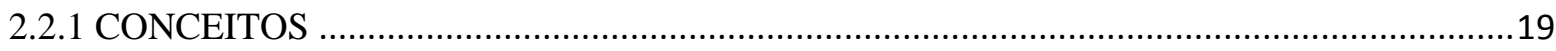

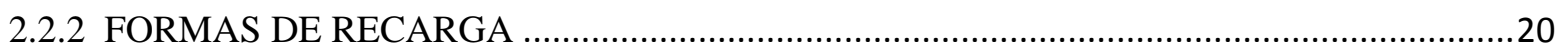

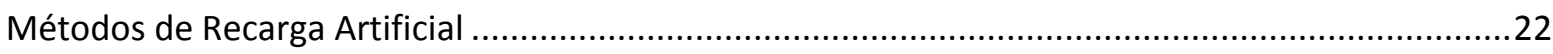

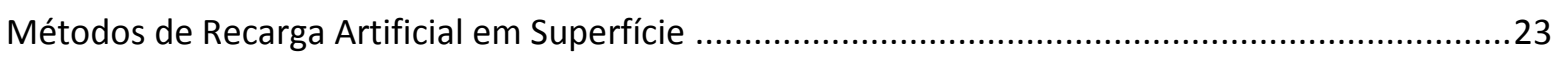

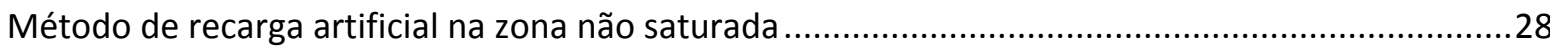

Métodos de Recarga Artificial em Profundidade ..............................................................................

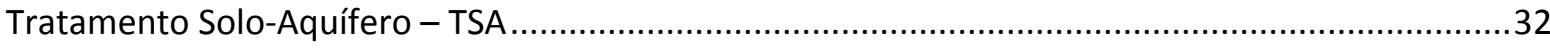

2.2.3 APLICAÇÕES DA TÉCNICA DE RECARGA ARTIFICIAL DE AQUÍFEROS NO MUNDO

.34

2.2.4 APLICAÇÕES DA TÉCNICA DE RECARGA ARTIFICIAL DE AQUÍFEROS NO BRASIL

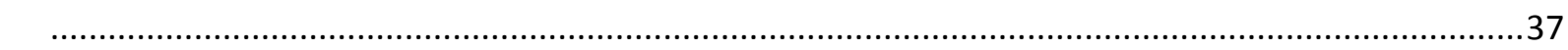

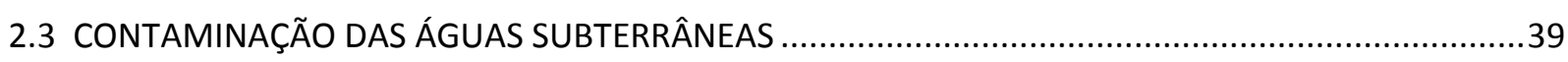

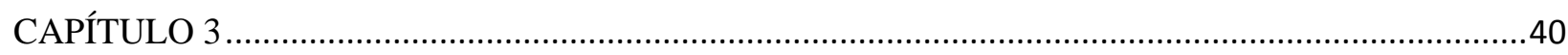

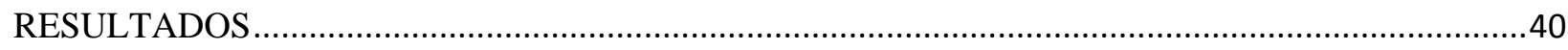

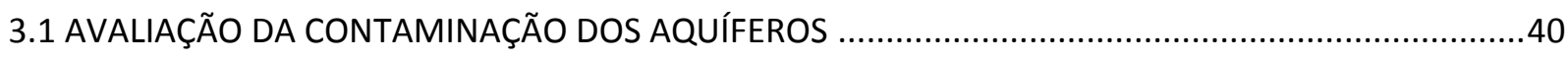

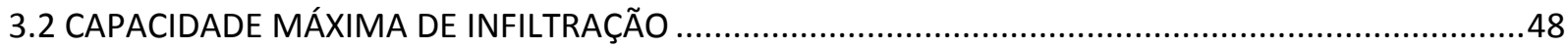

3.2.1 PROJETO PILOTO I- CONDOMÍNIO SAN DIEGO ..........................................................48 
3.2.2 PROJETO PILOTO II- CONDOMÍNIO PRIVE

3.3 TEMPO DE CHEGADA DAS ÁGUAS DE INFILTRAÇÃO.

3.3.1 PROJETO DE RECARGA PILOTO I- CONDOMÍNIO SAN DIEGO .49

3.3.2 PROJETO DE RECARGA PILOTO II - CONDOMÍNIO PRIVÊ .51 3.4 ESTIMATIVAS DOS VOLUMES PASSÍVEIS DE RECARGA NO CONDOMÍNIO SAN DIEGO E PRIVÊ. . .52

3.4.1 CÁLCULO DOS VOLUMES ESTIMADOS DE RECARGA ARTIFICIAL POTENCIAL NO CONDOMÍNIO SAN DIEGO.

3.4.2 CÁLCULO DOS VOLUMES ESTIMADOS DE RECARGA POTENCIAL NO CONDOMÍNIO PRIVÊ. .54

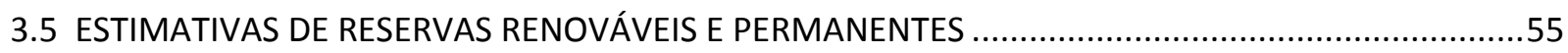

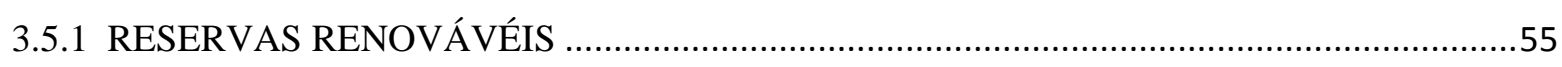

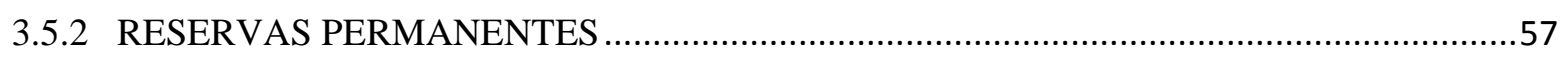

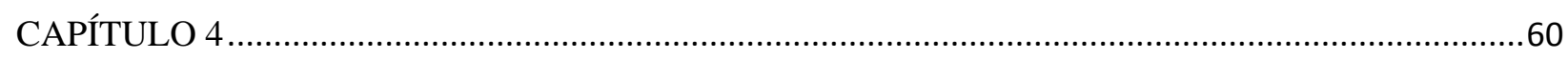

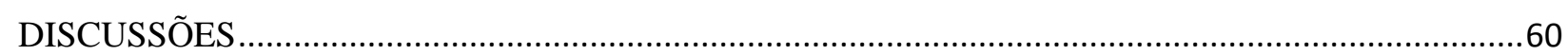

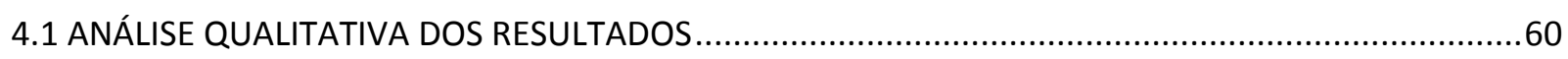

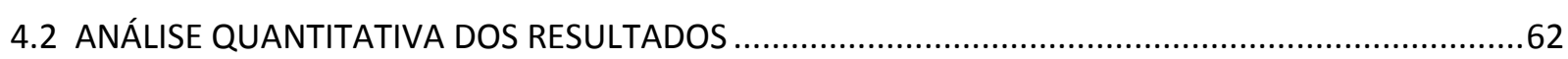

4.3 ANÁLISE DA CAPACIDADE DE RECARGA E CENÁRIOS FUTUROS ...................................................63

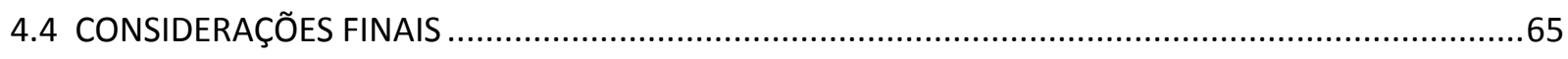

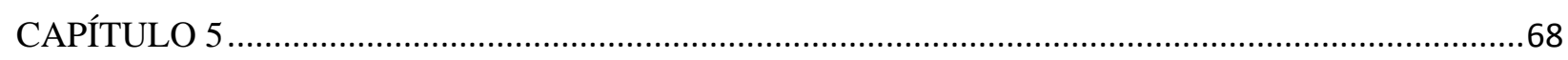

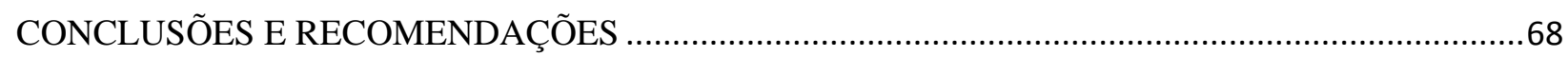

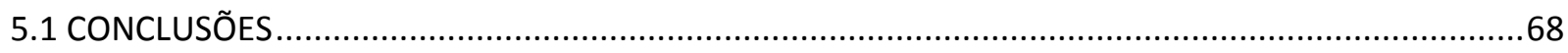

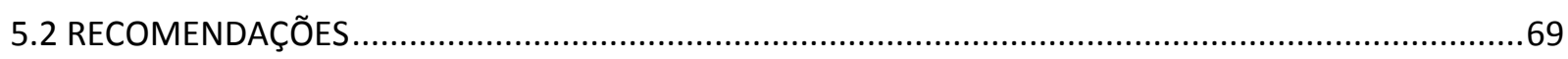

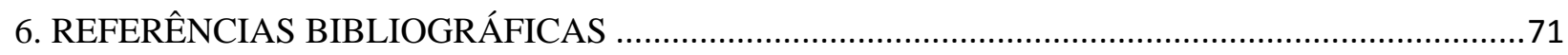




\section{INDICE DE FIGURAS}

Figura 1.1 - Caixa de infiltração sem revestimento/preenchimento e depois de concluída. Condomínio San Diego.

Figura 1.2 - Caminhão pipa utilizado e início da injeção de água na caixa de infiltração ............................5

Figura 1.3 - Caixa de infiltração e poço escavado, situados no Condomínio Privê Lago Norte....................6

Figura 1.4 -Sistema de recarga artificial proposto para locais em que ocorrem latossolos ou aterros espessos e permeáveis (Campos 2012).

Figura 1.5 - Situação das áreas em estudo (em amarelo Condomínio San Diego e em vermelho

Condomínio Privê) no território do Distrito Federal.

Figura 1.6 - Localização do Condomínio Privê do Lago Norte, Região Administrativa XVIII com destaque em vermelho para o ponto do sítio do ensaio, Fonte: Google Earth, 2016......

Figura 1.7 - Localização do Condomínio San Diego com destaque em vermelho para o ponto do sítio do ensaio, no Setor Habitacional Jardim Botânico - Região Administrativa XXVII Fonte: Google Earth, 2016. 9

Figura 2.1 - Distribuição anual dos totais mensais de precipitação e temperatura da Estação Brasília nos períodos de 1963 a 1990 (Fonte: Baptista, 1998).

Figura 2.2 - Mapa de Isoietas do Distrito Federal (Fonte: Gonçalves, 2007. Disponível em:

http://www.zee-df.com.br).

Figura 2.3 - Mapa geológico do Distrito Federal com destaque para a área em que foi instalado o sistema piloto de recarga artificial. Fonte: Atualizado de Freitas-Silva \& Campos, 1998.

Figura 2.4 - Bloco de quartzito branco com manchas de oxidação, exposto a partir das obras de implantação de infraestrutura do Residencial Jardins do Lago, Quadra 1

Figura 2.5 - Exposição de fácies pelítica de metarritmito arenoso, exposto próximo à área de instalação do sistema piloto de recarga artificial.

Figura 2.6 - Exposição de ardósia roxa da Formação Ribeirão do Torto do Grupo Paranoá que ocorre no Condomínio Privê Lago Norte.

Figura 2.7 - Mapa de solos do Distrito Federal com destaque (círculos azuis) para a área em que foram instalados os sistemas pilotos de recarga artificial (Gonçalves 2006).

Figura 2.8 - Mapa geomorfológio do Distritro Federal. Em amarelo as áreas de Planos Elevados; em azul os Planos Intermediários; em verde o compartimento dos Vales Dissecados; em rosa Rebordos e em vermelho as Rampas Íngremes. Proposta de compartimentação geomorfológica do Distrito Federal.Fonte: Adaptado de Novaes Pinto, 1994 e Martins \& Baptista, 1998.

Figura 2.9 - Ilustração do Modelo de Única Superfície Potenciométrica sem confinamento. Nesse caso, o nível freático apresenta ampla oscilação anual e pode ser observado em solo ou rocha fresca. Condição comum quando ocorrem quartzitos em bordas de chapadas (Lousada \& Campos 2005).

Figura 2.10 - Modelo de Única Superfície Potenciométrica com confinamento, onde a superfície de saturação permanece no meio aquífero intergranular superior. SPMP - superfície potenciométrica do meio poroso permanece coincidente com a superfície potenciométrica do meio fraturado (Lousada \& Campos 2005).

Figura 2.11 - O ciclo hidrológico com destaque para os principais processos responsáveis pela circulação da água da atmosfera para a superfície e subsuperfície e novamente para a atmosfera (Fonte:

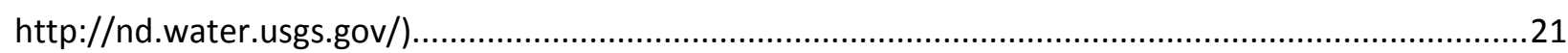

Figura 2.12 - Esquema simplificado de uma bacia de infiltração (extraído de Gale \& Dillon, 2005)..........24

Figura 2.13 - Exemplos de métodos de recarga à superfície (Topper et al., 2004 in SEWRPC, 2006)........25

Figura 2.14 - Recarga em planície de inundação com valas e canais de desvio (extraído de ALMEIDA, 2011). 
Figura 2.15-Esquema Simplificado de uma represa de armazenamento de areia implantada no leito de rios (extraído de Gale \& Dillon, 2005).

Figura 2.16 - Esquema simplificado de uma represa no leito do rio e pequena bacia de percolação a montante (extraído de Gale \& Dillon, 2005).

Figura 2.17 - Esquema simplificado de uma represa no leito do rio com zona de descarga (extraído de Gale \& Dillon, 2005).

Figura 2.18 - Esquema simplificado de uma Barreira subterrânea no leito de um rio (extraído de Gale \& Dillon, 2005).

Figura 2.19 - Valas de infiltração, com uso de água de chuva captada em telhados.

Figura 2.20 - Exemplos de métodos de recarga artificial em profundidade, na zona não saturada (Topper et al., 2004 in SEWRPC, 2006).

Figura 2.21 - Esquema de métodos de injeção direta (Topper et al., 2004 in SEWRPC, 2006).................31 Figura 2.22 - a) Ilustração esquemática de recarga no sistemas Aquifer Storage and Recovery (ASR) e b) Aquifer Storage Transfer and Recovery (ASTR)

Figura 2.23 - Injeção em dolinas como exemplo de recarga em profundidade. Fonte: www.panoramio.com/photo/68707856 (in Monteiro, 2013).

Figura 3.1 - Mapa do Enquadramento dos Corpos Hídricos Subterrâneos do Distrito Federal - Diagnóstico (Castanheira, 2016).

Figura 3. 2 Gráficos de tendência de elevação dos teores de $\mathrm{NO}_{3}, \mathrm{Cl}^{-}$e $\mathrm{Na}^{+}$. Amostras coletadas na saída do poço e análises realizadas pelo LAMIN - Laboratório de Análises Minerais do Serviço Geológico do Brasil.

Figura 33 -Localização dos poços amostrados no Condomínio San Diego e da Hydrate Água Mineral Natural (em amarelo) e das nascentes amostradas que fluem para o Ribeirão Taboca (em azul).

Figura 3.5 a) Vista geral do local de coleta- pontos 1 e 4 e b) Local da coleta. A água desta nascente é captada por bomba e utilizada para consumo pelos moradores da Chácara. Apresentou os menores valores do parâmetro Nitrato. O local apresenta ambiente mais preservado.

Figura 3.4 a) Confluência das nascentes do Ribeirão Taboca, pontos de coleta 5 e 6 e b) detalhe do ponto 6 mostrando exposição do metarritmito da Formação Córrego do Sansão. ...........................................46 Figura 3.6 -Variação do NA do poço do Condomínio San Diego de Jan a Out/2016................................51 Figura 3.7-Série histórica da CAESB. Dados do poço SD 01situado próximo ao Sistema Piloto de Recarga I.

Figura 38 - Imagem da poligonal do Condomínio San Diego mostrando as coberturas das residências com sombreamento em amarelo.

Figura 39 - Imagem da poligonal do Condomínio Privê Lago Norte mostrando as coberturas das casas em amarelo.

Figura 3.10 - Série histórica da CAESB. Dados dos níveis de água do poço SD 01, próximo ao Sistema Piloto de Recarga I.

Figura 4. 1 - Representação esquemática das condições de circulação das águas subterrâneas a partir de caixa de recarga artificial (Projeto de Recarga Piloto I).

Figura 4.2 - Representação esquemática de modelo de circulação das águas subterrâneas proposto para o Projeto de Recarga Piloto II. 


\section{RESUMO}

O presente projeto de pesquisa aplicada tem os seguintes objetivos 1) avaliar a capacidade máxima de infiltração em sistemas de recarga artificial de aquíferos em áreas urbanas, 2) quantificar os volumes médios passíveis de recarga em áreas de condomínios horizontais do Distrito Federal, 3) estimar o tempo necessário para diluição de cargas contaminantes e 4) verificar a extensão das plumas de contaminação na região do Setor Habitacional Jardim Botânico.

A metodologia consistiu no diagnóstico da área e seu entorno imediato, ensaios hidráulicos com injeção de água em caixas de infiltração, análise in situ da qualidade das águas coletadas em poços e nascentes. Dois sistemas de recarga artificial foram construídos: sistema de Recarga Piloto I (no Condomínio San Diego) e Sistema de Recarga Piloto II (Condomínio Privê Lago Norte), ambos visando à recarga de aquíferos fraturados, respectivamente, Subsistema $\mathbf{R}_{\mathbf{3}} / \mathbf{Q}_{\mathbf{3}}$ e Subsistema A.

Os resultados obtidos mostram que: 1) Os sistemas de recarga artificial propostos apresentam alta efetividade para induzir a infiltração de águas de chuvas coletadas nas coberturas de edificações em condomínios horizontais; 2) Os volumes potenciais de infiltração, considerando diferentes cenários, são relevantes e podem auxiliar na remediação in situ de aquíferos contaminados em prazos variáveis entre 5 e 15 anos dependendo do grau de adesão da população e do meio físico local; 3) A eficiência da recarga artificial pode ser definida pela capacidade máxima de infiltração nos diferentes sistemas de recarga e varia conforme os diferentes controles do meio físico local, 4) A região do Condomínio San Diego já tem aquíferos contaminados pela infiltração dos efluentes, constatação feita pelo monitoramento da qualidade das águas dos poços de abastecimento e pela presença de nitrato e amônia nas águas das nascentes que são exutórios destes aquíferos.

As recomendações para continuidade da pesquisa incluem: 1) instalação de um número maior de sistemas de recarga piloto, nas proximidades de outros poços tubulares com contaminação comprovada, para se ter maior controle da dispersão e migração das águas infiltradas; 2) desenvolvimento de estudo geofísico previamente à instalação das caixas de recarga, de forma a se ter maior controle da escolha dos pontos para injeção de água de precipitação; 3) realização de estudos de isótopos estáveis para melhor controle dos tempos de chegada das águas de recarga artificial; 4) operação de sistemas de recarga artificial alimentado por águas de precipitação e realização do monitoramento por pelo menos dois anos hidrológicos consecutivos; 5) após o início de implantação da recarga artificial de forma mais ampla as nascentes da borda da chapada deverão ser o principal alvo de monitoramento para verificação da efetividade da ação.

Palavras-chave: recarga artificial, capacidade de infiltração, aquífero contaminado. 


\section{ABSTRACT}

This applied research project aims to 1) evaluate the maximum capacity of infiltration in artificial recharge of aquifers systems in urban areas, 2) quantify the average volumes likely to recharge in areas of condominiums of Federal District, Brazil, 3) estimate the time needed to dilution of nitrate contaminant plumes and 4) check the extent of the contamination plumes in the housing areas.

The methodology consisted in the investigation of the area and its immediate surroundings, hydraulic test with water injection in infiltration digs and in situ analysis of water quality collected in wells and springs. Two artificial recharge systems were installed: Pilot Recharge System I (San Diego Condominium) and Pilot Recharge System II (Privê North Lake Condominium), both for fractured aquifers recharge, respectively, $\mathbf{R}_{\mathbf{3}} / \mathbf{Q}_{\mathbf{3}}$ Subsystem and A Subsystem (Paranoá Aquifer System).

The main results show that: 1) the proposed artificial recharge systems feature high effectiveness to induce infiltration of rainwater collected on roofs of buildings into the soil and deep aquifers; 2) potential infiltration volumes, considering different scenarios are relevant and can assist in-situ remediation of contaminated aquifers in periods between 5 and 15 years depending on the degree of population compliance and the local environment (soil, declivity and geology); 3) the efficiency of artificial recharge can be defined by the maximum capacity of infiltration in different recharge systems and varies according to the different local controls, 4) the aquifers of San Diego Condominium is already contaminated by leakage of wastewater, and it was established by monitoring water quality of supply wells and the presence of nitrate and ammonia in springs waters that are discharge of these aquifers.

Recommendations for ongoing research include: 1) installing of a larger number of pilot recharge systems in the vicinity of proven contaminated wells, to have greater control of dispersion and migration of the infiltrated water; 2) development of geophysical study prior to recharge digs construction, in order to have greater control of the points for injection of precipitation water; 3 ) studies of stable isotopes to better control the arrival times of the artificial recharge waters; 4) operation of artificial recharge systems powered by water from precipitation and realization of monitoring for at least two hydrological years; 5) after the start of the of artificial recharge more generally the springs from the plateau border should be the main target to verification of the effectiveness of the purposed artificial recharge systems.

Keywords: artificial recharge, infiltration capacity, contaminated aquifer. 


\section{CAPÍTULO 1 \\ INTRODUÇÃO}

\section{1- APRESENTAÇÃO}

A população do DF saltou de pouco mais de 64 mil habitantes no ano de sua inauguração para cerca de 2,5 milhões de habitantes em 2007, o que representa um aumento de aproximadamente $3.700 \%$, segundo o Instituto de Pesquisa Econômica Aplicada (IPEA), em seu relatório - "Brasília: Impactos Econômicos da Capital no Centro-Oeste e no País".

Ao longo de, pelo menos duas décadas, a ocupação de grande parte do Distrito Federal se deu a revelia das normas legais. O aumento do crescimento demográfico gerou uma demanda habitacional reprimida para a população com renda média a alta que aliada à ausência de políticas públicas impulsionaram a implantação de condomínios irregulares no Distrito Federal.

A implantação desses condomínios residenciais edificados fora do alcance das redes de coleta e tratamento da Caesb com ocupações de elevada densidade humana que desde os anos 1990 infiltram os efluentes na zona não saturada dos aquíferos levou à degradação dos mananciais superficiais e subterrâneos o que exige instrumentos de gestão que possam melhorar a disponibilidade e a qualidade dos recursos hídricos.

O fracionamento do terreno natural e a efetiva ocupação urbana geram uma série de cargas potenciais para contaminação das águas subterrâneas com destaque para: efluentes domésticos em sistema de saneamento in situ, chorume derivado da decomposição de resíduos sólidos, infiltração de hidrocarbonetos em postos de combustível e serviços, resíduos químicos em áreas industriais, dentre outros.

Historicamente a região sempre utilizou a alternativa de esgotamento sanitário in situ. Apenas nos últimos anos a Companhia de Saneamento Ambiental de Brasília CAESB iniciou a implantação de redes de coleta e emissários para interligação com a Estação de Tratamento de Esgotos - ETE de São Sebastião, localizada a oeste.

As águas subterrâneas, embora sejam menos vulneráveis do que as superficiais podem ser afetadas por contaminações oriundas de atividades antrópicas, agrícolas e industriais. Em áreas urbanas a carga poluidora de esgotos domésticos constitui-se em um importante fator de contaminação das águas subterrâneas (Vieira et al. 2013)

Dados de monitoramento de análises químicas realizados em poços tubulares operados pela CAESB mostram que a poligonal da Região Administrativa Jardim Botânico já apresenta problema de qualidade das águas subterrâneas devido ao sistema de saneamento in situ que foi implantado desde o início da ocupação.

Resultados de análises químicas de águas de poços tubulares profundos operados pela 
CAESB (amostragem em julho / agosto de 2007) apresentam valores de alerta para nitrato, cloro e Fe total em poços de condomínios da região do Setor Habitacional Jardim Botânico. Resultados de $\mathrm{pH}$ e coliformes totais apresentam valores acima do máximo permissível em alguns poços da região.

No Distrito Federal a contaminação das águas freáticas e subterrâneas profundas já foi constatada em diferentes trabalhos (ex. Zoby, 1999), sendo as fontes difusas na forma de fossas sépticas e negras, as mais comuns.

\section{2 - OBJETIVOS}

O presente projeto de pesquisa aplicada tem como objetivos:

a) avaliar a capacidade máxima de infiltração em sistemas de recarga artificial de aquíferos em áreas urbanas;

b) quantificar os volumes médios possíveis de recarga em áreas de condomínios horizontais do DF;

c) estimar o tempo necessário para diluição de cargas contaminantes e

d) verificar a extensão das plumas de contaminação (poço + nascente) na região do Setor Habitacional Jardim Botânico.

\section{3 - JUSTIFICATIVAS}

O desenvolvimento do presente projeto se justifica pelo fato de a aplicação de técnicas de recarga artificial de aquíferos ser uma das alternativas para assegurar a disponibilidade hídrica e garantir a qualidade das águas superficiais e subterrâneas no futuro.

A implantação de condomínios causa impermeabilização das áreas de recarga, dificulta a infiltração das águas da chuva, minimiza a recarga dos aquíferos causando sua contaminação.

Outro ponto considerado importante é o fato de nunca terem sido desenvolvidos trabalhos de recarga artificial no Distrito Federal com foco na qualidade das águas, mas apenas com propósitos de ampliação das disponibilidades dos aquíferos.

\section{4 - MATERIAIS E MÉTODOS}

A metodologia consistiu, inicialmente, no diagnóstico da área e seu entorno imediato, mediante a caracterização geológica, geomorfológica e pedológica, bem como, a caracterização do aquífero.

Para avaliar os dados de qualidade das águas subterrâneas foram considerados os valores de referência estabelecidos pela Resolução CONAMA n 396/08 (BRASIL, 2008) que dispõe sobre a classificação e diretrizes ambientais para o enquadramento das águas subterrâneas e da Portaria do Ministério da Saúde (MS) n 2914/11 (BRASIL, 2011) que dispõe sobre os 
procedimentos de controle e de vigilância da qualidade da água para consumo humano e seu padrão de potabilidade.

Serão observados os procedimentos gerais estabelecidos na Resolução CNRH nº 91/2008 para o enquadramento dos corpos d'água superficiais e subterrâneos, as diretrizes da Resolução CNRH n ${ }^{\circ}$ 15/2001 para a gestão de águas subterrâneas e a Resolução CNRH no 153 que estabelece critérios e diretrizes para implantação de recarga artificial de aquíferos no território brasileiro.

Serão considerados ainda os dados da série histórica das análises dos poços do Saneamento Urbano da Companhia de Saneamento Ambiental de Brasília - CAESB e os dados obtidos por meio de monitoramento in situ da qualidade das águas por meio de sonda multi parâmetros. Serão analisadas águas das nascentes da borda da chapada bem como as águas retiradas de poços tubulares profundos do Condomínio San Diego e do poço escavado do Condomínio Privê 1.

\subsection{1 - Implantação do Sistema de Recarga Artificial}

Os sistemas de recarga devem se localizar a uma distância máxima de 20 metros do poço produtor em que serão realizadas as coletas de amostras de água e devem ser implantados distantes de edificações, muros, residências. Inicialmente as caixas serão alimentadas por água potável obtida de caminhões pipa para se ter maior controle dos volumes de injeção e facilitar os cálculos e dimensionamento dos sistemas de recarga artificial propostos. Posteriormente as caixas deverão ser alimentadas por água de chuva captada em coberturas de residências nos meses de maior índice pluviométrico, no sentido de aproveitar o excedente hídrico das precipitações, principalmente entre os meses de novembro e março.

Os sistemas deverão ser construídos preferencialmente nas áreas verdes dos lotes (geralmente áreas com coberturas de grama) o mais afastado possível das edificações para evitar eventuais problemas geotécnicos, como recalques em fundações, saturação em solos colapsíveis, entre outros.

Para os dois Projetos Piloto foi aplicado o sistema indireto de recarga artificial por caixas de infiltração, tipo Cadamuro (2002) para locais de solos espessos.

\subsubsection{1 - Projeto Piloto I}

A escolha do poço tubular profundo do Condomínio San Diego para a implantação do Projeto Piloto I considerou alguns fatores tais como facilidade de acesso, condições do perfil de alteração do solo na região e a contaminação do aquífero confirmada por resultados de análises que mostram valores de nitrato acima dos valores de background para águas subterrâneas locais.

Foi escavada a uma distância de 1,50 m do poço tubular, uma caixa cilíndrica de diâmetro de 1,00 m por 1,80 m de profundidade, preenchida com seixos rolados de quartzitos e veios de quartzo. Neste sistema foram infiltradas as águas dos diversos ensaios hidráulicos realizados. 

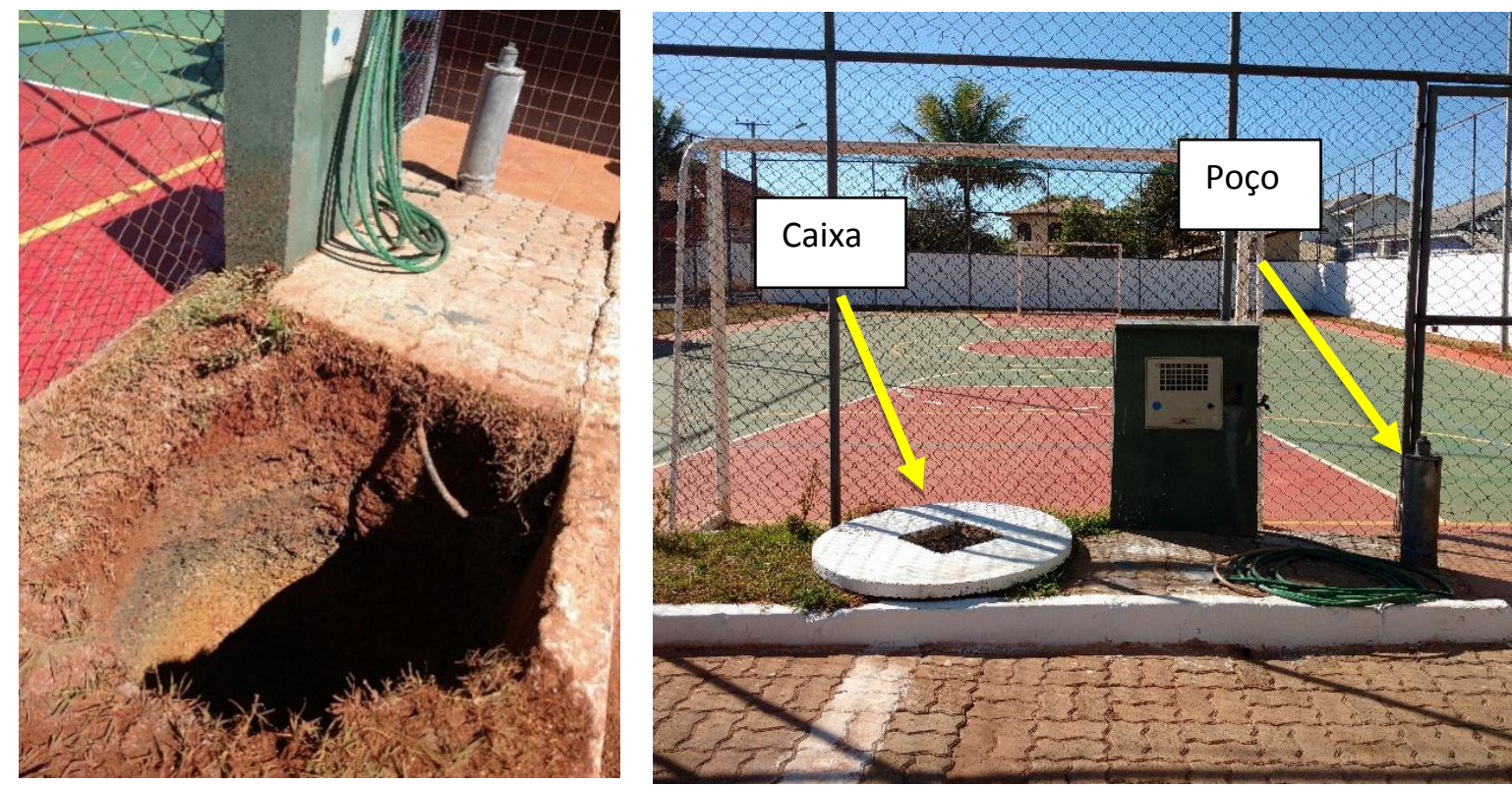

Figura 1.1 - Caixa de infiltração sem revestimento/preenchimento e depois de concluída. Condomínio San Diego.

A dificuldade de controlar o volume injetado a partir das calhas dos telhados, bem como necessidade de conciliar os períodos chuvosos com o período previsto para a conclusão da dissertação motivaram a utilização de caminhão pipa para injeção de água.

Foram realizados cinco ensaios hidráulicos e injetados 38.500 litros de água utilizando caminhão pipa com capacidade para 15.000 L (Figura 1.2). A água provinha de um poço profundo localizado no $3^{\circ}$ Distrito Rodoviário, em Samambaia e de uma nascente próxima ao $4^{\circ}$ Distrito no Paranoá. Foi feita captação também em um ponto de captação de água por caminhões pipa autorizado pela ADASA, Ponto $N^{\circ}$ 6, localizado na Vila Telebrasília, conforme Tabela 1.1.

\begin{tabular}{|c|c|c|}
\hline DATA & VOLUME & PONTO DE CAPTAÇÃO \\
\hline $12 / 05 / 2016$ & $4.500 \mathrm{~L}$ & Nascente Próxima ao $4^{\circ}$ DR- Paranoá \\
\hline $09 / 06 / 2016$ & $5.000 \mathrm{~L}$ & ${\text { Ponto }{ }^{\circ} 06 \text { - Vila Telebrasília- Brasília }}^{\text {Poço Profundo do } 3^{\circ} \text { DR - Samambaia }}$ \\
\hline $16 / 09 / 2016$ & $7.000 \mathrm{~L}$ & Poço Profundo do $3^{\circ}$ DR - Samambaia \\
\hline $26 / 09 / 2016$ & $7.000 \mathrm{~L}$ & Poço Profundo do $3^{\circ}$ DR - Samambaia \\
\hline 10/10/2016 & $15.000 \mathrm{~L}$ & \\
\hline TOTAL & $38.500 \mathrm{~L}$ & \\
\hline
\end{tabular}

Tabela 1.1 - Distribuição de volumes injetados em ensaios hidráulicos realizados no sistema piloto do Condomínio San Diego.

O processo de amostragem se deu por meio de diversas campanhas de coleta e análise da água retirada do poço por meio de amostrador tipo bailer. Inicialmente coletava-se água do caminhão pipa e do poço para análise utilizando instrumento de amostragem de multiparâmetros YSI ProDSS equipado com sistema de amostragem digital portátil para medição in situ de parâmetros, tais como: $\mathrm{T}\left({ }^{\circ} \mathrm{C}\right), \mathrm{P}(\mathrm{mm}$ de $\mathrm{Hg}), \mathrm{OD}(\%), \mathrm{OD}(\mathrm{mg} / \mathrm{l}), \mathrm{TDS}, \mathrm{C}(\mu \mathrm{S}), \mathrm{NH}+\mathrm{N}(\mathrm{mg} / \mathrm{l})$ e $\mathrm{NO}_{4+}{ }_{3} \mathrm{~N}$ 
$(\mathrm{mg} / \mathrm{l})$.

Foram feitas medições para determinação do nível de água do poço ao longo dos testes hidráulicos, além da medição da vazão de injeção.

Nos dois primeiros ensaios foi observado um intervalo de três dias para o início das coletas no poço e amostragem in situ.

No terceiro ensaio considerou-se um intervalo menor, de dois dias, para início das coletas e no quarto ensaio, amostrou-se a água no mesmo dia e ao longo de todo dia seguinte à injeção.

No quinto e último ensaio, coletou-se e amostrou-se no mesmo dia e nos nove dias seguintes. Antes do início do ensaio, foram diluídos $8 \mathrm{~kg}$ de cloreto de sódio $(\mathrm{NaCl})$ em 40 litros de água para funcionar como elemento traçador com o objetivo de se verificar a chegada das águas infiltradas no poço tubular profundo SD 01, próximo à caixa de infiltração.

Foram feitas coleta e análise in situ da água das nascentes do Ribeirão Taboca e determinados os mesmos parâmetros citados acima.
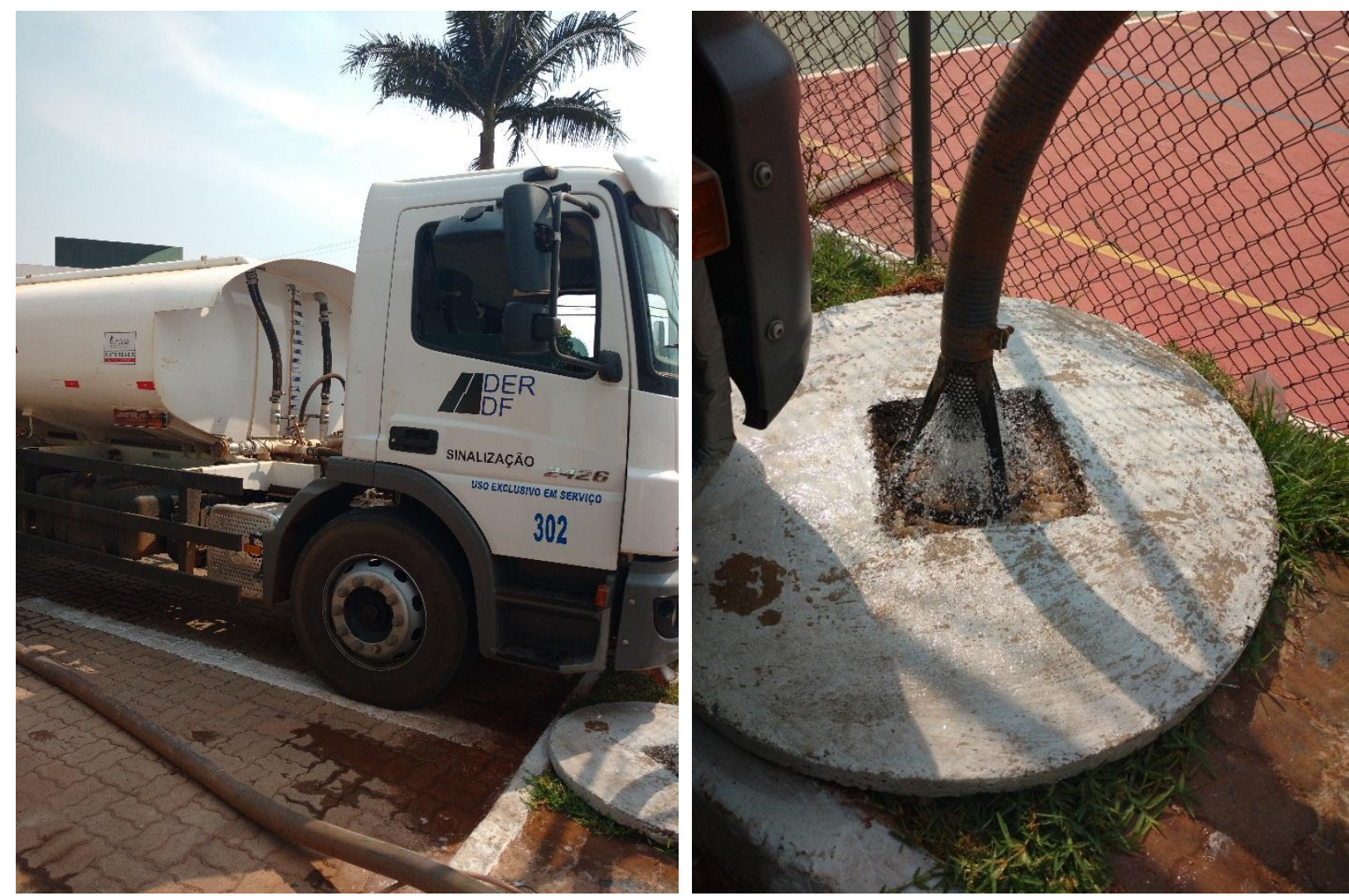

Figura 1.2 - Caminhão pipa utilizado e início da injeção de água na caixa de infiltração

\subsubsection{2 - Projeto Piloto II}

A escolha do local para a implantação do Projeto Piloto II considerou as condições construtivas usualmente encontradas em projetos residenciais, que consiste em corpo de aterro sobre solo natural para nivelamento do terreno. 
Neste caso foi construída uma caixa de recarga com 1,5 metros de profundidade, revestida de manilha, sobre aterro compactado a rolo em que foi utilizado Latossolo Vermelho argiloso, sobre um Cambissolo Háplico, a qual foi preenchida por blocos de quartzitos. Este piloto de recarga está situado a 2 metros de uma cisterna com nível d'água a 6,8 metros (Figura 1.3).
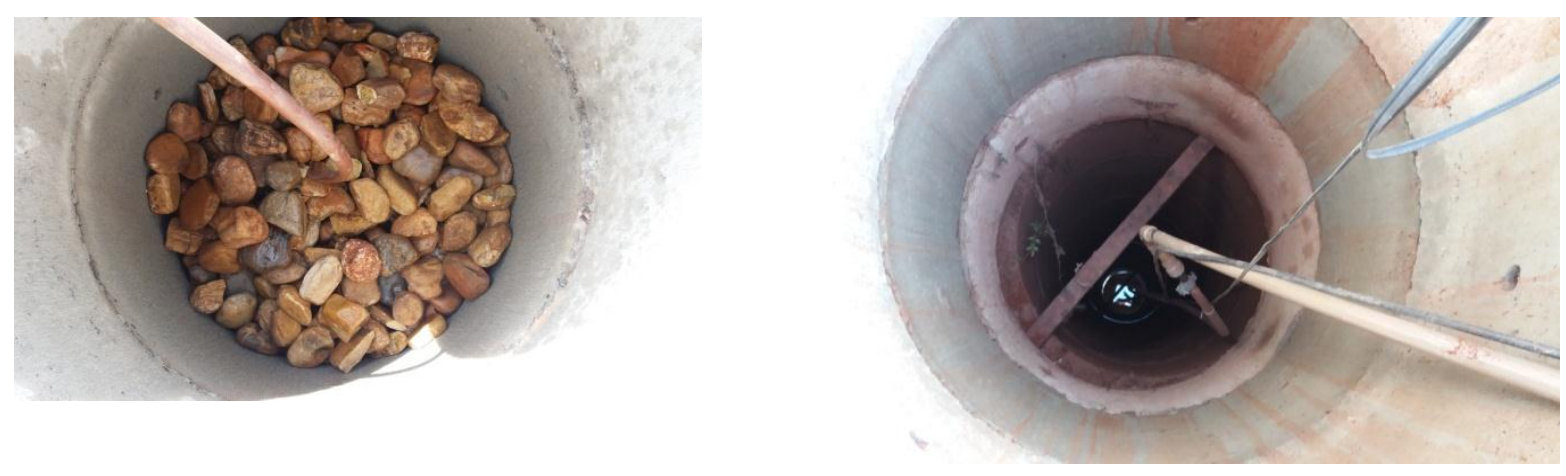

Figura 1.3 - Caixa de infiltração e poço escavado, situados no Condomínio Privê Lago Norte.

Neste caso foram realizados dois ensaios hidráulicos, o primeiro tendo como objetivo o entendimento do sistema de fluxo através do sistema aterro - solo natural e um segundo teste com o objetivo de se determinar a capacidade máxima de infiltração para subsidiar a capacidade de suporte do sistema piloto. No primeiro foram diluídos $4 \mathrm{~kg}$ de cloreto de sódio em $20 \mathrm{~L}$ de água e injetados na caixa de infiltração para funcionar como elemento traçador e possibilitar a verificação da chegada das águas infiltradas no poço escavado. A Tabela 1.2 traz os dados gerais dos testes hidráulicos.

\begin{tabular}{|c|c|c|}
\hline DATA & VOLUME(L) & PONTO DE CAPTAÇÃO \\
\hline 08/10/2016 & 3.100 & Água da CAESB \\
\hline 09/11/2016 & 5.000 & Caminhão Pipa \\
\hline TOTAL & $\mathbf{8 . 1 0 0}$ & \\
\hline
\end{tabular}

Tabela 1.2 - Distribuição de volumes injetados em ensaios hidráulicos realizados no sistema piloto do Condomínio Privê Lago Norte.

\subsubsection{3 - Sistema de Recarga por Caixas de Infiltração}

O sistema de recarga adotado utiliza caixas de infiltração, com as seguintes dimensões: formato cilíndrico, com 1,0 a 2,5 m de profundidade e 1 metro de diâmetro, preenchidas com material composto por cascalho lavado (tipo seixos - Figura 1.4). O sistema prevê a infiltração lateral em interfaces de horizontes de solos ou no contato saprolito rocha e infiltração vertical nas zonas de contato de fraturas abertas e as camadas de saprolitos e solos. Esta técnica de recarga será adotada nos locais de solos espessos e permeáveis ou aterros espessos com capacidade mínima de infiltração da ordem de $10^{-6} \mathrm{~m} / \mathrm{s}$. 


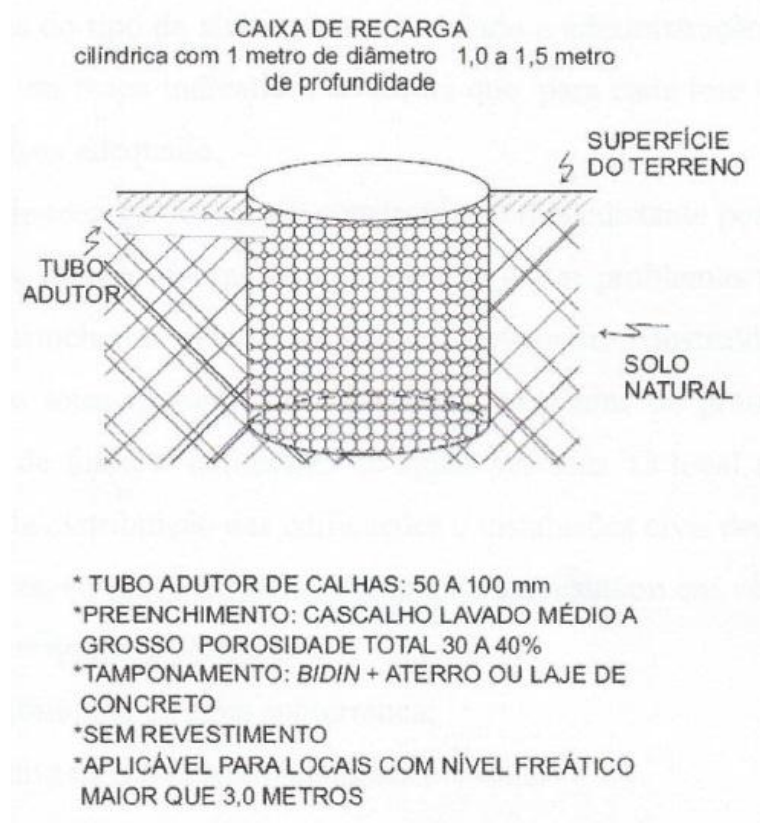

Figura 1.4 -Sistema de recarga artificial proposto para locais em que ocorrem latossolos ou aterros espessos e permeáveis (Campos 2012).

\subsubsection{4 - Resultados Esperados}

Os resultados esperados são:

- Diluir os contaminantes em um período de anos após o início de aplicação da prática de recarga artificial;

- Diminuir o escoamento superficial minimizando processos erosivos que se desenvolvem na jusante na bacia;

- Ampliar as reservas hídricas renováveis com qualidade compatível com água potável e

- Auxiliar na regulamentação das práticas de recarga artificial no Distrito Federal.

\section{5 - LOCALIZAÇÃO}

As áreas de estudo são localizadas na porção central do Distrito Federal na Região Administrativa XVIII Lago Norte e na Região Administrativa XVII Jardim Botânico (Figuras 1.5 a 1.7). Estas áreas atualmente são inseridas em zonas de dinamização urbana pelo Ordenamento Territorial do Distrito Federal - PDOT e constitui regiões de recarga natural das unidades hidrográficas Paranoá e Ribeirão Taboca.

Estas áreas serão denominadas ao longo desta Dissertação como Projeto Piloto I (Condomínio San Diego) e Projeto Piloto II (Condomínio Privê Lago Norte). 
Mapa de localização dos Condomínios Privé e San Diego

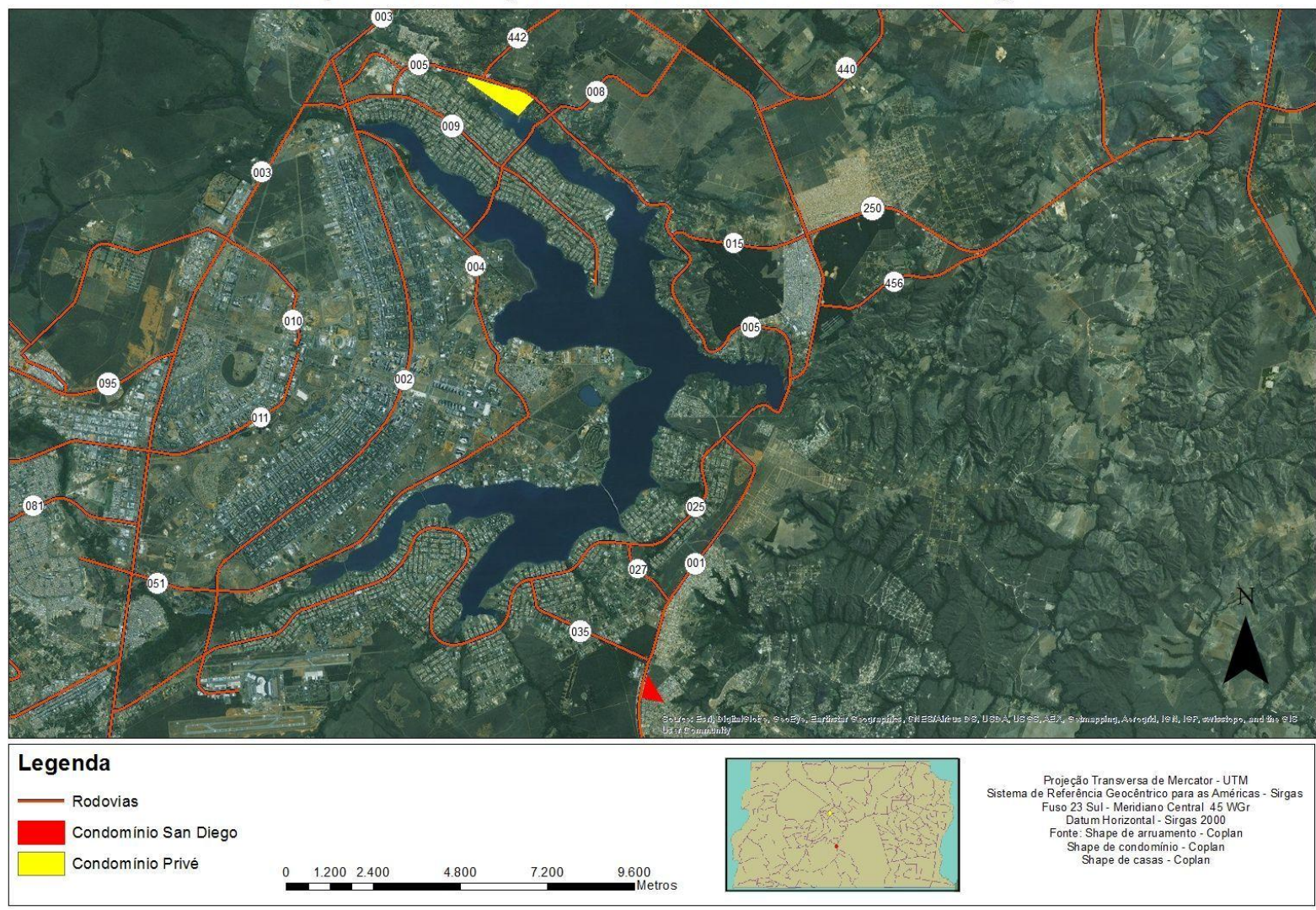

Figura 1.5 - Situação das áreas em estudo (em amarelo Condomínio San Diego e em vermelho Condomínio Privê) no território do Distrito Federal.

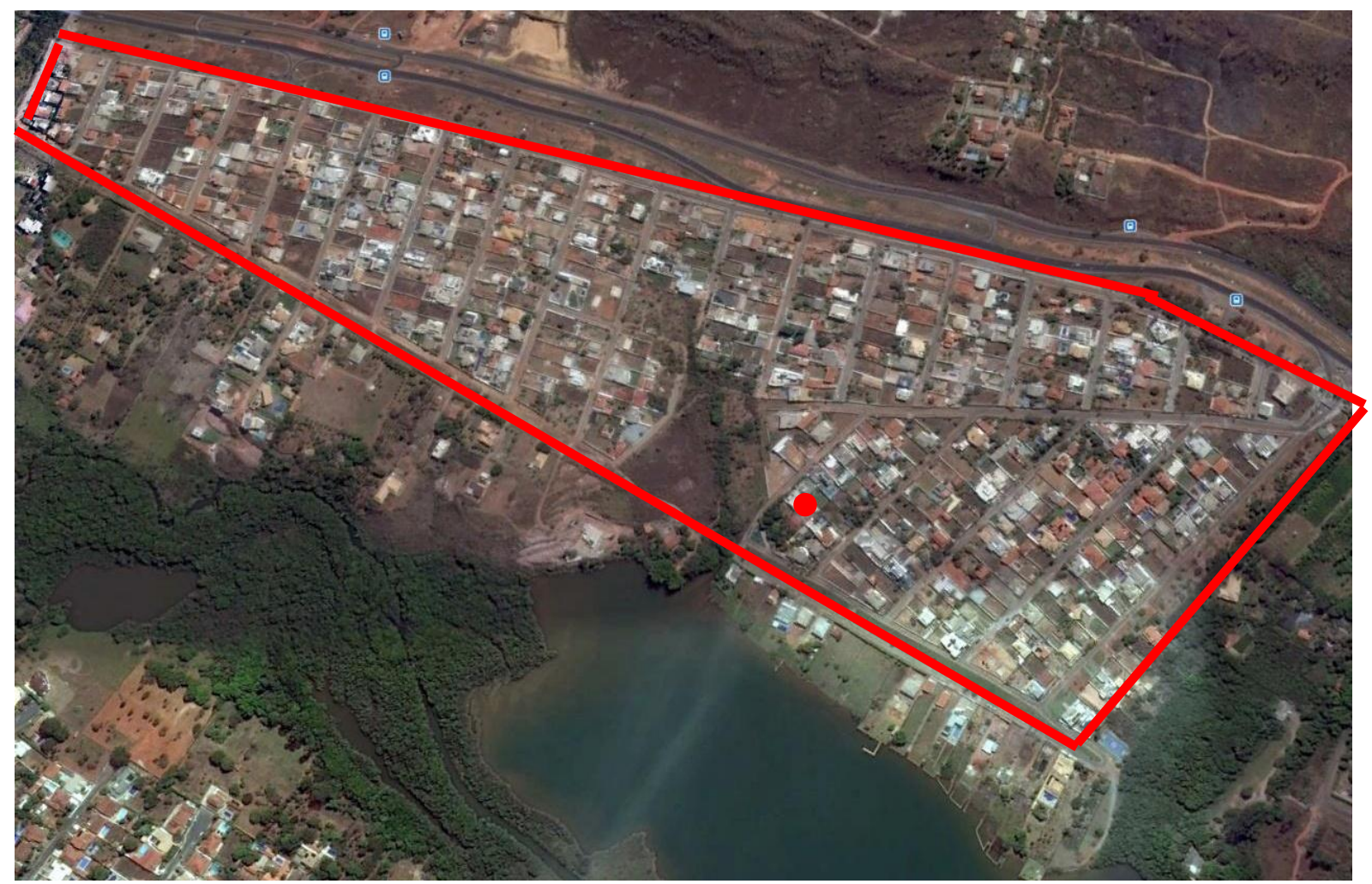

Figura 1.6 - Localização do Condomínio Privê do Lago Norte, Região Administrativa XVIII com destaque em vermelho para o ponto do sítio do ensaio, Fonte: Google Earth, 2016. 


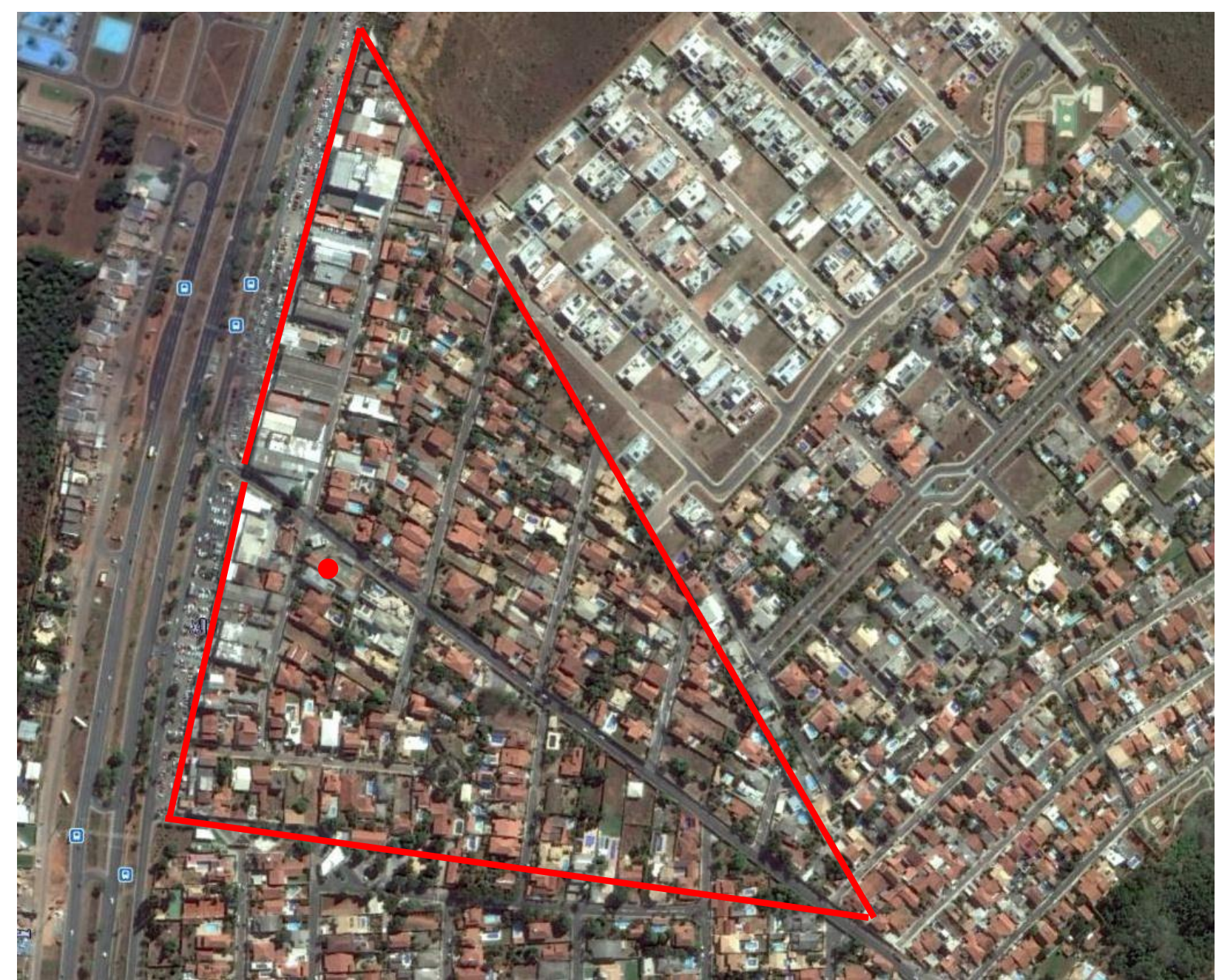

Figura 1.7 - Localização do Condomínio San Diego com destaque em vermelho para o ponto do sítio do ensaio, no Setor Habitacional Jardim Botânico - Região Administrativa XXVII Fonte: Google Earth, 2016. 


\section{CAPÍTULO 2}

\section{REVISÃO DA LITERATURA}

Os recursos hídricos subterrâneos constituem uma importante fonte de abastecimento de água potável em núcleos rurais e urbanos, mas a ocupação desordenada das áreas de recarga natural e sua consequente impermeabilização, além de causarem alterações no ciclo hidrológico, podem causar contaminação das águas subterrâneas.

Neste capítulo de revisão bibliográfica serão focalizados dois temas centrais necessários para o melhor entendimento da proposta desta Dissertação de Mestrado: a caracterização da área de estudo no âmbito do Distrito Federal e os conceitos e métodos para realização de recarga artificial de aquíferos.

\section{1 - CARACTERIZAÇÃO DA ÁREA DE ESTUDO}

\subsection{1 - Clima}

O clima na área pode ser caracterizado como a média das condições climáticas do Distrito Federal e é marcado pela forte sazonalidade, com duas estações contrastantes. O período entre maio e setembro é evidenciado pela baixa taxa de precipitação, baixa nebulosidade, alta taxa de evaporação, com baixas umidades relativas diárias. O período entre outubro e abril apresenta padrões distintos, sendo que os meses de dezembro a março concentram $47 \%$ da precipitação anual (Figura 2.1 e Tabela 2.1). A precipitação média anual é da ordem de $1500 \mathrm{~mm}$.

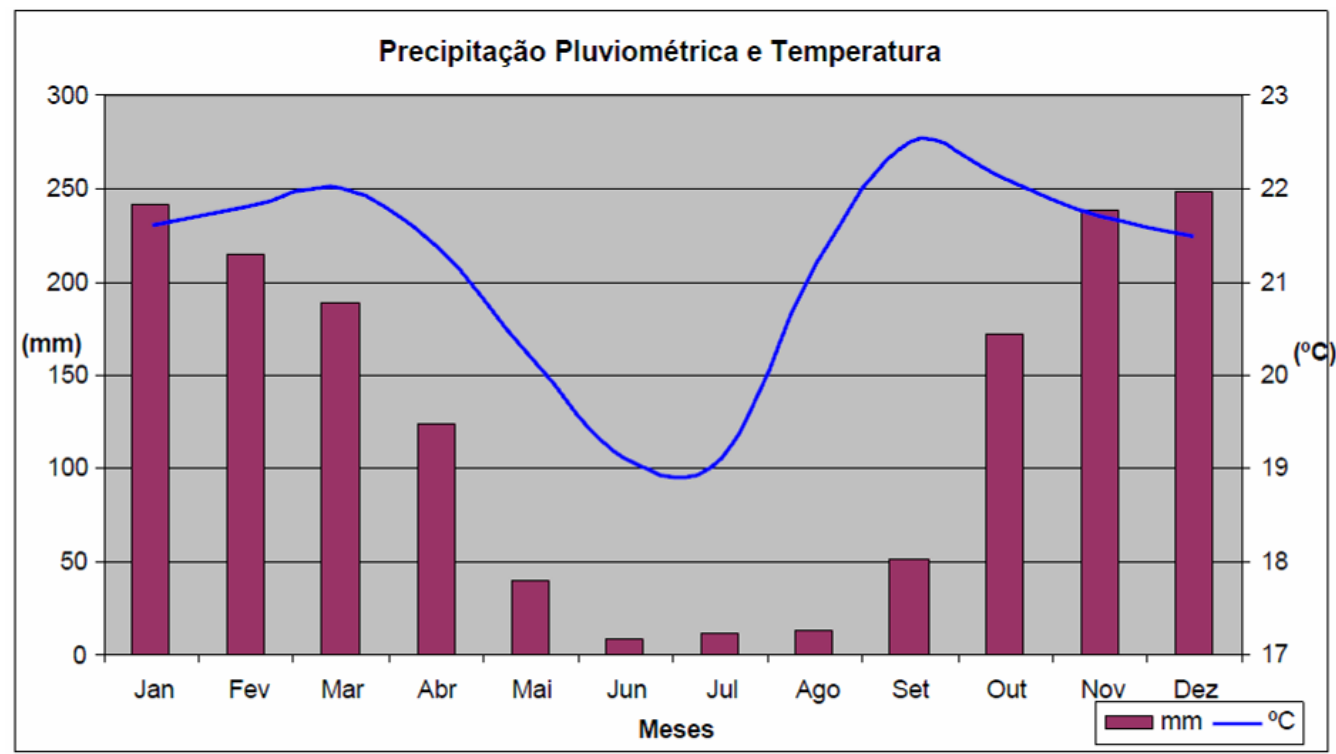

Figura 2.1 - Distribuição anual dos totais mensais de precipitação e temperatura da Estação Brasília nos períodos de 1963 a 1990 (Fonte: Baptista, 1998). 


\begin{tabular}{|c|c|c|c|c|c|c|c|c|c|c|c|c|}
\hline Mês & Jan. & Fev. & Mar. & Abr. & Mai. & Jun. & Jul. & Ago. & Set. & Out. & Nov. & Dez. \\
\hline $\begin{array}{c}\text { Total } \\
(\mathrm{mm})\end{array}$ & 241,4 & 214,7 & 188,9 & 123,8 & 39,3 & 8,8 & 11,8 & 12,8 & 51,9 & 172,1 & 238,0 & 248,6 \\
\hline
\end{tabular}

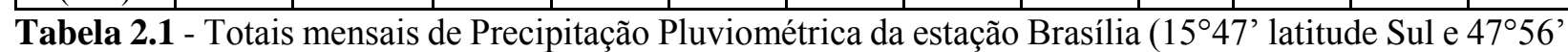
longitude Oeste).

Este regime de chuvas é favorável ao sistema de recarga proposto, pois a elevada concentração da precipitação resulta em amplo escoamento superficial nas épocas que concentram os eventos de maiores intensidade (ex.: $>25 \mathrm{~mm} / \mathrm{h}$ ).

Estimativas de Coimbra (1987) mostram que $12 \%$ da precipitação total infiltram na zona vadosa e efetivamente alcançam a zona saturada do aquífero.

O Mapa de Isoietas do Distrito Federal (Figura 2.2), confeccionado por meio do método de interpolação por Krigagem com dados de Estações Pluviométricas da CAESB, demonstra que a distribuição espacial das chuvas segue uma tendência decrescente de oeste para leste. Este mapa de isoietas foi confeccionado com dados de 42 estações localizadas no Distrito Federal e Entorno com no mínimo 15 anos de dados contínuos.

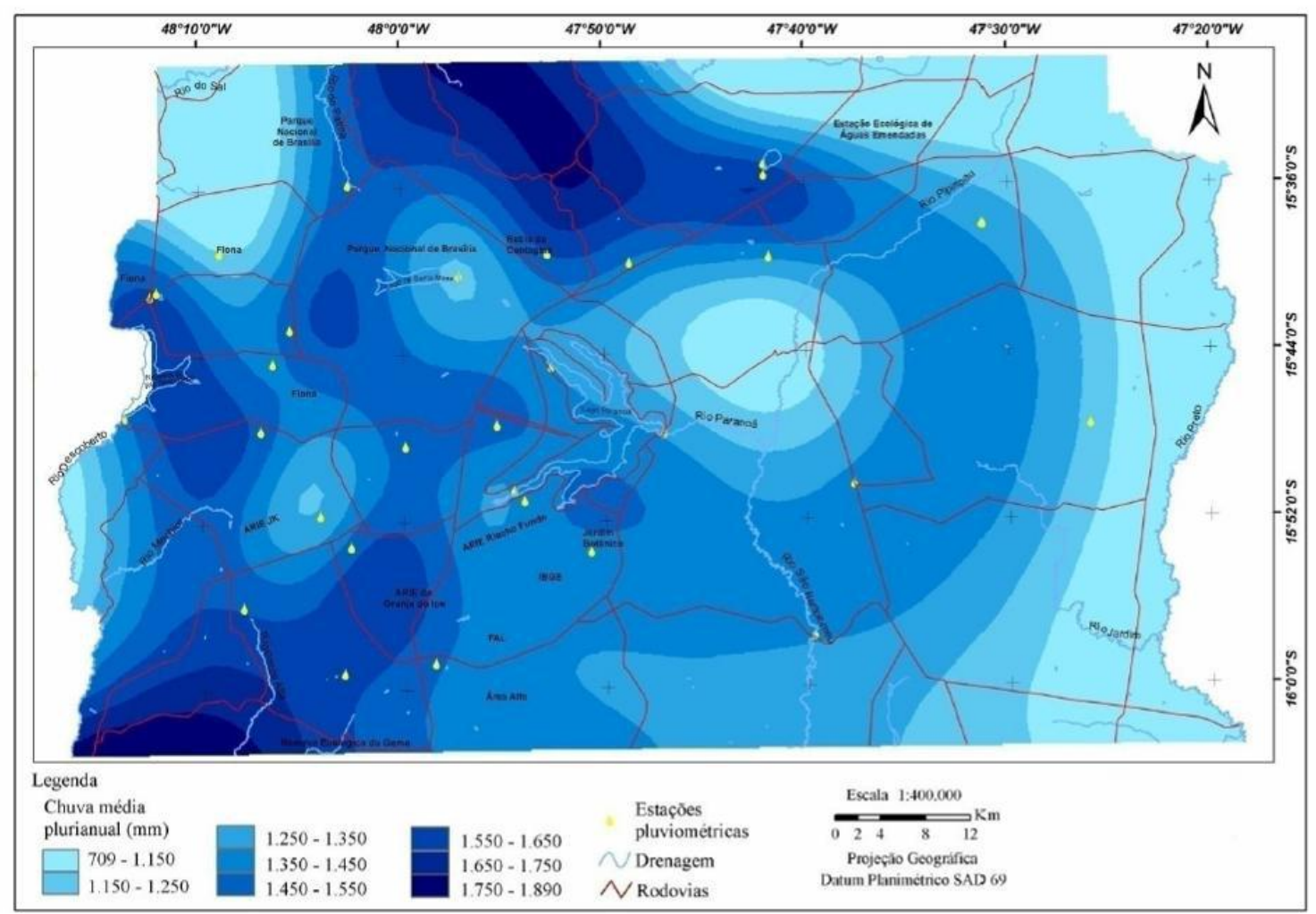

Figura 2.2 - Mapa de Isoietas do Distrito Federal (Fonte: Gonçalves, 2007. Disponível em: http://www.zeedf.com.br).

\subsection{2 - Geologia}

A geologia do Distrito Federal inclui os grupos Canastra e Paranoá de idade Mesoproterozoica e os grupos Bambuí e Araxá de idade Neoproterozoica. A distribuição espacial destas unidades é apresentada no mapa geológico do Distrito Federal (Figura 2.3). 
A geologia da área dos dois condomínios é representada pelo Grupo Paranoá que corresponde a uma sequência psamo-pelito-carbonatada exposta desde o Distrito Federal até o sul do Estado de Tocantins (Campos et al, 2013). No Condomínio San Diego ocorre o topo da Formação Ribeirão Contagem em contato com a Formação Córrego do Sansão. No Condomínio Privê o substrato é exclusivamente composto pela Formação Ribeirão do Torto.

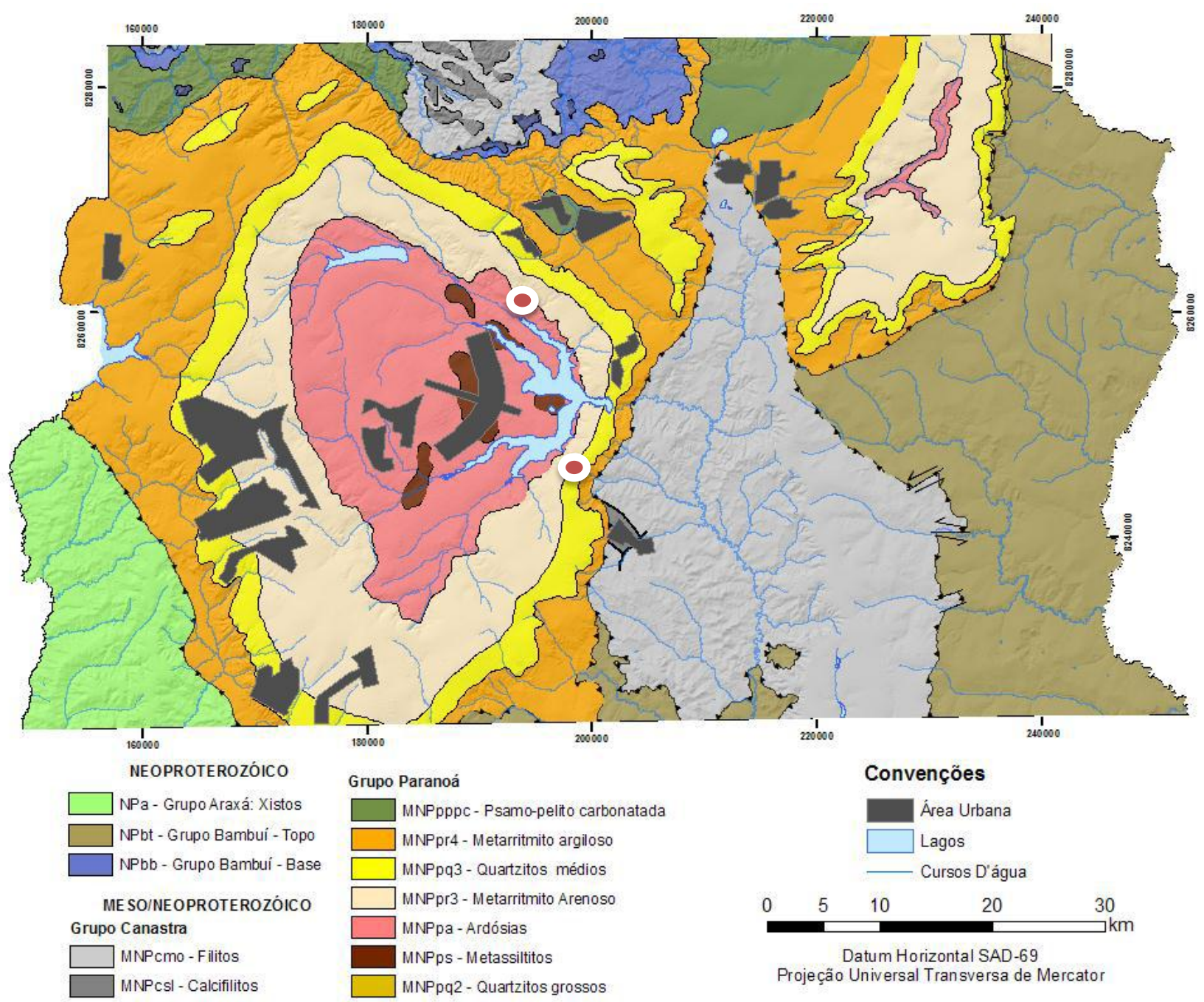

Figura 2.3 - Mapa geológico do Distrito Federal com destaque para a área em que foi instalado o sistema piloto de recarga artificial. Fonte: Atualizado de Freitas-Silva \& Campos, 1998.

Nesse contexto as rochas que compõem o substrato no Condomínio San Diego são representadas por quartzitos estratificados ou maciços, com frequentes intercalações de camadas de metassiltitos com espessuras variáveis de 20 a $80 \mathrm{~cm}$ em contato com metarritmitos ricos na fração argilosa. O primeiro tipo de rocha ocorre na maior parte da área, enquanto os metarritmitos apenas são expostos na parte baixa da área do condomínio. Nas áreas com exposições nas galerias de águas pluviais e demais escavações, os quartzitos apresentam tons claros (brancos ou beges Figura 2.4), enquanto os metarritmitos são rosados a avermelhados (Figura 2.5). Ou seja, o substrato geológico é constituído essencialmente por rochas arenosas com restrita contribuição argilosa. 
$\mathrm{Na}$ área do Condomínio Privê ocorrem ardósias com cores de alteração arroxeadas a rosadas sempre com duas clivagens ardosianas evidentes e intensamente fraturadas (Figura 2.6).

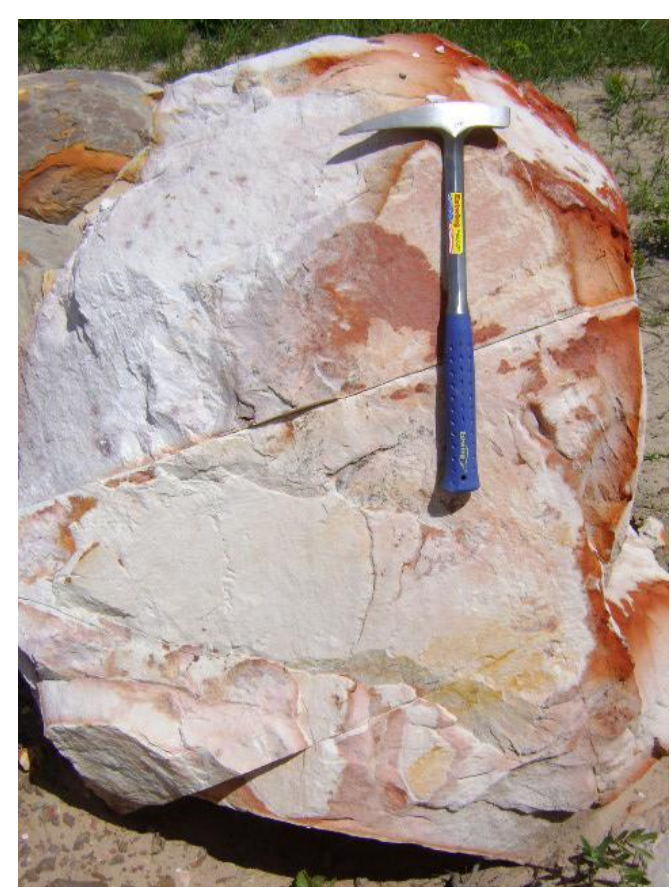

Figura 2.4 - Bloco de quartzito branco com manchas de oxidação, exposto a partir das obras de implantação de infraestrutura do Residencial Jardins do Lago, Quadra 1.

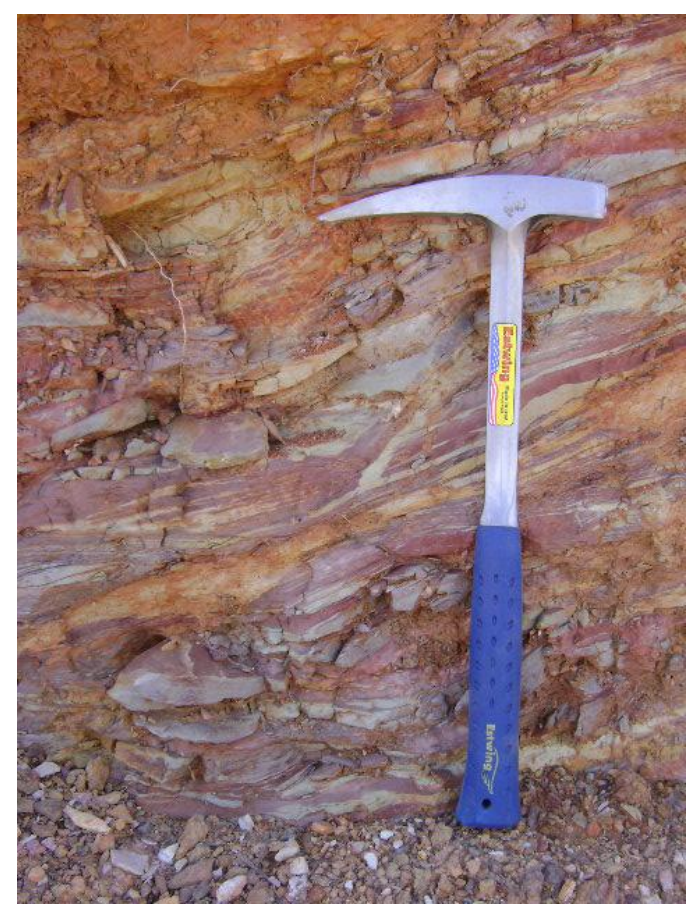

Figura 2.5 - Exposição de fácies pelítica de metarritmito arenoso, exposto próximo à área de instalação do sistema piloto de recarga artificial. 


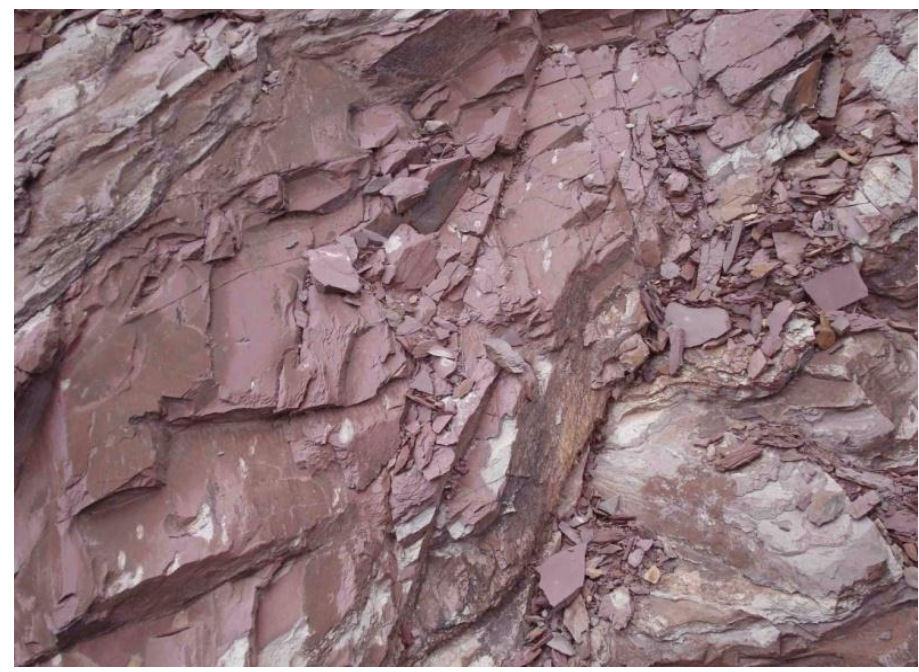

Figura 2.6 - Exposição de ardósia roxa da Formação Ribeirão do Torto do Grupo Paranoá que ocorre no Condomínio Privê Lago Norte.

\subsection{3 - Solos}

Os tipos pedológicos mais abundantes no DF são os Latossolos Vermelhos, Latossolos Vermelho-Amarelos e os Cambissolos Háplicos, cuja representatividade espacial se expressa em torno de 85\% (Figura 2.7) (Embrapa, 1978).

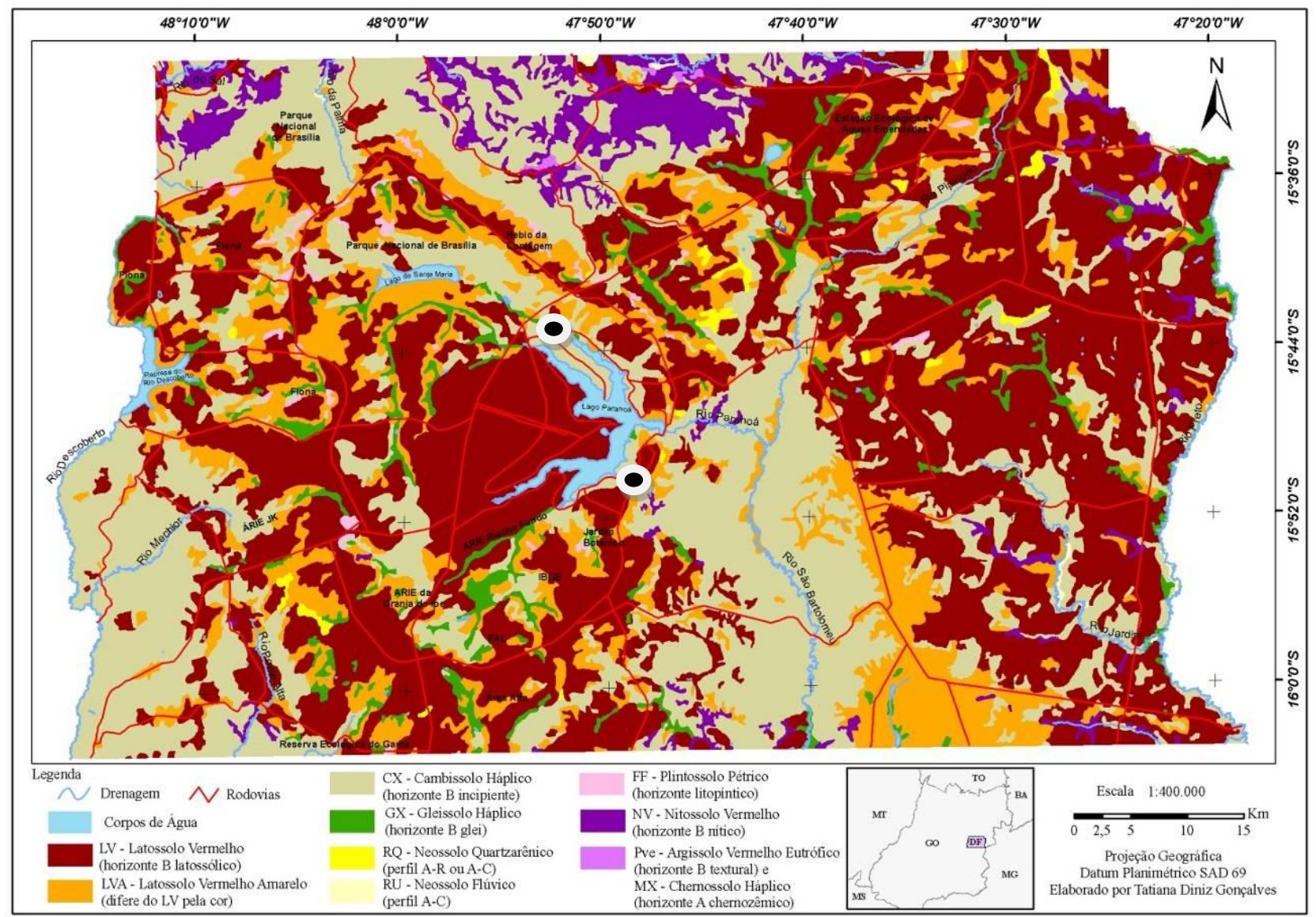

Figura 2.7 - Mapa de solos do Distrito Federal com destaque (círculos brancos) para a área em que foram instalados os sistemas pilotos de recarga artificial (Gonçalves 2006). 
Quanto à caracterização dos solos das áreas em questão, realizou-se no levantamento de campo a identificação e classificação táctil-visual expedita, com a finalidade de avaliar seu comportamento geral, sua classificação e sua permeabilidade.

No Condomínio San Diego os materiais presentes em superfície constituem-se de solos residuais, oriundos de processos de pedogênese in situ. Nos solos residuais, observa-se intenso processo de laterização que proporcionou a formação de solos lateríticos e solos saprolíticos. Foram identificados dois tipos principais de materiais:

$\checkmark$ Neossolo quartzarênico esbranquiçado a ocre, psamítico, desenvolvido in situ pela alteração de quartzitos médios. Ocupa a porção central e mais elevada da área. Apresenta permeabilidade variando de alta a muito alta.

$\checkmark$ Plintossolo litoplíntico concrecionário, poroso, desenvolvido a partir do intemperismo de metarritmitos. Este material ocupa a porção mais rebaixada do terreno. Apresenta permeabilidade moderada.

$\mathrm{Na}$ área do Condomínio Privê ocorrem solos de rasos a profundos. Como se trata de uma área com mais declividade foi observada a presença de aterros com espessuras consideráveis de até 1,5 metro. Três tipos de materiais se destacam:

$\checkmark$ Latossolos de textura argilosa que ocorrem na área mais plana e apresentam condutividade hidráulica moderada em função da estruturação grumosa presente;

$\checkmark$ Plintossolos concrecionários em que o horizonte plíntico apresenta cerca de $30 \mathrm{~cm}$. A permeabilidade é baixa, pois o material que ocorre na forma de matriz das concreções petroplínticas é argiloso;

$\checkmark$ Aterro representado por massa latossólica e cascalhos, que de forma geral foram compactados a rolo ou por meio de ferramentas manuais.

\subsection{4 - Relevo}

A compartimentação geomorfológica do território do Distrito Federal inclui as Regiões de Chapadas, Regiões de Dissecação Intermediária, Regiões Dissecadas de Vales, Regiões de Rebordo e Regiões de Escarpas (Novaes Pinto, 1994ab e Martins \& Baptista, 1998).

Recentemente Campos (2010) readequou os limites entre os compartimentos e sugeriu novos nomes para evitar interferência com termos utilizados na legislação, tendo propostos as seguintes denominações: Plano Elevado, Plano Intermediário, Vale Dissecado, Rebordo e Rampa Íngreme (Figura 2.8)

A área em questão, do Condomínio San Diego, está situada na borda leste de uma chapada cujo perfil é sustentado por rochas quartzíticas do Grupo Paranoá, com cotas topográficas superiores a 1000 metros e com padrão de relevo local plano. Para oeste (em direção ao vale do 
rio São Bartolomeu) a chapada dá lugar a uma superfície de dissecação de vale controlada por rochas mais argilosas, com maior densidade de drenagens e com cotas inferiores a 1000 metros. Este compartimento é genericamente denominado de Vale do São Bartolomeu.

A outra área de estudo, Condomínio Privê, está situada na região de Planos Intermédiários, exibe padrão de relevo plano a suave ondulado, baixa densidade de drenagem, ampla predominância de Latossolos, declividades inferiores a $12 \%$ e cotas entre 950 e $1.050 \mathrm{~m}$. A pedogênse supera a erosão e transporte no balanço morfodinâmico.

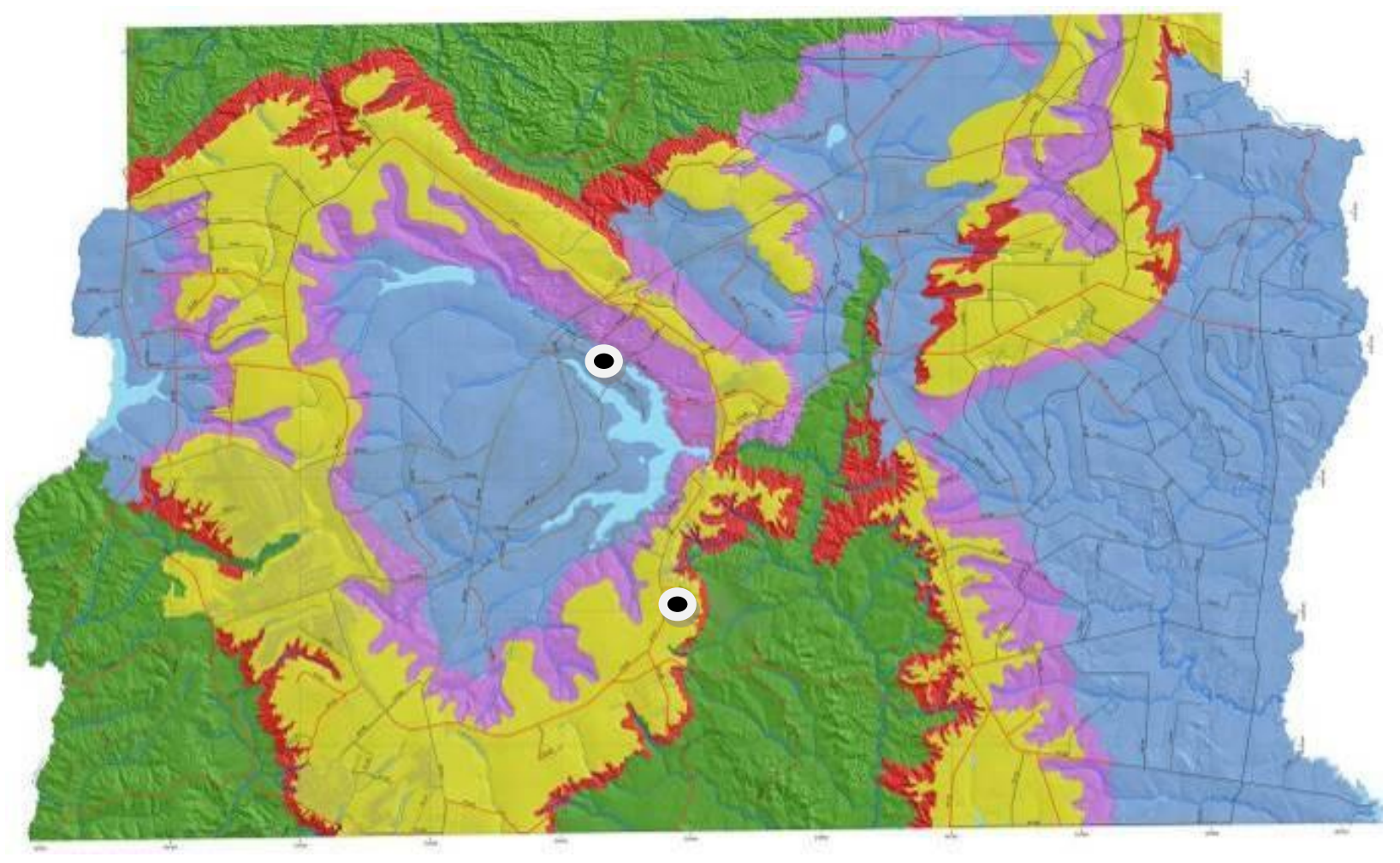

Figura 2.8 - Mapa geomorfológio do Distritro Federal. Em amarelo as áreas de Planos Elevados; em azul os Planos Intermediários; em verde o compartimento dos Vales Dissecados; em rosa Rebordos e em vermelho as Rampas Íngremes. Proposta de compartimentação geomorfológica do Distrito Federal.Fonte: Adaptado de Novaes Pinto, 1994 e Martins \& Baptista, 1998. Os círculos brancos representam os locais em que foram instalados os sistemas pilotos de recarga artificial.

\subsection{5 - Hidrogeologia}

No contexto geológico do Distrito Federal, caracterizado por rochas metamórficas, recobertas por espessos solos, podem ser diferenciados dois grandes grupos de aquíferos, o Domínio Aquífero Poroso e o Domínio Aquífero Fraturado. Os aquíferos do domínio poroso são caracterizados por meios geológicos não consolidados, como solos, manto de alteração das rochas (saprolito) e por materiais acumulados em calhas de drenagens (aluviões), com espessuras variando de poucos centímetros até $80 \mathrm{~m}$. Os aquíferos do domínio fraturado são caracterizados pelos meios rochosos, onde os espaços ocupados pela água são representados por descontinuidades 
planares, ou seja, planos de fraturas, microfraturas, diáclases, juntas, zonas de cisalhamento e falhas (Campos, 2004).

A área de estudo do Projeto Piloto I está inserida no contexto hidrogeológico que inclui o Domínio Poroso caracterizado pelo Sistema $\mathrm{P}_{1}$, com grande espessura $(<5 \mathrm{~m})$ e alta condutividade hidráulica e Domínio Fraturado caracterizado pelo Subsistema $\mathbf{R}_{\mathbf{3}} / \mathbf{Q}_{\mathbf{3}}$, Sistema Paranoá. A recarga dos aquíferos desse domínio se dá através do fluxo vertical e lateral de águas de infiltração a partir da precipitação pluviométrica. Constitui região de recarga natural regional da unidade hidrográfica do Ribeirão Taboca.

A mineralogia básica do subsistema $\mathbf{R}_{\mathbf{3}} / \mathbf{Q}_{\mathbf{3}}$ constitui-se de quartzo e filossilicatos, dentre os quais se destacam a ilita e finas lâminas de muscovita (Mizuno, 2012).

As águas subterrâneas desse domínio apresentam exposição à contaminação atenuada, uma vez que os aquíferos do Domínio Poroso sobrepostos funcionam como um filtro depurador natural, que age como um protetor da qualidade das águas mais profundas (Campos, 2004). Além da função filtro exercida pelo Domínio Intergranular podem-se citar ainda duas funções importantes dos aquíferos: a função armazenadora sendo diretamente vinculada aos volumes de água reservados nos meios geológicos e a função reguladora que está relacionada ao papel dos aquíferos como alimentadores da rede de drenagem superficial.

Os aquíferos intergranulares são recarregados diretamente por infiltração de águas de precipitação pluvial. Os aquíferos fraturados são recarregados a partir dos sistemas sobrepostos. $\mathrm{Na}$ área do Condomínio San Diego a relação entre estes dois domínios de águas subterrâneas, no sítio estudado, pode ser inserida no modelo conceitual de Única Superfície Potenciométrica sem Confinamento, em que existe uma região com fraturas abertas diretamente sob a seção de solo/saprolito que pode permanecer saturada no período das chuvas e secar na época de recessão das chuvas (Figura 2.9).

A descarga do aquífero freático se dá por exutórios do tipo nascentes de contato na interface entre os solos e a rocha alterada, onde há importante contraste de condutividade hidráulica. Além desta forma de descarga, o aquífero local também é rebaixado pelo bombeamento para abastecimento doméstico dos condomínios já consolidados presentes na região.

A área de estudo do Projeto Piloto II está inserida no contexto hidrogeológico que inclui o Domínio Intergranular caracterizado pelo Sistema P4, meio intergranular superficial representado por solos rasos (cambissolos e neossolos litólicos) e saprolitos relativamente espessos (até 20 metros), comumente desenvolvidos de rochas pelíticas. 


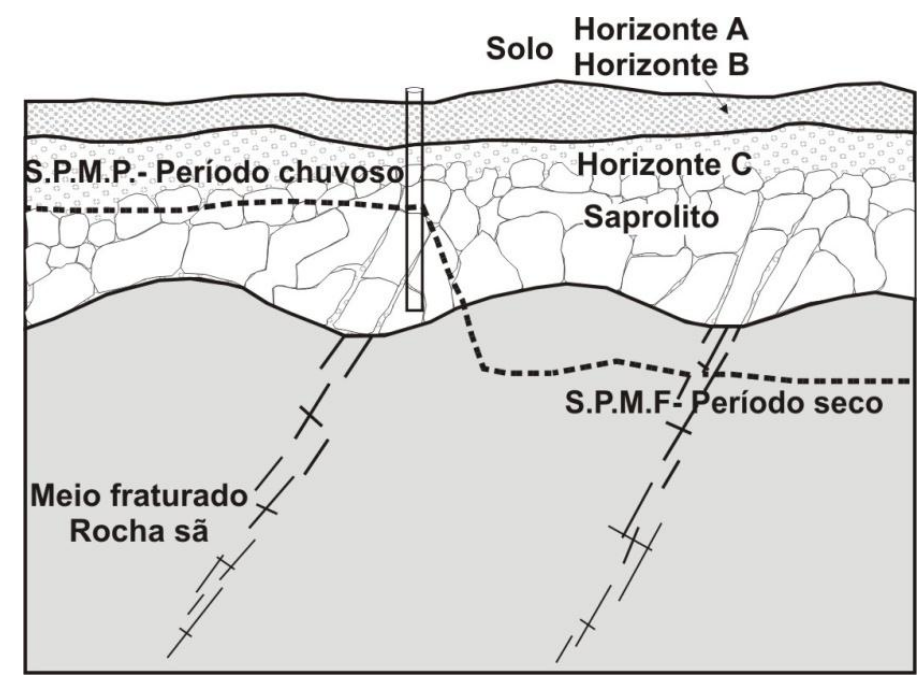

Figura 2.9 - Ilustração do Modelo de Única Superfície Potenciométrica sem confinamento. Nesse caso, o nível freático apresenta ampla oscilação anual e pode ser observado em solo ou rocha fresca. Condição comum quando ocorrem quartzitos em bordas de chapadas (Lousada \& Campos 2005).

No modelo conceitual de armazenamento e circulação de água subterrânea, Modelo de Única Superfície Potenciométrica com confinamento, também se considera a presença de dois meios de comportamentos distintos: aquíferos porosos recobrindo sistemas fraturados (Figura 2.10).

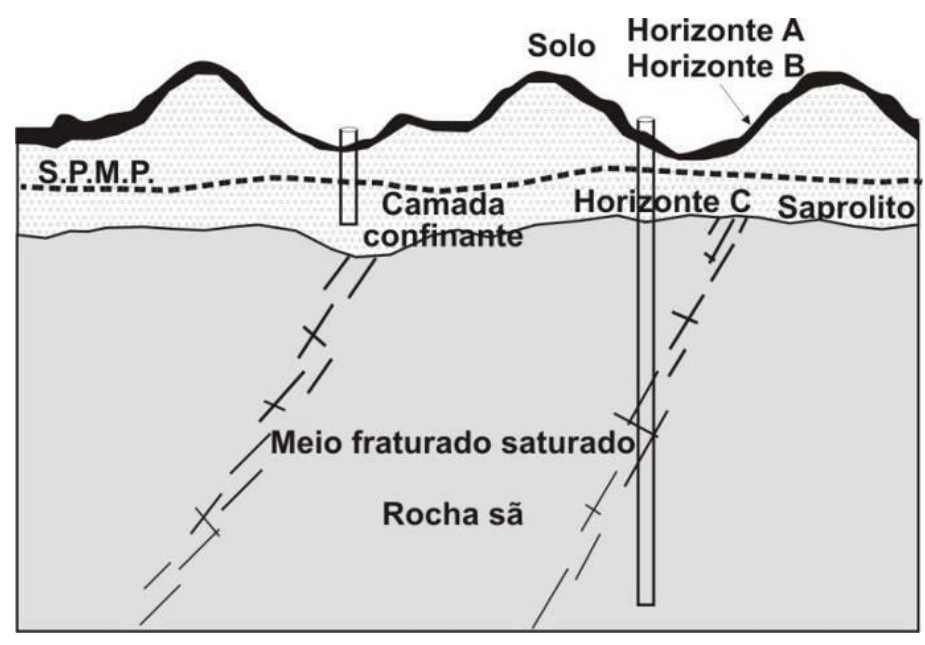

Figura 2.10 - Modelo de Única Superfície Potenciométrica com confinamento, onde a superfície de saturação permanece no meio aquífero intergranular superior. SPMP - superfície potenciométrica do meio poroso permanece coincidente com a superfície potenciométrica do meio fraturado (Lousada \& Campos 2005).

O aquífero superior é classificado como Sistema P4 (Campos \& Freitas-Silva 1998) e para esse caso específico, não apresenta zona de saturação, funcionando como camada confinante do tipo aquitarde.

O aquífero inferior tem comportamento de fluxo laminar em porosidade secundária planar, onde as águas armazenadas apresentam diferentes graus de confinamento. Dessa forma tais sistemas aquíferos fraturados têm comportamento artesiano, o que é corroborado pela presença de poços artesianos em situações de relevos mais movimentados. 
A recarga da água que alimenta as fraturas se dá pelo gotejamento a partir do aquitarde (Sistema P4) e ainda do fluxo lateral de águas infiltradas nas áreas planas e elevadas que se distribuem nas adjacências. Esse modelo de circulação mostra a importância das áreas de chapadas, planas e com solos espessos, para a regularização dos aquíferos fraturados da região dos cerrados.

Nas áreas onde a circulação nos aquíferos segue esse modelo de fluxo verificam-se, no período chuvoso, várias nascentes de contato e de depressão intermitentes. Esse fato mostra que as águas que infiltram pelo aquífero superficial são, em grande parte, descarregadas por fluxo interno e não contribuem efetivamente para a recarga das zonas de fraturas presentes em maiores profundidades.

\section{2 - FUNDAMENTAÇÃO TEÓRICA SOBRE RECARGA DE AQUÍFEROS}

Estudos realizados por Cadamuro (2002) apontam a recarga artificial como uma importante ferramenta para a gestão de recursos hídricos no Distrito Federal. Ainda segundo Cadamuro (2002), as condições climatológicas da região do DF favorecem a utilização da água da chuva para maximizar a recarga dos aquíferos fissurais locais. O sistema indireto de recarga artificial apresenta alta eficiência e baixo custo, com o uso da caixa de infiltração sem revestimento e preenchida por seixos de quartzo.

Técnicas de recarga artificial já foram testadas com sucesso em outras regiões como, por exemplo, Salo et al. (1986) nos Estados Unidos e Godoy et al. (1994) no Paraguai.

Esse referencial teórico apresenta uma revisão bibliográfica sobre recarga artificial de aquíferos com a descrição dos principais métodos de recarga artificial descritos na literatura e as principais publicações sobre o tema.

\subsection{1 - CONCEITOS}

Atualmente os recursos hídricos subterrâneos constituem uma fonte de abastecimento urbano, industrial e agrícola muito importante, mas a falta de gestão adequada que muitas vezes leva a sobrexplotação e a falta de políticas de ordenamento territorial podem comprometer a disponibilidade desses recursos bem como a sua qualidade.

A degradação dos mananciais superficiais e subterrâneos pela falta de políticas de zoneamento, planejamento e ordenamento territorial bem como a crescente demanda por água para os mais variados usos, exigem ferramentas técnicas de gestão que possam ampliar a disponibilidade dos recursos hídricos e sua qualidade.

A gestão dos recursos hídricos subterrâneos é extremamente importante para manutenção e regularização dos processos que integram o ciclo hidrológico e a recarga dos aquíferos constitui uma variável importante desse ciclo. 
A recarga subterrânea constitui ferramenta técnica de gestão muito eficiente e pode ser definida de forma geral como a quantidade de água que contribui para aumentar a reserva subterrânea, permanente ou temporária de um aquífero. Define-se como a quantidade de água que é acrescentada à zona saturada de água subterrânea. É resultante de um processo dinâmico da água que atinge a zona não saturada sob forças gravitacionais e potencial de umidade (Diamantino, 2005).

\subsection{2 - FORMAS DE RECARGA}

A recarga de aquíferos pode ocorrer de diversas formas: natural, artificial, facilitada, induzida e acidental (Diamantino, 2005). A seguir serão descritas essas formas de recarga:

\subsubsection{1 - Recarga Natural}

Toda a água existente no planeta Terra está em constante movimentação através do ciclo hidrológico (Figura 2.11). Neste ciclo são desenvolvidos processos como chuvas, infiltração da água nos solos, escoamento pela superfície, transpiração pelas plantas e alimentação de rios, córregos e nascentes, dentre outros (Fetter, 1994).

A recarga natural é um processo que consiste na infiltração das águas pluviais que serão posteriormente armazenadas no solo ou nos espaços vazios das rochas, sem intervenção humana. Alterações nas áreas de recarga como impermeabilizações e desmatamento afetam o processo de recarga natural e consequentemente o ciclo hidrológico.

No ciclo hidrológico, a água da precipitação pode cair diretamente na superfície terrestre e infiltrar-se. A água que se infiltra no solo fica sujeita à evaporação, pode ser absorvida pelas plantas sendo posteriormente evapotranspirada, ou pode escoar em profundidade em direção à zona saturada subsuperficial; esta última é a água de recarga (Roseiro, 2009).

A recarga natural dos aquíferos dá-se em áreas sob sua influência e que combinem dois fatores fundamentais: a disponibilidade de água; seja oriunda de precipitação pluviométrica ou de corpos d'água superficiais; e a presença de formações geológicas que permitam a infiltração e transporte subterrâneo da água (ex. solos arenosos, fraturas) (Moura, 2004). 


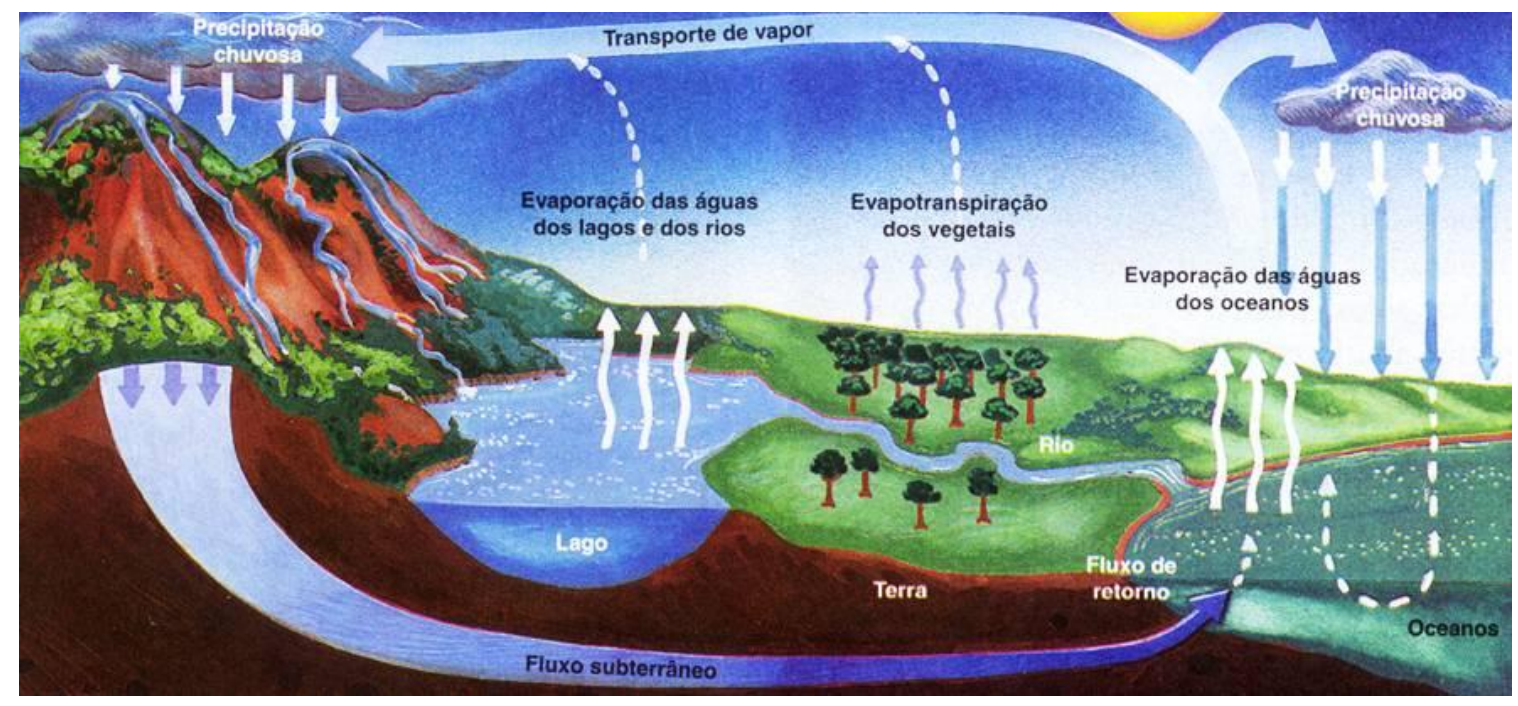

Figura 2.11 - O ciclo hidrológico com destaque para os principais processos responsáveis pela circulação da água da atmosfera para a superfície e subsuperfície e novamente para a atmosfera (Fonte: http://nd.water.usgs.gov/).

\subsubsection{2 - Recarga Artificial}

A água subterrânea não está distribuída de forma homogênea no planeta. Em alguns locais, em função do clima e de características geológicas, há disponibilidade desse recurso e em outros não. Para minimizar os efeitos da dependência desses fatores e da sobrexplotação, a recarga artificial é muito utilizada em diferentes localidades do mundo.

A água utilizada em recarga pode ter diferentes origens: águas residuais de estações de tratamento, água dessalinizada, água de corpos hídricos superficiais e água da chuva recolhida dos telhados de casas.

A recarga artificial pode ser praticada, a princípio, em qualquer tipo de formação permeável que tenha condições de armazenar e transmitir água. Pode ser definida como uma atividade planejada cujo objetivo principal consiste em aumentar a quantidade de água subterrânea disponível, através da construção de infraestruturas projetadas para aumentar a recarga natural, ou para facilitar a percolação das águas superficiais ou para introduzir diretamente a água no aquífero através de furos de injeção (Diaz et al., 2000 e Diamantino, 2005).

Fetter (1994) define que a recarga artificial consiste de qualquer processo que induza infiltração ou injeção de água nos aquíferos, seja ela planejada ou não.

Roseiro (2009) define a recarga artificial de aquíferos como sendo o armazenamento de excedentes hídricos em meio subterrâneo nos períodos de maior disponibilidade para serem utilizados em períodos de seca ou escassez.

Dillon (2005) considera que a recarga artificial é uma ferramenta importante para a gestão de aquíferos, constituindo a forma mais barata para o abastecimento de pequenos aglomerados populacionais e constitui a solução viável para alcançar os objetivos do Milênio decretado pelas 
Nações Unidas, no ano 2000, no tocante à água potável acessível a todas as pessoas, principalmente em zonas semiáridas e áridas.

Um dos principais objetivos da recarga artificial consiste em aumentar a disponibilidade dos recursos hídricos subterrâneos, mas pode ser utilizada para outros fins como, por exemplo, para o controle da intrusão salina em aquíferos costeiros, armazenamento de água, redução da subsidência dos solos, melhoria da qualidade da água através da remoção de sólidos suspensos pela filtração pelo solo ou através da diluição por mistura com as águas subterrâneas existentes.

A maioria dos trabalhos desenvolvidos sobre recarga artificial tem como propósito a ampliação das reservas hídricas. O presente trabalho tem como objetivo com a recarga artificial melhorar a qualidade da água de aquíferos contaminados no Distrito Federal, a partir da diluição/tratamento in situ das águas subterrâneas.

\section{Métodos de Recarga Artificial}

Um dos principais fatores que vão influenciar na escolha do método de recarga artificial mais adequado para determinado local está relacionado ao conhecimento do mecanismo de recarga natural. Outros fatores importantes como clima, tipo de solo e rocha, índices pluviométricos, relevo, origem da água, uso e ocupação do solo, aspectos legais e econômicos também devem ser considerados.

Considerando os tipos de aquíferos a serem recarregados, a metodologia pode variar de recarga direta por infiltração no solo, mais adequada para aquíferos livres (freáticos) ou indireta por meio de furos que atinjam o aquífero, mais adequada para os confinados profundos.

Os métodos de recarga à superfície por infiltração no solo (direta) consistem em permitir a infiltração das águas através de uma extensa superfície de contato entre a água e o solo. Os métodos indiretos de recarga consistem na introdução de água no aquífero através de furos ou poços.

Díaz et al. (2000) afirmam que os métodos utilizados para as operações de recarga dividemse em: recarga à superfície e recarga em profundidade. Os métodos de recarga à superfície podem ser aplicados ou não no leito dos rios. Os primeiros incluem as represas, as sarjas e os canais permeáveis; os segundos incluem as balsas, as valas, os canais e os terrenos extensos. Os métodos de recarga em profundidade incluem os furos de injeção, as grandes cavidades profundas no solo, os drenos e galerias e as valas e sondagens.

Gale et al. (2002) afirmam que a recarga artificial de aquíferos pode realizar-se, em termos gerais, do seguinte modo: (1) à superfície do solo facilitando a infiltração da água através de bacias, canais, valas, etc, (2) na zona não saturada do solo colocando a água de recarga em valas de infiltração, poços ou furos, ou (3) diretamente no aquífero recorrendo à injeção da água. Estes sistemas de recarga podem agrupar-se nas seguintes categorias: (1) Métodos de alagamento à 
superfície; (2) Poços e furos abertos; (3) Furos e sondagens; (4) Barreira de infiltração; (5) Represas de armazenamento de areia; (6) Captação de água da chuva em telhados.

Gale \& Dillon (2005) dividem os métodos de recarga artificial em (1) Métodos de espalhamento (bacias de infiltração, Soil Aquifer Treatment (SAT), inundações controladas, recarga incidental por irrigação); (2) Métodos que provocam modificações no leito de rios (bacias de percolação a jusante de açudes de controle, represas de armazenamento de areia, açudes subsuperficiais, açudes permeáveis); (3) Furos de injeção, furos de injeção e recuperação (Aquifer Storage and Recovery - ASR) e poços; (4) Barreira de infiltração (induced bank infiltration e interdune-filtration); (5) Captação de água da chuva (rainwater harvesting).

SEWRPC (2006) classifica os métodos de recarga artificial de aquíferos em infiltração superficial por intermédio de bacias de infiltração; infiltração subsuperficial por intermédio de furos ou valas na zona não saturada do solo; (3) recarga direta por intermédio de furos de injeção, que também podem ser de recuperação; (4) recarga facilitada através de alterações na superfície do solo que aumentam a recarga nas zonas naturais; (5) infiltração riverbank que inclui recarga induzida, que utiliza campos de poços nas proximidades de cursos de água os quais induzem a recarga do escoamento superficial para o aquífero; (6) water banking no qual um aquífero é recarregado através de um dos métodos anteriores para recuperação futura.

Bouwer (2002) refere, de forma simplificada, apenas a quatro tipos de sistemas de recarga artificial: (1) infiltração superficial; (2) infiltração na zona não saturada; (3) poços; (4) sistemas de recarga combinados.

Fetter (1994) afirma que a recarga artificial pode ser realizada através de caixas ou barragens de infiltração, espalhamento de água sobre o solo, sulcos paralelos às curvas de nível, poços de injeção, dentre outros.

A seguir serão descritos os diversos sistemas de recarga artificial segundo propostas de Diamantino (2005):

\section{Métodos de Recarga Artificial em Superfície}

São métodos que consistem essencialmente em permitir a infiltração da água através de uma extensa superfície de contato entre a água e o solo. São normalmente utilizados em aquíferos freáticos, que não possuem níveis de baixa permeabilidade à superfície do solo ou na zona não saturada do aquífero, através da qual se pretende que a água de recarga se infiltre e atinja a zona saturada (Diamantino, 2005). 


\section{Métodos de Recarga em Superfície fora do Leito dos Rios}

Constituem as bacias de infiltração/recarga, represas perenes, valas/canais/balsas e os sistemas de recarga por alagamento e irrigação.

\section{Bacias de infiltração/recarga}

Este é o método mais simples, antigo e amplamente utilizado para executar a recarga artificial dos aquíferos, pois se baseia na simples infiltração da água destinada à recarga. O método é preferido por permitir o uso eficiente do espaço e requerer uma manutenção simples e rápida, sendo sua utilização indicada para áreas que disponham de topografia favorável e solos que apresentem moderada a elevada condutividade hidráulica (Moura, 2004).

São bacias rasas escavadas no solo para permitir a infiltração da água. Para garantir a eficiência desse método são condições necessárias: a presença de solo permeável e zona não saturada sem camadas impermeáveis, presença de aquífero livre e ausência de zonas contaminadas. Quando se utilizam efluentes ou mesmo água de baixa qualidade esses sistemas funcionam como sistemas de recarga e de tratamento (Figura 2.12).

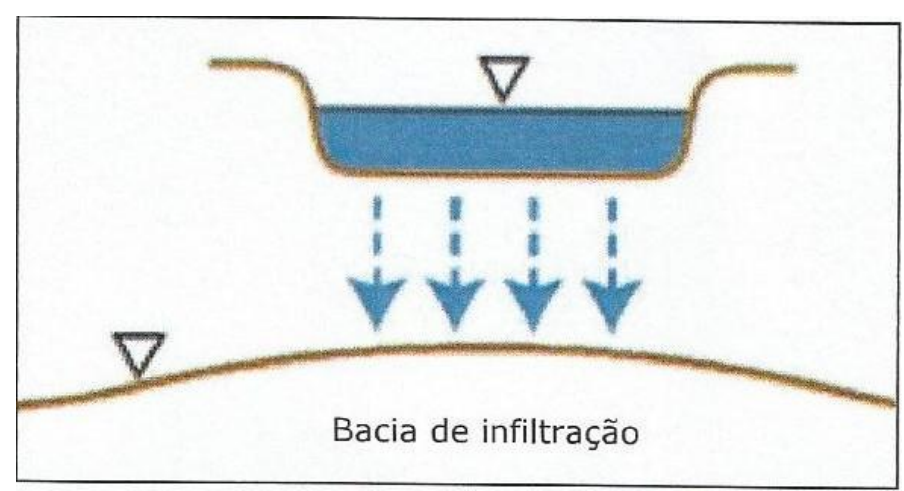

Figura 2.12 - Esquema simplificado de uma bacia de infiltração (extraído de Gale \& Dillon, 2005).

\section{Represas Perenes}

São sistemas que armazenam grande quantidade de água a diferentes profundidades podendo ser utilizados como fonte de água para irrigação direta e para aumentar a recarga de aquíferos. São sistemas que podem funcionar como estruturas de recarga ou de armazenamento (Figura 2.13). 


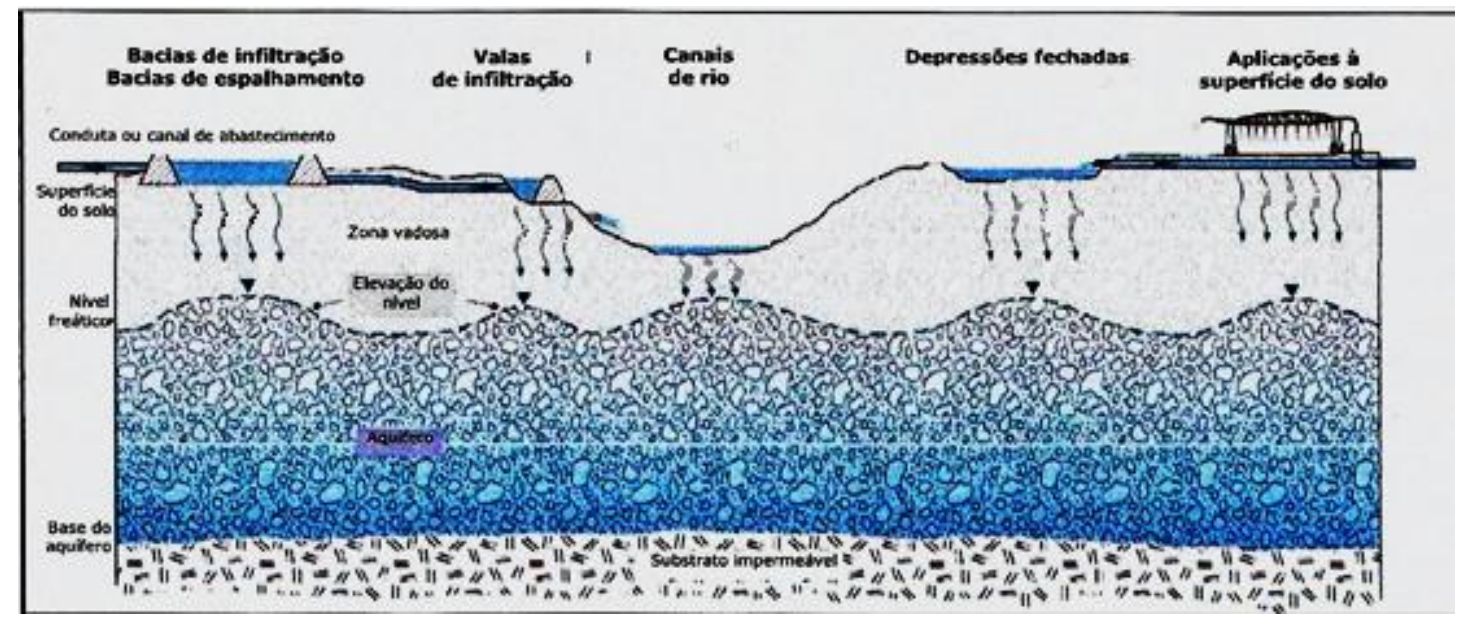

Figura 2.13 - Exemplos de métodos de recarga à superfície (Topper et al., 2004 in SEWRPC, 2006).

\section{Valas, Canais e Balsas}

Os canais e valas de infiltração são mecanismos construídos principalmente para aproveitar o excedente hídrico de um rio ou córrego (Figura 2.14). São barreiras hidráulicas que direcionam a água para sistemas de canais e valas de recarga, aproveitando a topografia do terreno (Almeida, 2011). São também sistemas alternativos quando não existe disponibilidade de terreno suficiente para a construção de bacias de infiltração (SEWRPC, 2006). Uma vala pode ser descrita como uma trincheira longa e estreita, sendo a sua largura inferior à sua profundidade.

As valas de infiltração também podem ser construídas em áreas urbanas, sob calçadas, avenidas ou estacionamentos. Pequenas obras de captação de água de chuva através de coberturas de edificações residenciais/comerciais podem ser realizadas, com direcionamento destas águas para valas rasas (Almeida, 2011).

\section{Sistemas de Recarga por Alagamento}

A partir de canais, a água é desviada de rios e descarregada em área plana, cercada por valas para evitar inundação. Forma-se uma fina camada de água sobre a superfície do solo com velocidade mínima de escoamento. São necessárias grandes áreas de terreno para desenvolvimento dessa operação de recarga. Entretanto, importante carga de sedimentos pode ser transportada pela água e depositada na superfície prejudicando as taxas de infiltração. Este método é menos dispendioso do que outros. 


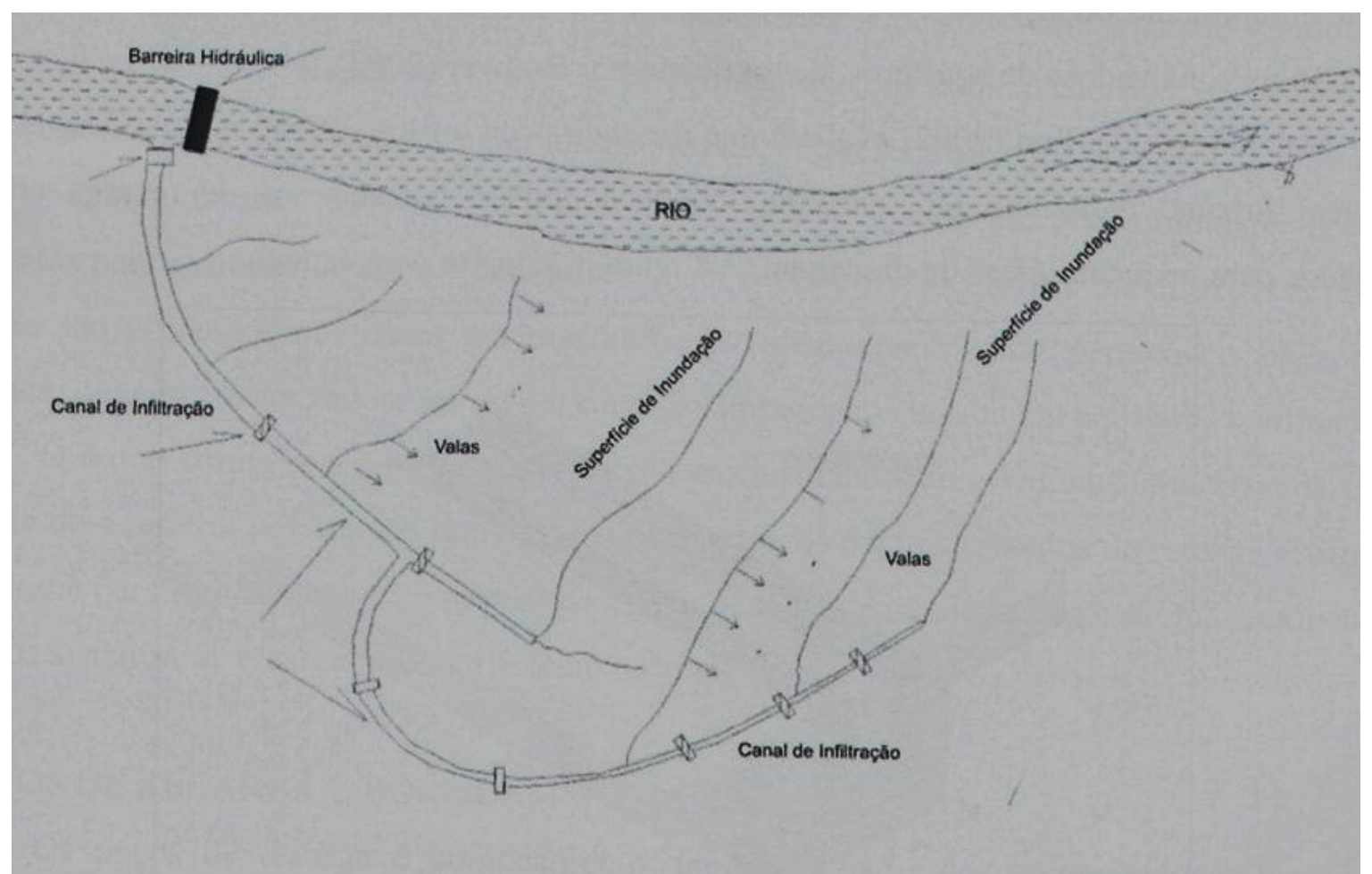

Figura 2.14 - Recarga em planície de inundação com valas e canais de desvio (extraído de ALMEIDA, 2011).

\section{Sistemas de Recarga por Irrigação}

Diaz et al. (2000) designa por "terrenos extensos" um tipo de sistema de recarga que consiste na descarga de água numa grande superfície do terreno, geralmente através da aplicação de irrigação com vazões elevadas. Neste tipo de recarga não existem custos adicionais para a preparação do terreno uma vez que já está instalado no local um sistema de distribuição da água. Normalmente a irrigação desenvolve-se em zonas planas onde o nível da água se encontra pouco profundo, o que implica um volume pequeno disponível para o armazenamento de água no aquífero. Os esquemas de irrigação são frequentemente uma forma de recarga não intencional de aquíferos, por exemplo, em zonas áridas e semiáridas onde a percolação profunda se baseia essencialmente na lixiviação de sais a partir da zona das raízes das plantas (Gale et al., 2002).

\section{Método Artificial de Recarga em Superfície Dentro do Leito dos Rios}

São métodos de recarga artificial implantados dentro do leito dos rios.

\section{Represas de Armazenamento de Areia}

São represas de armazenamento de areia (Figura 2.15) construídas em rios efêmeros e vales bem definidos e encaixados. São mais adequadas em locais de terreno irregular e em condições climáticas áridas, onde o escoamento superficial ocorre, normalmente, sob a forma de cheia. A 
parede da represa é construída de uma margem a outra do rio, no leito do rio de modo a abrandar as águas de cheias ou de eventos de escoamento temporários. Isto permite a deposição do material mais grosso e a sua acumulação na porção anterior da parede da represa. Esta parede pode ser subida após cada evento de cheia, sendo a sua altura que determina o volume do escoamento e a quantidade de material acumulado. Com o tempo, os sucessivos eventos de escoamento acabam por construir um aquífero artificial que permite a infiltração da água em vez do seu escoamento natural pelo rio. A água armazenada fica assim disponível para extração, no entanto, quando estas represas se constroem em cima de materiais permeáveis a água acumulada acaba também por recarregar o aquífero subjacente.

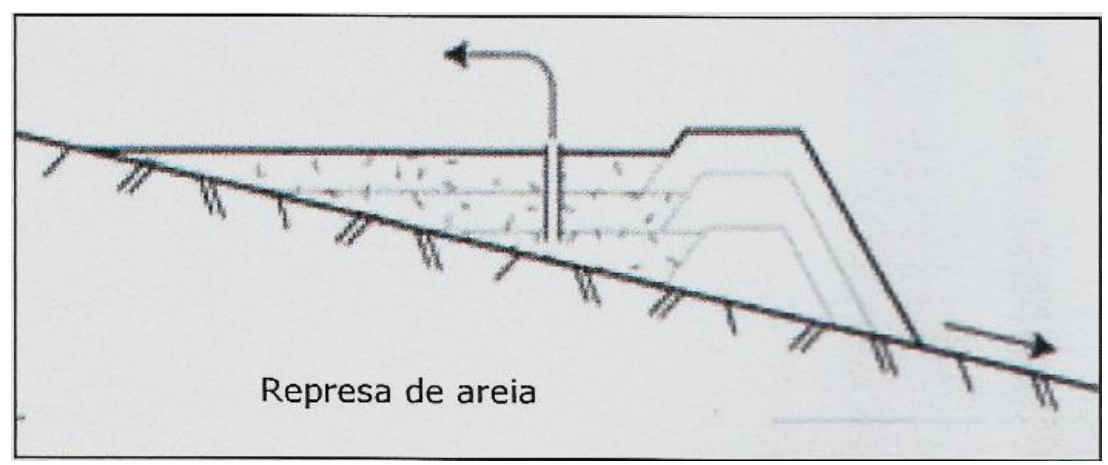

Figura 2.15-Esquema Simplificado de uma represa de armazenamento de areia implantada no leito de rios (extraído de Gale \& Dillon, 2005).

\section{Modificação no Canal de um Rio}

Consiste na construção de barreiras ou represas (Figura 2.16) em série no leito do rio, utilizando os sedimentos aluvionares do próprio rio. Essas barreiras diminuem a energia de escoamento da água durante os episódios torrenciais, possibilitam a infiltração no solo e reduzem a erosão e o transporte de sedimentos.

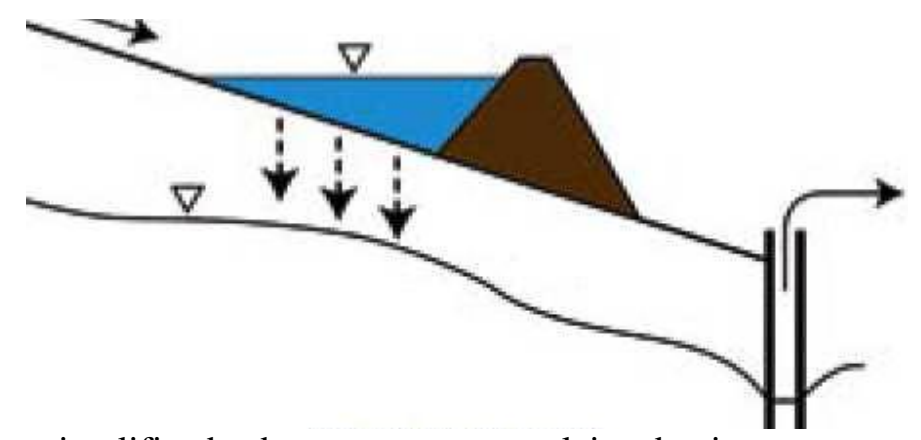

Figura 2.16 - Esquema simplificado de uma represa no leito do rio e pequena bacia de percolação a montante (extraído de Gale \& Dillon, 2005).

\section{Represas com Descarga}

As represas com descarga são estruturas construídas no leito dos rios para melhorar a infiltração da água que escoa com velocidade muito elevada, retém parte da energia do escoamento torrencial promovendo a deposição dos sedimentos suspensos e o controle da descarga da água 
para infiltração a jusante (Figura 2.17).

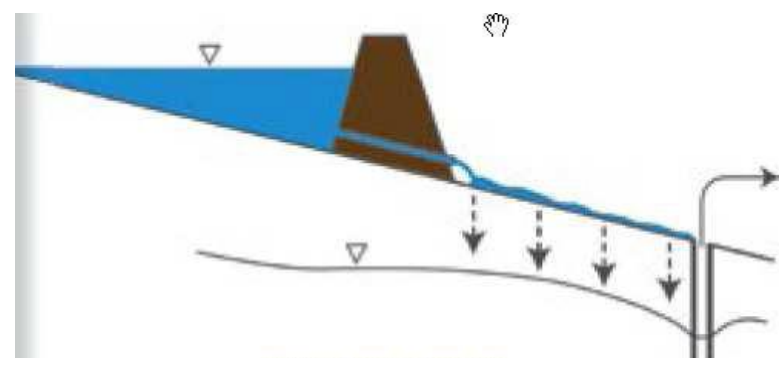

Figura 2.17 - Esquema simplificado de uma represa no leito do rio com zona de descarga (extraído de Gale $\&$ Dillon, 2005).

\section{Barreiras ou Represas Subterrâneas}

São barreiras ou represas subterrâneas (Figura 2.18) construídas até atingir a base do aquífero subjacente ao leito do rio para reter o escoamento natural da água. São estruturas preenchidas por materiais de natureza impermeável e seladas. A recuperação da água infiltrada nestes sistemas é feita pela extração em furos próximos (Roseiro, 2009).

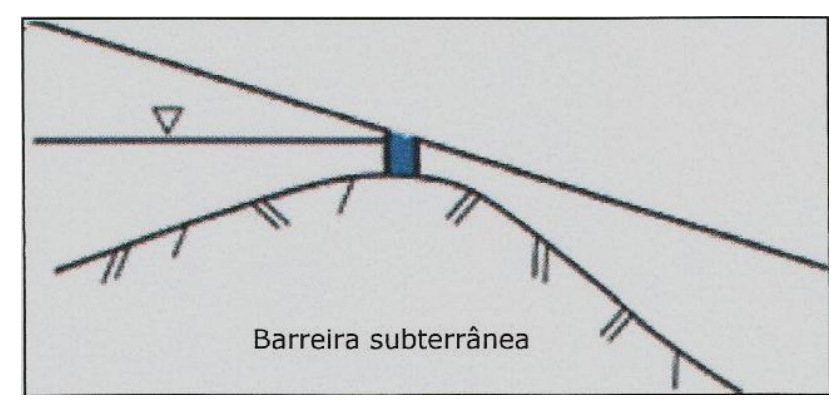

Figura 2.18 - Esquema simplificado de uma Barreira subterrânea no leito de um rio (extraído de Gale \& Dillon, 2005).

\section{Método de recarga artificial na zona não saturada}

Recentemente surgiram novos métodos de recarga artificial de aquíferos que se utilizam na recarga de aquíferos livres, nomeadamente os poços na zona não saturada ou dry wells, as trincheiras e galerias de infiltração, os reservatórios de infiltração (infiltration shafts e infiltration pits) e os aquíferos artificiais (Roseiro, 2009).

A recarga indireta que consiste na captação de água de chuva em telhados (Fig. 2.19) com sua condução até valas e caixas de infiltração é considerada um método de recarga artificial em zona não saturada. 


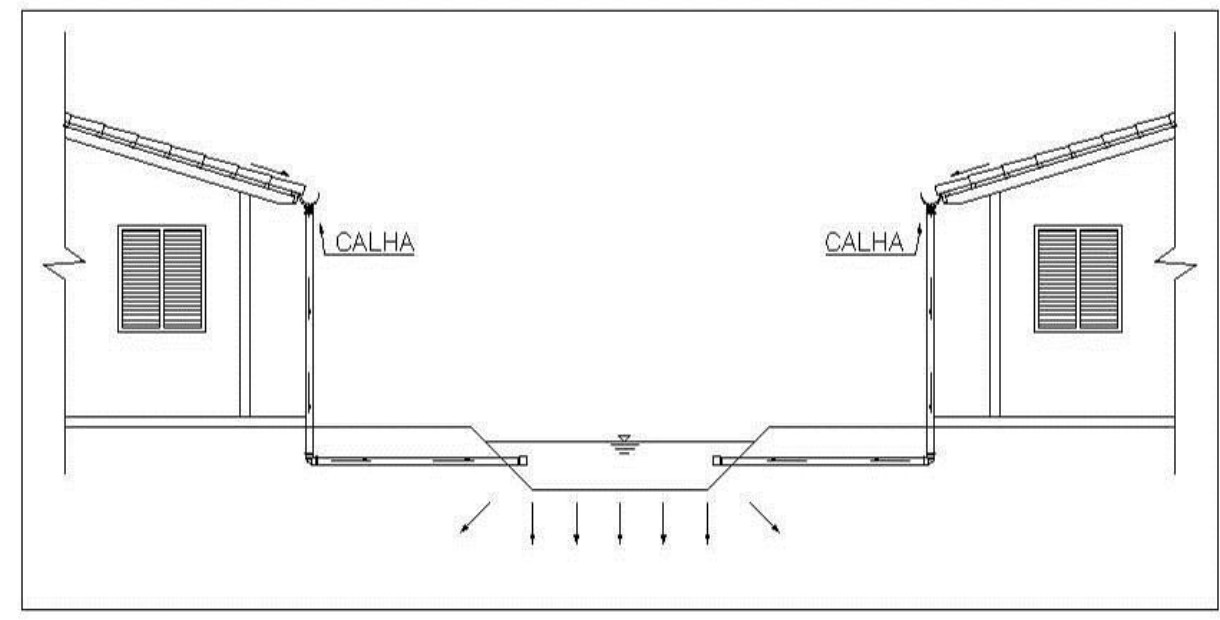

Figura 2.19 - Valas de infiltração, com uso de água de chuva captada em telhados.

Os métodos de recarga artificial na zona não saturada do solo são utilizados quando os solos de cobertura não são favoráveis à infiltração da água ou quando não existe um espaço disponível (Figura 2.20). São normalmente utilizadas valas, poços, furos ou outros tipos de escavações que permitam a passagem da água pelos níveis superficiais mais impermeáveis, níveis suspensos ou níveis confinantes na zona não saturada e a sua posterior colocação na zona não saturada para infiltração até ao aquífero (adaptado de SEWRPC, 2006).

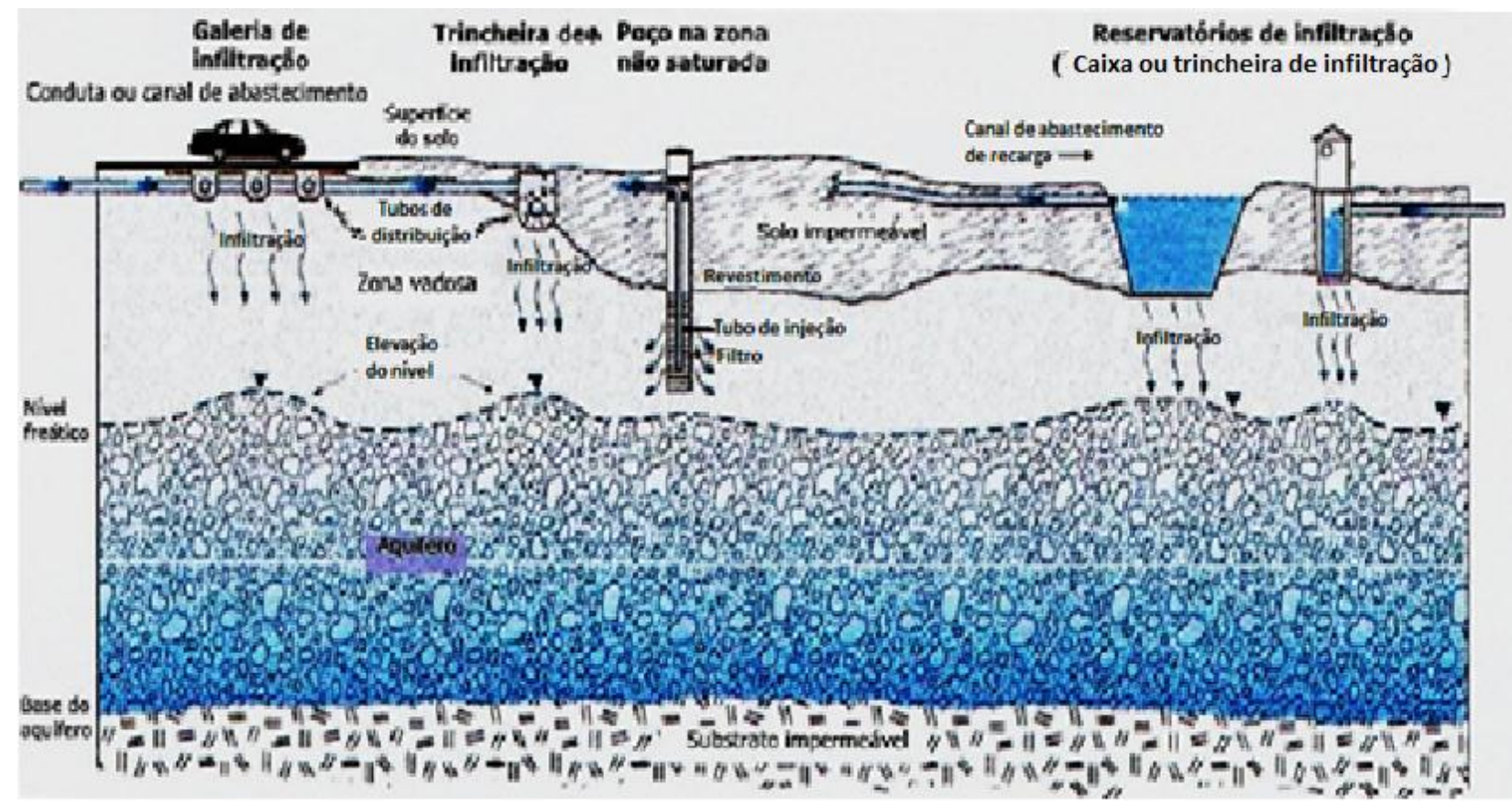

Figura 2.20 - Exemplos de métodos de recarga artificial em profundidade, na zona não saturada (Topper et al., 2004 in SEWRPC, 2006).

\section{Poços na Zona Não Saturada}

De acordo com Diaz et al. (2000) esses poços são perfurações com cerca de 10 a 50 metros de profundidade destinados à recarga de aquíferos freáticos. Quando o nível freático se encontra a 
grande profundidade a utilização deste tipo de poços é mais econômica do que a utilização de poços de injeção, mas é preciso que penetrem uma seção adequada nos níveis permeáveis para que a recarga aconteça de forma apropriada.

\section{Trincheiras de Infiltração}

São sistemas de recarga econômicos, se comparados aos poços na zona não saturada, e podem ser utilizados quando os níveis permeáveis são rasos, mas os solos de cobertura tem baixa permeabilidade.

As trincheiras são escavações alargadas com um metro de largura e cerca de dez metros de profundidade (Díaz et al., 2000). São preenchidas por areia grossa ou cascalho fino que funcionam como filtro.

\section{Aquíferos Artificiais}

De acordo com Roseiro (2009) os aquíferos artificiais são essencialmente filtros de areia que se destinam à recarga do aquífero ou ao tratamento de águas de má qualidade. Estes sistemas de recarga ou de tratamento são construídos pela escavação de um poço, com cerca de 2 metros de profundidade, que são preenchidos com areia ou outro material permeável. O revestimento lateralmente é feito com material plástico e o fundo coberto com um nível de cascalho ou de tubos drenantes.

\section{Métodos de Recarga Artificial em Profundidade}

Consistem na introdução de água no aquífero, geralmente através de poços. Eles são amplamente utilizados em regioes onde o substrato é formado por alternância de níveis permeável e impermeável.

\section{Poços de Injeção}

Os poços de injeção ou de recarga são os sistemas de recarga artificial em profundidade mais utilizados através dos quais se injeta água no aquífero (Figura 2.21). São utilizados nos casos em que os terrenos apresentam elevado custo ou a sua ocupação restringe a aplicação de outros métodos de recarga (Diaz et al., 2000).

Os poços de injeção são construídos até alcançar a zona saturada do aquífero e permitem a injeção direta da água na zona saturada. Estes poços minimizam o tempo necessário à passagem da água de recarga através da zona não saturada, apresentam alta taxa de recarga e evitam as reações, por vezes adversas, entre a água e os solos ou minerais existentes na zona não saturada e podem ser perfurados verticalmente, radialmente ou horizontalmente, de acordo com a tecnologia selecionada (SEWRPC, 2006). 


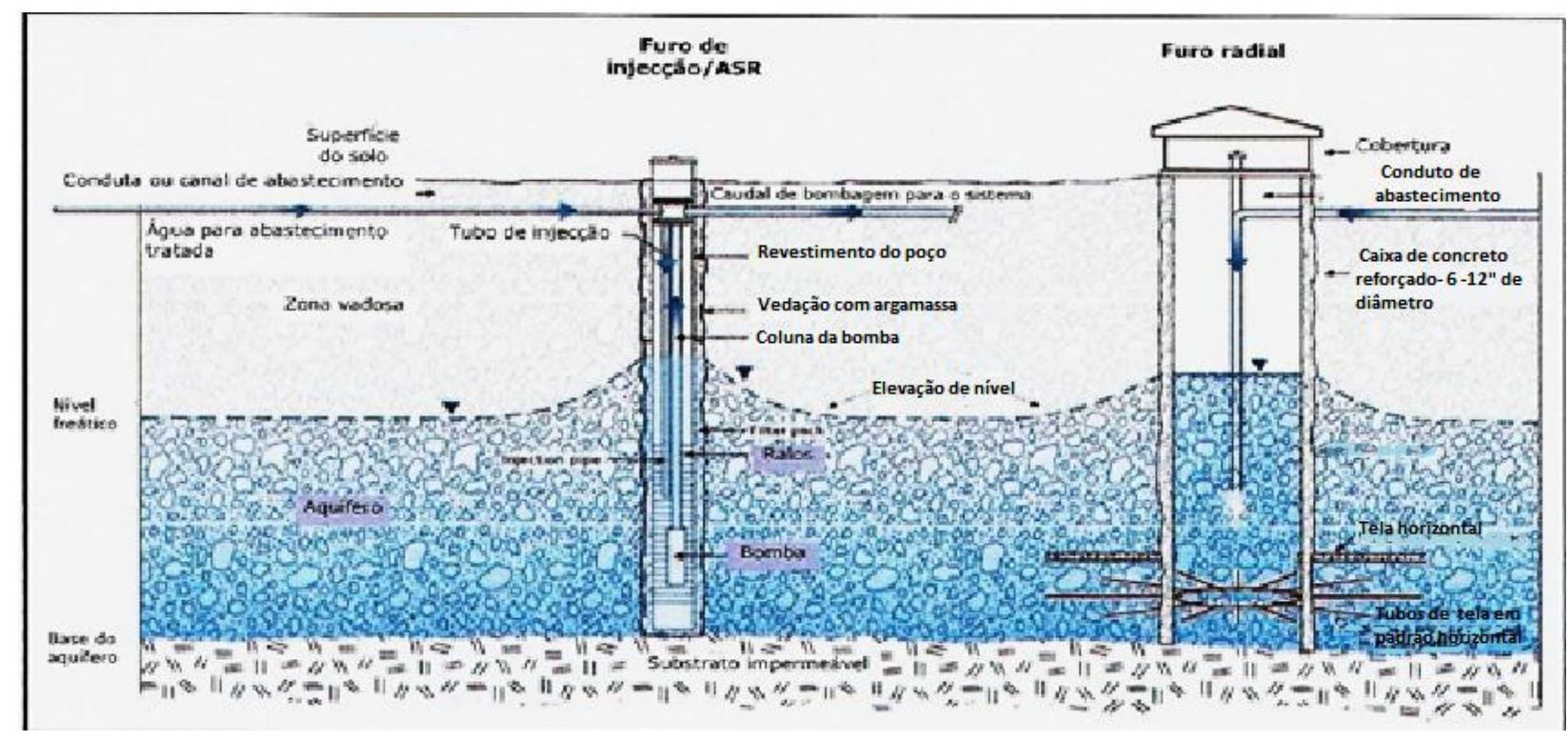

Figura 2.21 - Esquema de métodos de injeção direta (Topper et al., 2004 in SEWRPC, 2006).

\section{Poços de Armazenamento Subterrâneo e de Extração}

Os poços de recarga e bombeamento, também conhecidos como Aquifer Storage and Recovery-ASR (Figura 2.22a), são muito utilizados em diversas partes do mundo. A grande vantagem dos poços $A S R$ é a possibilidade de recarga do aquífero, em períodos de excedentes hídricos e bombeamento, em períodos de escassez (Almeida, 2011).

Roseiro (2009) considera poços $A S R$ como uma variante dos poços de injeção já que funcionam para injeção, mas também para extração. Outra variante são os poços de injeção, transferência e recuperação. Nestes casos a água é injetada num poço e recuperada noutro, posicionado a uma determinada distância do primeiro, de modo a aumentar o tempo de circulação da água através do aquífero, beneficiando da capacidade de purificação/tratamento da água de recarga. Esta tecnologia tem a terminologia de Aquifer Storage Transfer and Recovery (ASTR) (Gale \& Dillon, 2005). Nestes sistemas o poço de injeção e o de extração são poços independentes (Figura 2.22b).

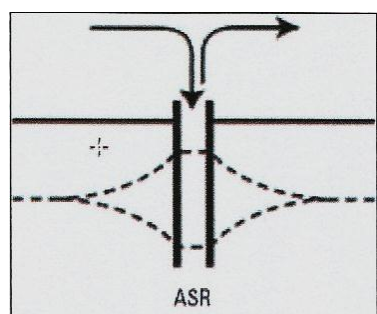

a)

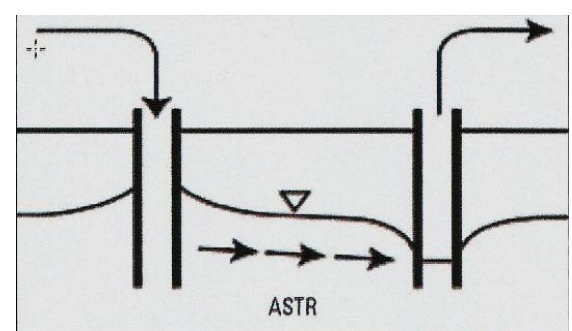

b)

Figura 2.22 - a) Ilustração esquemática de recarga no sistemas Aquifer Storage and Recovery (ASR) e b) Aquifer Storage Transfer and Recovery (ASTR) 


\section{Grandes Cavidades Profundas no Solo (Dolinas)}

Consiste em aproveitar simas e dolinas (Figura 2.23) de terreno calcáreos para introduzir água no aquífero (Diaz et al., 2000)

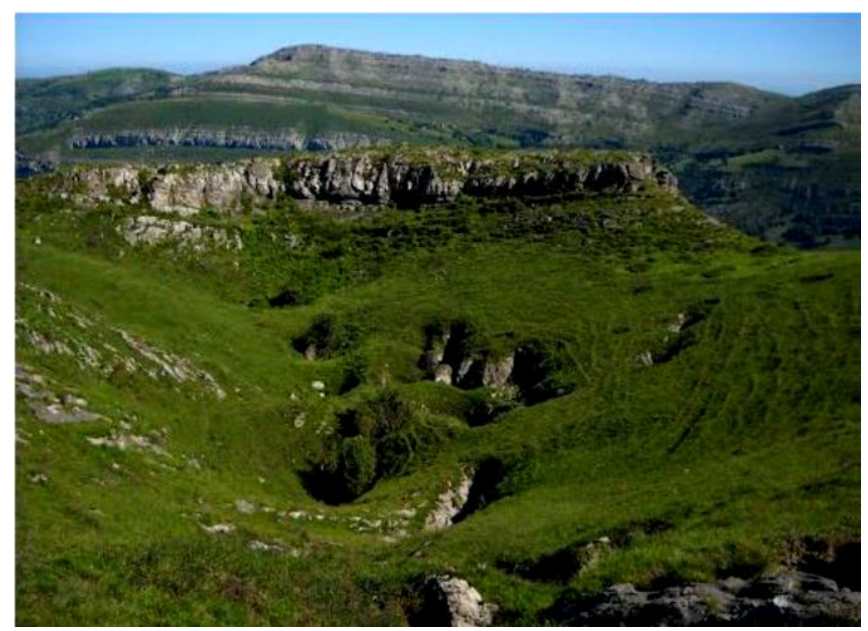

Figura 2.23 - Injeção em dolinas como exemplo de recarga em profundidade. Fonte: www.panoramio.com/photo/68707856 (in Monteiro, 2013).

\section{Tratamento Solo-Aquífero - TSA}

Consiste na recarga efetuada em instalações superficiais de infiltração, tais como bacias ou canais de infiltração utilizando águas servidas em locais onde condições hidrogeológicas permitem obter níveis de tratamento consideráveis, devido ao movimento dos efluentes através do solo, camada não saturada e no próprio aquífero. Este é o sistema designado Tratamento Solo Aquífero, ou TSA, que vem sendo empregado com sucesso em diversas partes do mundo (Região do Dan em Israel, Chipre, Estados Unidos nos Estados de Arizona, Califórnia, Nevada, etc.) (Hespanhol, 2002).

Aquíferos e sua zona não saturada sobreposta também tem um potencial de autolimpeza que pode ser utilizado como uma fase final de tratamento de águas de baixa qualidade, como águas residuais domésticas. As águas de superfície, águas pluviais ou recuperadas de esgoto que de outra forma seriam perdidas por escoamento superficial ou descarga podem ser temporariamente armazenadas em reservatórios de água subterrânea equilibrando, assim, a variabilidade na disponibilidade de recursos com a demanda (Kloppmann, 2009).

Hespanhol (2002) relata que a infiltração e percolação de efluentes tratados se beneficiam da capacidade natural de biodegradação e filtração dos solos, proporcionando um tratamento in situ e permitindo, em função do tipo de efluente considerado, dos métodos de recarga, de condições hidrogeológicas e dos usos previstos, eliminar a necessidade de sistemas de tratamento avançados.

Em Israel se opera um novo sistema de gestão de aquíferos no âmbito do Projeto da Região de Dan, um dos maiores e mais antigos sistema de tratamento de solos aquífero do mundo que usa águas residuais tratadas para recarga do aquífero. As águas servidas coletadas na região consistem 
de $90 \%$ de esgoto doméstico e $10 \%$ de esgoto industrial. Após o pré-tratamento com seletores anaeróbicos e aeração ativada do lodo, os efluentes são recarregados dentro do aquífero através do Sistema de Tratamento de Solos Aquíferos (TSA) com um tempo de retenção de 6-12 meses. Dados desse sistema para reuso agrícola comprovam a elevada eficiência na remoção de compostos e íons específicos, prejudiciais às culturas irrigadas com as águas bombeadas do aquífero, alimentado artificialmente com esgotos tratados (Hespanhol, 2002 e Kloppmann, 2009).

A utilização do tratamento de solos aquíferos em longo prazo precisa de uma profunda compreensão dos processos biogeoquímicos subjacentes, a fim de limitar o risco para os diferentes usos e alcançar a sustentabilidade em termos de qualidade da água (Kloppmann, 2009).

Os custos associados aos sistemas TSA são, em média $40 \%$ inferiores a dos sistemas de tratamento convencionais equivalentes, operando na superfície (Hespanhol, 2002).

Hespanhol (2003) enumera algumas condições hidrogeológicas favoráveis para permitir a recarga artificial de efluentes domésticos tratados através do sistema TSA. As condições consideradas ideais são associadas aos seguintes fatores:

- Solos permeáveis com taxas de infiltração moderadas a elevadas;

- Camada não saturada com espessura suficiente para estocar o volume de recarga necessário;

- Ausência de camadas impermeáveis que causem excessiva acumulação dos volumes infiltrados antes de atingir a zona saturada do aquífero;

- Distribuição granulométrica na camada não saturada superior que suporte a prática do sistema TSA;

- Coeficientes de transmissividade que não causem retenção excessiva de água no aquífero;

- Aquífero não confinado.

\subsubsection{3 - Recarga Facilitada}

Consiste em promover medidas que melhorem a capacidade de infiltração do solo, tais como: 1) substituir as plantas de raízes profundas por plantas com raízes mais superficiais, diminuindo dessa forma as perdas por evapotranspiração, 2) dar preferência a plantas com folhagem que interceptem menos as águas da chuva, 3) adotar medidas de acumulação e conservação da água no solo, 4) remover o material argiloso que se deposita no solo e 5) rebaixar o nível piezométrico pela explotação do aquífero mais superficial.

A variação sazonal do nível piezométrico ou o rebaixamento causado pelo bombeamento determinam o espaço disponível no aquífero para o armazenamento subterrâneo e desta forma também controlam os volumes possíveis de recarga.

\subsubsection{4 - Recarga Induzida}

São sistemas de recarga designados barreiras de infiltração. Consistem na execução de furos 
próximos de cursos d'água, com o objetivo de que uma maior quantidade de água do rio recarregue o aquífero subjacente, à medida que se provoca o rebaixamento no aquífero através desses furos.

\subsubsection{5 - Recarga Acidental}

A recarga pode ocorrer de forma acidental quando através de fossas sépticas não impermeabilizadas, aterros sanitários, campos agrícolas excessivamente irrigados e rupturas de sistemas de abastecimento de água e de captação de esgoto, efluentes líquidos alcançam a zona vadosa e saturada dos aquíferos (Barbosa et al., 2008).

\subsection{3 - APLICAÇÕES DA TÉCNICA DE RECARGA ARTIFICIAL DE AQUÍFEROS NO MUNDO}

Almeida (2011) relata que os primeiros usos de recarga artificial de aquíferos provavelmente remontam às comunidades antigas, principalmente em regiões de clima árido, com longos períodos secos, onde a necessidade de acúmulo de água em raros períodos chuvosos era de extrema importância para o abastecimento das populações.

A recarga artificial tem sido desenvolvida e experimentada em vários países por todo o mundo e considerada, nos últimos anos, como sendo uma importante ferramenta para gestão dos recursos hídricos subterrâneos. A recarga artificial foi e é utilizada em mais de 32 estados americanos e 26 países (Topper et al., 2004 in SEWRPC, 2006). Segundo Weeks (2002, in SEWRPC, 2006) os Serviços Geológicos dos Estados Unidos da América estão envolvidos nestes projetos há mais de 100 anos, tendo sido a maioria de recarga artificial de aquífero realizada nas regiões áridas e semiáridas do oeste ou em regiões onde o aumento da população e a agricultura provocaram escassez de água, como na Califórnia, Arizona, Nevada, Flórida, Kansas, Colorado, New Jersey e New York (Asce, 2001 in SEWRPC, 2006 e Monteiro, 2013).

As práticas de recarga artificial são bastante utilizadas em várias regiões do mundo com objetivos variados como mostram os seguintes exemplos: Fresno, Califórnia (Salo et al. 1986), visando minimizar contaminação de aquíferos; Las Vegas Valley, Nevada (Katzer \& Brothers 1989), objetivando aumentar a água disponível para abastecimento público; Filadélfia, Paraguai (Godoy et al. 1994), com o intuito de aumentar o volume de água para irrigação; Orange County, Califórnia (Matthews, 1991), para recarregar aquíferos com água de rio; Alemanha, para a regularização da temperatura e $\mathrm{pH}$, a partir de águas tratadas com origem variada; Karany, República Checa (Knezek \& Kubala 1994), para viabilizar o abastecimento público da Cidade de Praga; e Norte de Londres, Inglaterra (O’Shea 1994), para gestão de áreas semiáridas.

Berger \& Gientke (1998) descrevem modelos de barragens construídas para captação de água e recarga artificial de aquíferos no litoral da Califórnia para conter o avanço da intrusão marinha, 
ocasionada pela superexplotação dos aquíferos desde os anos de 1940.

$\mathrm{Na}$ América do Sul as técnicas de recarga são pouco difundidas e, raros são os exemplos de sistemas de recarga artificial que envolvem grandes volumes de infiltração. Na região da Filadélfia, no Chaco Paraguaio, existe um sistema de recarga por caixas escavadas diretamente na zona não saturada do aquífero (tajamares), que recebem o fluxo superficial e otimizam a recarga em uma região em que a água subterrânea é naturalmente muito salinizada (Godoy et al. 1994).

Os aspectos relativos à recarga artificial têm sido discutidos em literatura diversa na qual se destacam as publicadas nos simpósios realizados no âmbito do tema, nomeadamente nos Proceedings of International Recharge Symposium realizados na Califórnia em 1988, na Flórida em 1994, em Amsterdam em 1998, em Adelaide em 2002, em Berlim em 2005, em Phoenix, em 2007 e Abu Dhabi em 2010 (Roseiro, 2009 e Almeida, 2011).

A literatura disponível sobre este tema é vasta, destacando-se as seguintes publicações: Bouwer (2002) descreve os passos necessários para planejar, projetar, construir, manter, operar e concluir um projeto de recarga artificial de águas subterrâneas no artigo Artificial recharge of groundwater: hydrogeology and engineering publicado no Hydrogeology Journal. Relata que a recarga artificial de águas subterrâneas é alcançada introduzindo água de superfície em bacias, sulcos, valas, ou outras instalações onde se infiltra no solo e se move para baixo para recarregar os aquíferos. É cada vez mais utilizada para o armazenamento subterrâneo de curto ou de longo prazo, onde tem várias vantagens sobre o armazenamento de superfície, e na reutilização da água. Requer solos superficiais permeáveis e onde estes não estão disponíveis, valas ou poços na zona insaturada podem ser usados, ou a água pode ser injetada diretamente em aquíferos através de poços.

Para projetar um sistema de recarga artificial de águas subterrâneas, as taxas de infiltração do solo, a permeabilidade adequada e ausência de áreas poluídas da zona não saturada entre a superfície do solo e do aquífero devem ser observadas. $\mathrm{O}$ aquífero deve ser suficientemente transmissível para evitar o acúmulo excessivo de água subterrânea. O conhecimento dessas condições requer investigações de campo e, se nada for detecado, bacias de teste devem ser implantadas para prever o desempenho do sistema. Questões de qualidade da água devem ser avaliadas, especialmente no que diz respeito à colmatação em fundos de bacias ou outras superfícies de infiltração, bem como as reações geoquímicas no aquífero.

ASCE (2001) publicou Standard Guidelines for Artificial Recharge of Ground Water (34-01)(Diretrizes padrão para recarga artificial de águas subterrâneas - no qual são descritos os passos necessários para planejar, projetar, construir, manter, operar e concluir um projeto de recarga artificial de águas subterrâneas. A recarga pode ser realizada tanto através da aplicação de água à superfície do solo por infiltração ou diretamente em aquíferos através de poços. Esta norma 
também descreve as considerações econômicas, ambientais e legais, incluindo os direitos à água, leis e regulamentos, bem como investigação de campo e procedimentos de testes que podem ser aplicáveis. As orientações abrangem situações que podem ocorrer em diferentes tipos de projetos e podem ser aplicadas a projetos básicos ou pequenos, selecionando as porções dessas orientações que são apropriadas para o projeto proposto. Esta pesquisa foi conduzida por Ivan Johnson da ASCE/EWRI (American Society of Civil Engineers/Environmental and Water Resources Institute) e documenta o estado dos locais de investigação e operação de tecnologias de recarga artificial em 2001.

Gale et al. (2002) com o objetivo de auxiliar na tomada de decisões fundamentadas na importância da recarga artificial para o abastecimento de zonas rurais e, em projetos de gestão das águas subterrâneas, coordenou o Projeto AGRAR - "Augmented Groundwater Resources by Artificial Recharge", criado pelo British Department for International Development (BDID) e liderado pelo British Geological Survey (BGS), em colaboração com outras organizações, iniciouse em Julho de 2002 e terminou em Julho de 2005. A preocupação era com a sustentabilidade dos recursos hídricos subterrâneos, principal fonte de abastecimento nas zonas rurais para irrigação e uso doméstico em muitos países em desenvolvimento e o aumento da explotação.

Em uma primeira fase do projeto foi feita uma revisão das metodologias e controle de eficiências, procurando identificar benefícios, restrições e incertezas associados à recarga de aquíferos. A segunda fase do projeto investigou a eficiência de estruturas de recarga artificial nos seguintes locais de estudo: Coimbatore (Tamil Nadu, Índia), Kolwan Valley (Maharashtra, Nepal), Aravalli Hills (Gujarat, Índia), TBS Rajasthan (Índia) e Kathmandu Valley (Nepal).

A metodologia utilizada permitiu: a) melhorar o conhecimento dos impactos da recarga artificial em diferentes cenários físicos e socioeconômicos; b) elaborar um guia no âmbito da eficiência da recarga artificial para executores, tomadores de decisões e formadores de políticas, abordando os tipos de recarga artificial que deverão ser efetivos em termos de impacto no ciclo da água, particularmente no armazenamento subterrâneo, nos sistemas de gestão e acordos institucionais e a sua contribuição para a manutenção do estilo de vida das populações; c) disseminação de conhecimento.

A coordenação do projeto foi realizada por Ian Gale e as organizações participantes incluíram: Advanced Centre for Water Resources Development and Management (ACWADAM); Pune, Vikram Sarabhai Centre for Development Interaction (VIKSAT); Gujarat, Tamil Nadu Agricultural University (TNAU); Coimbatore Institute of Development Studies, India (IDSJaipur), Nepal Water Conservation Foundation (NWCF); Institute for Social and Environmental Transition, Nepal (ISET); UNESCO New Delhi Office and Paris Office; International Association of Hydrogeologists (IAH); Central Groundwater Board (CGWB), Government of India; 
Department of Drinking Water Supplies (DDWS).

Gale \& Dillon (2005), com o objetivo de reunir experiências de aplicação de recarga gerenciada de aquíferos em regiões semiáridas e fornecer orientações e exemplos de boas práticas em todo o mundo publicaram Strategies for Managed Aquifer Recharge (MAR) in semi-arid areas. Este documento foi elaborado pela Comissão IAH- International Association of Hydrogeologists, com o apoio do Programa Internacional de Hidrologia da UNESCO(IHP) e do Departamento Britânico para o Desenvolvimento Internacional (DFID).

Diaz et al. (2000) publicaram Recarga artificial de acuíferos. Síntesis metodológica. Estudios y actuaciones realizadas en la Provincia de Alicante. Septiembre 1999, que apresenta uma síntese dos métodos de recarga artificial de aquíferos e conceitos gerais. Abrange recarga artificial de aquíferos para abastecimento a núcleos urbanos. Estudos e Ações realizadas na Província de Alicante, sul da Espanha.

Entre os vários estudos sobre recarga artificial em aquíferos fraturados estão os trabalhos de Cadamuro et al. (2002), Murray \& Tredoux (2002), Sankaranna (2002), Harrington et al. (2002), Palanisami (2005), Ismail et al. (2005), Shawky (2005), Eaton \& Winship (2007), Heilweil et al. (2007), Dillon et al. (2010), entre outros (Almeida,2011).

Segundo Roseiro (2009), foi realizado um inventário sobre o número de casos de recarga artificial de aquíferos no mundo, num projeto piloto designado por "Artificial Recharge of Groundwater in the World“", coordenado pelo Acacia Institute e International Groundwater Resources Assessment Centre (IGRAC). Deste trabalho resultou um mapeamento preliminar do número de experiências de gestão de recarga artificial de aquíferos existentes no mundo através da ferramenta Global Groundwater Information System (2004), criada pelo IGRAC.

Nos últimos anos as práticas de recarga artificial de aquíferos tornaram-se extremamente comuns e eficazes no gerenciamento de recursos hídricos em diversas regiões do mundo. A ampliação de projetos e experimentos envolvendo recarga artificial é evidenciada com o crescente número de publicações sobre o tema, com destaque para os trabalhos publicados em sete edições do International Symposium on Artificial Recharge of Groundwater, realizados na Califórnia (1988), Flórida (1994), Amsterdã (1998), Adelaide (2002), Berlim (2005), Phoenix (2007) e Abu Dhabi (2010). O Brasil não acompanhou os avanços dos últimos anos e a prática de recarga artificial ainda é incipiente (Almeida, 2011).

\subsection{4 - APLICAÇÕES DA TÉCNICA DE RECARGA ARTIFICIAL DE AQUÍFEROS NO BRASIL}

A recarga artificial no Brasil é uma prática ainda pouco utilizada. Na última década algumas técnicas foram aplicadas em regiões especificas e com resultados vagamente conhecidos ou 
disseminados. Alguns avanços foram alcançados, com projetos acadêmicos experimentais e com a ampliação da agenda de discussões sobre gestão das águas subterrâneas (ALMEIDA, 2011). Em 2008, o Conselho Nacional dos Recursos Hídricos-CNRH publicou a Resolução 92/2008 condicionando a implantação de mecanismos de recarga artificial de aquíferos à autorização do órgão ambiental competente. Em 2013, publicou a Resolução no 153 que estabelece critérios e diretrizes para implantação de recarga artificial de aquíferos no território brasileiro.

Almeida (2011) relata que no final dos anos 90 iniciaram-se estudos visando à aplicação se técnicas de recarga artificial em aquíferos fraturados, em área de condomínio horizontal na Região Administrativa de Sobradinho, Distrito Federal (Cadamuro 2002, Cadamuro et al. 2002 e Cadamuro \& Campos 2005). Os autores avaliaram técnicas de recarga artificial em aquíferos profundos, com captação de água de chuva através de calha, em telhados experimentais. Foram testadas duas técnicas distintas de recarga artificial com injeção direta e indireta de água no aquífero fraturado.

A recarga indireta consiste na captação de água de chuva em telhados com posterior condução dessa água até caixas de infiltração no solo, com as seguintes dimensões: formato cilíndrico, com 1,0 a 2,5 m de profundidade e 1 metro de diâmetro, preenchidas com material composto por cascalho com previsão de maior infiltração vertical.

Os resultados alcançados sugerem que as técnicas de recarga aplicadas possibilitam aumento da disponibilidade hídrica com o incremento das áreas de recarga e minimização dos efeitos da impermeabilização do local, funcionando como importante ferramenta de gestão dos recursos hídricos (Almeida, 2011).

Técnicas de recarga foram testadas por Silva (2004), Silva et al. (2004) e Montenegro et al. (2005) na cidade de Recife, Chagas (2008) na cidade de Goiânia e no município de Araçuaí em Minas Gerais com a construção de 96 barragens para captação de água da chuva e contenção de enxurradas (Almeida, 2011)

Uma prática muito comum em diversas regiões do Brasil consiste na abertura de caixas de empréstimo para utilização do material terroso existente nas faixas de domínio de rodovias a fim de compor a estrutura do pavimento. Essas caixas também funcionam como bacias de infiltração embora o objetivo não seja este. Muitos sistemas de drenagem de rodovias também utilizam as chamadas bacias de retenção que são dimensionadas para funcionar como bacias de qualidade cuja função é reter os sedimentos finos e as de quantidade cuja função é controlar o escoamento, evitando dessa forma perturbações a jusante como inundações e processos erosivos. Essas estruturas funcionam também como bacias de infiltração. 


\section{3 - CONTAMINAÇÃO DAS ÁGUAS SUBTERRÂNEAS}

As diversas atividades exercidas pelo homem no solo podem introduzir no subsolo substâncias ou características físicas que ali não existiam antes, ou que existiam em quantidades diferentes. Como a recarga das águas no subsolo ocorre, na maioria dos casos, devido à infiltração da água de chuva em excesso no solo, essas atividades podem ameaçar a qualidade da água subterrânea (Ribeiro et al, 2007). A este processo chamamos de poluição. Assim como as atividades desenvolvidas pela humanidade são muito variáveis, também o são as formas e níveis de poluição.

No geral os depósitos de água subterrânea são bem mais resistentes aos processos poluidores dos que os de água superficial, pois a camada de solo sobrejacente atua como filtro físico e químico. A facilidade de um poluente atingir a água subterrânea dependerá dos seguintes fatores:

a) Tipo de aquífero,

b) Profundidade do nível estático: (espessura da zona de aeração)

c) Permeabilidade da zona de aeração e do aquífero;

d) Teor de matéria orgânica existente sobre o solo;

e) Tipo dos óxidos e minerais de argila existentes no solo.

A ocupação urbana traz riscos à contaminação das águas subterrâneas freáticas e profundas. Este risco é classificado em potencial ou efetivo e pode apresentar diferentes intensidades. A intensidade do risco é interpretada a partir do volume, persistência e toxidez das cargas poluentes que incidem na superfície do terreno ou a pequenas profundidades. Em uma análise das atividades do homem que podem gerar uma carga contaminante no subsolo é importante reconhecer quais fontes são de emissão pontual e quais são de emissão difusa. (Ribeiro et al, 2007).

Estudos sobre aspectos geotécnicos de solos que recebem efluentes de esgotamento sanitários in situ na Austrália em nove localidades, realizados por Whitehead \& Geary (2000), apresentaram elevados níveis de $\mathrm{NO}_{3}$. Os autores concluíram haver risco potencial de contaminação quando houver 15 ou mais esgotamento sanitários in situ $/ \mathrm{km}^{2}$ em uma região. 


\section{CAPÍTULO 3}

\section{RESULTADOS}

\section{1 - AVALIAÇÃo DA CONTAMINAÇÃO DOS AQUÍFEROS}

Para o Setor Habitacional Jardim Botânico todas as feições naturais resultam em área de elevado risco a contaminação. O relevo é relativamente plano com declividade inferior a $8 \%$ em toda a porção anterior à borda da chapada; os solos são rasos e apresentam elevada condutividade hidráulica, a zona não saturada é rasa a muito rasa, localmente ocorrem fraturas saturadas a 2,4 metros de profundidade e os solos são pobres em matéria orgânica e muito arenosos. Dessa forma os efluentes gerados no saneamento in situ não são atenuados na zona não saturada e a contaminação é rápida.

No caso do Condomínio San Diego o risco de contaminação é muito elevado por se tratar de solos arenosos sobre quartzitos e metarritmitos arenosos. No Condomínio Privê Lago Norte o risco é minimizado por se tratar de solos argilosos, entretanto, com o tempo e persistência da carga a contaminação deverá alcançar a zona saturada.

Dados de monitoramento de análises químicas realizados em poços tubulares operados pela CAESB mostram que a região do Setor Habitacional Jardim Botânico já apresenta problema de qualidade das águas subterrâneas devido ao sistema de saneamento que foi implantado desde o início da ocupação em 1990. A Tabela 3.1 apresenta resultados de análises químicas de águas de poços tubulares profundos operados pela CAESB, amostrados em julho e agosto de 2007.

A constatação da contaminação, em alguns casos registrada e em outros, considerada eminente, levou a própria CAESB a desativar inúmeros poços da região e a complementar o abastecimento a partir de manancial superficial (excedente da captação do córrego Cabeça de Veado, no interior da reserva ecológica do Jardim Botânico).

Os principais parâmetros que indicam que plumas de contaminação geradas pela infiltração dos esgotos já alcançaram o aquífero profundo são: sódio, cloreto, nitrato e coliformes. Dentre estes o nitrato é o mais representativo, pois nas rochas do Distrito Federal não existe nenhuma fase mineral que contenha nitrogênio, de forma que qualquer ocorrência de nitrato em águas subterrâneas só pode ser atribuída a contaminação a partir de infiltração de esgoto doméstico. Esta constatação também é apresentada em trabalhos acadêmicos relacionados às águas subterrâneas do DF, como por exemplo, Boaventura \& Freitas (2006).

No Distrito Federal a contaminação das águas freáticas e subterrâneas profundas já foi constatada em diferentes trabalhos (ex. Zoby 1999), sendo as fontes difusas na forma de fossas sépticas e negras as mais comuns. 


\begin{tabular}{|c|c|c|c|c|c|c|c|c|c|c|c|c|c|c|c|c|}
\hline VMP & $\begin{array}{l}6 \mathrm{a} \\
9,5\end{array}$ & - & 1000,0 & - & - & 500 & 0,30 & 0,2 & - & - & 200 & - & - & 250 & 10 & Aus. \\
\hline SB-01 & 5,3 & 30,6 & 20,8 & 2,7 & 27,06 & 5,50 & 0,107 & 0,09 & 0,20 & 1,20 & 3,9 & 0.6 & 3,3 & 1,20 & 1,904 & aus. \\
\hline SB-02 & 4,80 & 32,1 & 21,8 & 1,8 & 57,06 & 3,20 & 0,018 & 0,09 & 0,20 & 0,60 & 3,6 & 0.6 & 2,2 & 1,90 & 1,510 & aus. \\
\hline SB-04 & 5,80 & 9,5 & 6,5 & 4,3 & 13,63 & 4,40 & 0,053 & 0,10 & 0,30 & 0,90 & 0,2 & 0.2 & 5,2 & 0,60 & 0,066 & aus. \\
\hline SB-05 & 5,40 & 8,2 & 5,6 & 3,1 & 24,68 & 2,40 & 0,012 & 0,10 & 0,20 & 0,40 & 0,3 & 0.2 & 3,8 & 0,60 & 0,053 & aus. \\
\hline JB-01 & 4,30 & 84,3 & 57,3 & 0,0 & & 4,10 & 0,199 & 0,26 & 0,70 & 0,50 & 11,1 & 1.6 & 0,0 & 6,50 & 4,537 & aus. \\
\hline JB-02 & 4,30 & 97,8 & 66,6 & 0,8 & 80,19 & 5,90 & 0,091 & 0,24 & 1,20 & 0,70 & 11,8 & 1.5 & 1,0 & 6,90 & 5,534 & aus. \\
\hline JB-03 & 4,40 & 101,2 & 68,7 & 0,5 & 39,81 & 6,40 & 0,980 & 0,24 & 0,60 & 1,20 & 14,2 & 1.5 & 0,6 & 9,00 & 5,342 & 26,2 \\
\hline-05 & 4,40 & 68,3 & 46,4 & 2,5 & 199,05 & 2,50 & 0,026 & 0,26 & 0,40 & 0,40 & 9,2 & 1.3 & 3,1 & 4,90 & 3,651 & aus. \\
\hline SD-06 & 4,30 & 66,4 & 45,3 & 0,0 & & 2,60 & 0,049 & & 0,30 & 0,40 & 6,4 & 0.6 & 0,0 & 5,60 & 3,552 & aus. \\
\hline VM-3 & 4,50 & 39,1 & 26,5 & 0,6 & 37,95 & 5,60 & 0,006 & 0,28 & 1,10 & 0,70 & 4,7 & 1.2 & 1,2 & 3,40 & 3,590 & aus. \\
\hline VM-4 & 4,70 & 15,3 & 10,1 & 1,0 & 39,91 & 1,60 & $<0,005$ & 0,07 & 0,00 & 0,40 & 0,6 & 0.3 & 1,2 & 0,90 & 0,420 & aus. \\
\hline MS-1 & 4,90 & 9,6 & 6,6 & 2,2 & 55,39 & 1,20 & $<0,005$ & 0,04 & 0,00 & 0,30 & 0,6 & 0.2 & 2,7 & 0,70 & 0,328 & aus. \\
\hline MS-2 & 5,30 & 10,5 & 7,1 & 0,9 & 9,02 & 1,40 & 0,019 & 0,07 & 0,10 & 0,10 & 0,3 & 0.4 & 1,1 & 0,60 & 0,010 & aus. \\
\hline MS-3 & 5,10 & 11,0 & 7,5 & 2,1 & 33,36 & 1,70 & 0,014 & 0,08 & 0,00 & 0,40 & 0,3 & 0.4 & 2,6 & 0,50 & 0,250 & aus. \\
\hline MS-5 & 5,50 & 10,0 & 6,8 & 3,8 & 24,03 & 3,20 & 0,043 & 0,09 & 0,00 & 0,80 & 0,3 & 0.6 & 4,6 & 0,40 & 0,069 & aus. \\
\hline 1 & 5,20 & 5,4 & 3,7 & 2,7 & 34,07 & 1,60 & 0,033 & 0,08 & 0,00 & 0,40 & 0,2 & 0.1 & 3,3 & 0,40 & 0,086 & aus. \\
\hline
\end{tabular}

Tabela 3.1 - Resultados de análises químicas de águas de poços tubulares profundos operados pela

CAESB (amostragem em julho / agosto de 2007). Resultados destacados em vermelho representam valores acima do máximo permissível. Resultados destacados em amarelo representam valores de alerta.

$\mathrm{CE}$ - Condutividade elétrica em $\mu \mathrm{S} / \mathrm{cm}$, STD - sólidos totais dissolvidos, CT - coliformes totais em $\mathrm{NMP} / 100 \mathrm{ml}$ (número mais provável) e VMP - valor máximo permitido. Os demais representam valores de background dos aquíferos da região.

A ocupação urbana traz riscos à contaminação das águas subterrâneas freáticas e profundas. Este risco é classificado como potencial ou efetivo e pode apresentar diferentes intensidades. A intensidade do risco é interpretada a partir do volume, persistência e toxidez das cargas poluentes que incidem na superfície do terreno ou a pequenas profundidades.

O fracionamento do terreno natural e a efetiva ocupação urbana geram uma série de cargas potenciais para contaminação das águas subterrâneas com destaque para os efluentes domésticos em sistema de saneamento in situ que foi usado por mais de 25 anos e ainda é utilizado por vários condomínios da região.

No saneamento in situ os efluentes são infiltrados na própria área de geração. A infiltração pode ser de forma integral e direta, compondo fossas negras, ou apenas parcialmente, compondo as fossas sépticas. As fossas sépticas são compostas por um sistema de caixa impermeável que retém os sólidos (fossa) com uma caixa permeável que permite a infiltração da porção líquida do 
efluente (sumidouro ou vala de infiltração). No sistema séptico, a porção sólida denominada de lodo é periodicamente bombeada e transferida para as estações de tratamento, enquanto o líquido infiltra depois de sofrer oxidação e atenuação biológica na fossa.

Para a avaliação da contaminação efetiva das águas subterrâneas de determinada área é fundamental que os valores de base sejam conhecidos e que o monitoramento da qualidade seja processado, uma vez que a qualidade atual da água é decorrente de controles naturais (geogênicos e pedogênicos) e das modificações verificadas pela ação humana (controle antropogênico).

A mineralogia básica do Subsistema $\mathbf{R}_{\mathbf{3}} / \mathbf{Q}_{\mathbf{3}}$, substrato rochoso presente na região do Condomínio San Diego, constitui-se de quartzo e filossilicatos, dentre os quais se destacam a ilita e finas lâminas de muscovita (Mizuno, 2012). Geologicamente, as rochas componentes desse subsistema são inertes ou pouco reativas embora as águas que circulam pelos metapelitos possam apresentar íons de $\mathrm{Si}^{4+}, \mathrm{Fe}^{2+}, \mathrm{Mg}^{2+}, \mathrm{K}^{+}, \mathrm{Ca}^{2+}$ e $\mathrm{Na}^{+}$.

A composição química natural da água subterrânea é relacionada ao controle geogênico, isto é, os sais e íons presentes na água são decorrentes da interação da água de recarga com as rochas. Assim, qualquer componente presente na água é incorporado a partir de dissolução de minerais que compõem a rocha em profundidade.

Resultados de análises químicas de águas (Tabela 3.1) de poços tubulares profundos na mesma região operados pela CAESB (amostragem em julho / agosto de 2007) apresentam valores de alerta para nitrato, cloro e Fe total em poços de condomínios do Jardim Botânico. Resultados de pH e coliformes totais apresentam valores acima do máximo permissível.

A composição atual da água é relacionada ao controle antropogênico e é decorrente dos usos da superfície. Por exemplo, uma água natural na região do Distrito Federal contém valores baixíssimos de chumbo, de forma que se forem encontradas elevadas concentrações deste metal a única explicação seria a contaminação local a partir da infiltração indesejada de substâncias ricas em chumbo. Os valores baixos de metais nas águas subterrâneas são decorrentes da composição dos minerais encontrados nas rochas que em última análise formam os aquíferos.

A efetiva contaminação dos recursos hídricos subterrâneos é produto da interação da carga contaminante com as características naturais do terreno, principalmente quanto à condutividade hidráulica (quanto maior a condutividade, maior o risco), espessura da zona não saturada (quanto menor a espessura, maior o risco), conteúdo de argila e carbono orgânico (quanto menor o conteúdo de argila, maior o risco), declividade do terreno (quanto menor a inclinação maior o risco) e recarga (quanto maior a recarga, maior o risco).

O resultado do Enquadramento dos Aquíferos do Distrito Federal (Mapa Diagnóstico - Figura 3.1) mostra que 18,65\% das águas da região dos condomínios do Jardim Botânico são classificadas nas classes 4 e 5, as quais requerem medidas de recuperação e mitigação efetivas. Pode-se constatar 
que o principal indicador de fonte poluidora é o nitrato, já que seus valores anômalos são decorrentes de histórico de ocupação e expansão demográfica sem saneamento adequado e ocorrências de infiltração direta de esgotamento sanitário nos aquíferos (Castanheira, 2016). Como no Distrito Federal não existem águas naturalmente enquadradas na Classe 5 o trabalho de Castanheira (2016) considerou a Classe 5 como água com elevado grau de contaminação antrópica.

As águas coletadas das nascentes, na unidade hidrográfica do Ribeirão Taboca, estão enquadradas na Classe 5 (Figura 3.1) de acordo com o Mapa Diagnóstico de Enquadramento de Aquíferos do Distrito Federal (Castanheira, 2016).

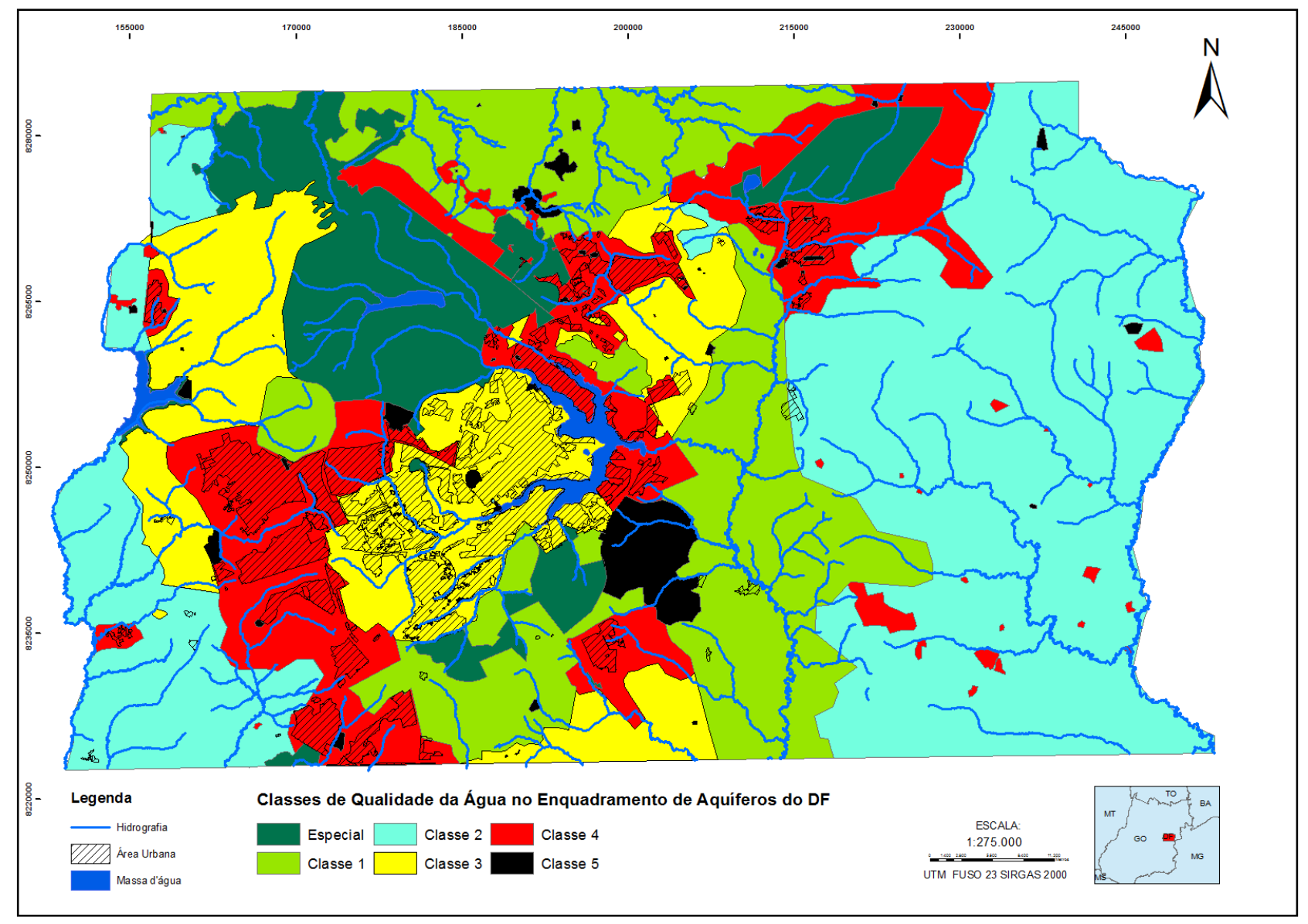

Figura 3.1 - Mapa do Enquadramento dos Corpos Hídricos Subterrâneos do Distrito Federal - Diagnóstico (Castanheira, 2016).

Os resultados apresentados na Tabela 3.2 mostram que as águas captadas pela Hydrate Água Mineral Natural, cuja fonte se localiza na mesma região do Jardim Botânico em estudo (Figura 3.3) já apresentam efeitos do saneamento in situ realizado nos últimos anos nos condomínios da região. A captação está a 600 metros da entrada principal do Condomínio San Diego.

Os principais parâmetros que indicam o processo inicial de contaminação são: a elevação consistente da condutividade elétrica da água que praticamente dobra em pouco menos de 3 anos (entre 2005 e 2008) e continua a subir em 2015 (Figura 3.2), bem como o sódio, cloreto, substâncias adicionadas ao aquífero a partir de urina humana (infiltrada a partir dos sistemas de fossas, fossas e sumidouros ou fossas e valas de infiltração). O nitrato não aparece no rótulo de 
2015, mas apresentou tendência de elevação nos últimos anos.

\begin{tabular}{|c|c|c|c|c|c|}
\hline Parâmetro & $\mathbf{1 9 9 9}$ & $\mathbf{2 0 0 5}$ & $\mathbf{2 0 0 8}$ & $\mathbf{2 0 1 1}$ & $\mathbf{2 0 1 5}$ \\
\hline $\mathrm{pH}$ & 5,00 & 4,83 & 4,55 & 4,56 & 4,48 \\
\hline $\mathrm{CE}(\mu \mathrm{s} / \mathrm{cm})$ & - & 15,5 & 29,8 & 26,1 & 37,6 \\
\hline Cálcio & 0,16 & 0,15 & 0,09 & 0,207 & - \\
\hline Magnésio & 0,12 & 0,08 & 0,10 & 0,13 & 0,17 \\
\hline Sódio & 0,73 & 1,11 & 4,07 & 3,04 & 5,79 \\
\hline Cloreto & 0,26 & 0,60 & 1,57 & 2,18 & 3,89 \\
\hline Nitrato & 0,46 & 2,90 & 6,30 & 6,11 & - \\
\hline Bicarbonato & 1,97 & 0,24 & 3,67 & 0,35 & 1,11 \\
\hline
\end{tabular}

Tabela 3.2 - Resultados de análises químicas constantes de rótulos de águas envasadas pela empresa Hydrate Água Mineral Natural.

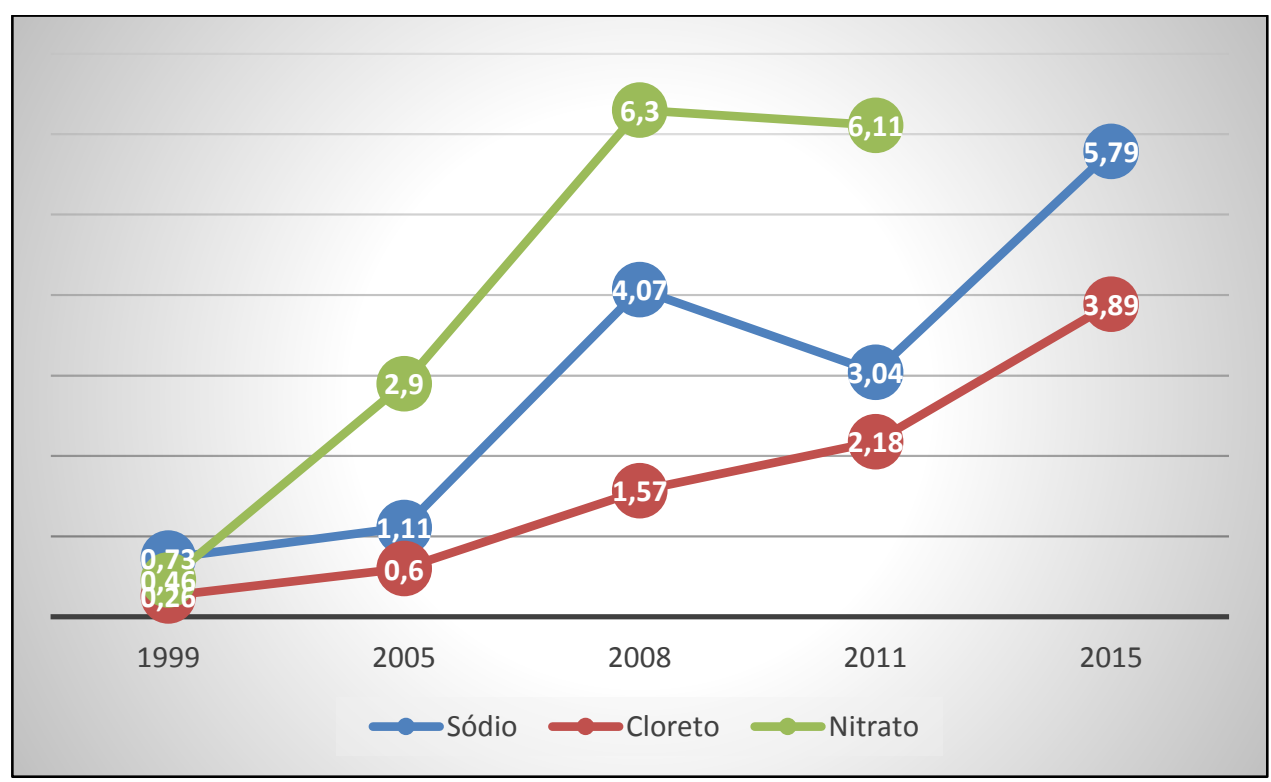

Figura 3. 2 Gráficos de tendência de elevação dos teores de $\mathrm{NO}_{3}, \mathrm{Cl}^{-}$e $\mathrm{Na}^{+}$. Amostras coletadas na saída do poço e análises realizadas pelo LAMIN - Laboratório de Análises Minerais do Serviço Geológico do Brasil.

Os resultados obtidos para o íon nitrato (Tabela 3.3) mostram que a contaminação alcançou as nascentes da borda da chapada, exutórios das águas infiltradas na região dos condomínios do Jardim Botânico.

Foram coletadas amostras de água em seis pontos dos diferentes canais formados pelas nascentes da borda da chapada (Figura 3.3) que se juntam para formar o Ribeirão Taboca. Essa amostragem teve como objetivo verificar a extensão da pluma de contaminação, já que, como dito anteriormente essas nascentes são pontos de descargas dos aquíferos à montante.

Note que a água coletada no ponto 3 apresentou o maior valor dentre as coletadas nas diversas nascentes possivelmente devido ao fato de receber influência de uma série de outras nascentes difusas que drenam as águas infiltradas na região dos diversos condomínios da Região Administrativa do Jardim Botânico (Tabela 3.3). A água da nascente, pontos de coleta 1 e 4 apresentou valores mais baixos para o íon nitrato, entretanto, esses valores ainda estão acima do 
background para as águas do Distrito Federal.

\begin{tabular}{|c|c|c|c|c|c|c|c|c|c|}
\hline \multirow{2}{*}{ PONTOS } & \multirow{2}{*}{ DATA } & \multirow{2}{*}{ HORA } & \multicolumn{6}{|c|}{ PARÂMETROS -NASCENTES DO RIBEIRAO TABOCA } \\
\cline { 4 - 10 } & & & $\mathrm{T}\left({ }^{\circ} \mathrm{c}\right)$ & $\mathrm{OD}(\%)$ & $\mathrm{OD}(\mathrm{mg} / \mathrm{l})$ & $\begin{array}{c}\mathrm{TDS} \\
(\mu \mathrm{S} / \mathrm{cm})\end{array}$ & $\mathrm{C}(\mu \mathrm{S} / \mathrm{cm})$ & $\begin{array}{c}\mathrm{N} \mathrm{NH}^{+}{ }_{4} \\
(\mathrm{mg} / \mathrm{l})\end{array}$ & $\begin{array}{c}\mathrm{N} \mathrm{NO}_{4}{ }^{+}{ }^{3-} \\
(\mathrm{mg})\end{array}$ \\
\hline 1 & $12 / 05 / 2016$ & $10: 32$ & 18,4 & 54,6 & 5,13 & 6,8 & 6,0 & 0,06 & 0,20 \\
\hline 2 & $12 / 05 / 2016$ & $10: 47$ & 19,0 & 56,5 & 5,21 & 7,7 & 7,4 & 0,06 & 0,40 \\
\hline 3 & $04 / 09 / 2016$ & $10: 23$ & 23,1 & 44,8 & 3,83 & 145,2 & 141,00 & 0,10 & 1,10 \\
\hline 4 & $04 / 09 / 2016$ & $09: 56$ & 23,4 & 36,3 & 3,09 & 7,8 & 7,5 & 0,09 & 0,12 \\
\hline 5 & $04 / 09 / 2016$ & $11: 15$ & 22,7 & 45,5 & 3,92 & 95,4 & 91,2 & 0,05 & 0,27 \\
\hline 6 & $04 / 09 / 2016$ & $11: 17$ & 23,4 & 42,4 & 3.61 & 95,3 & 92,5 & 0,02 & 0,68 \\
\hline
\end{tabular}

Tabela 3.3 - Resultados de análise química in situ de águas das nascentes do Ribeirão Taboca.

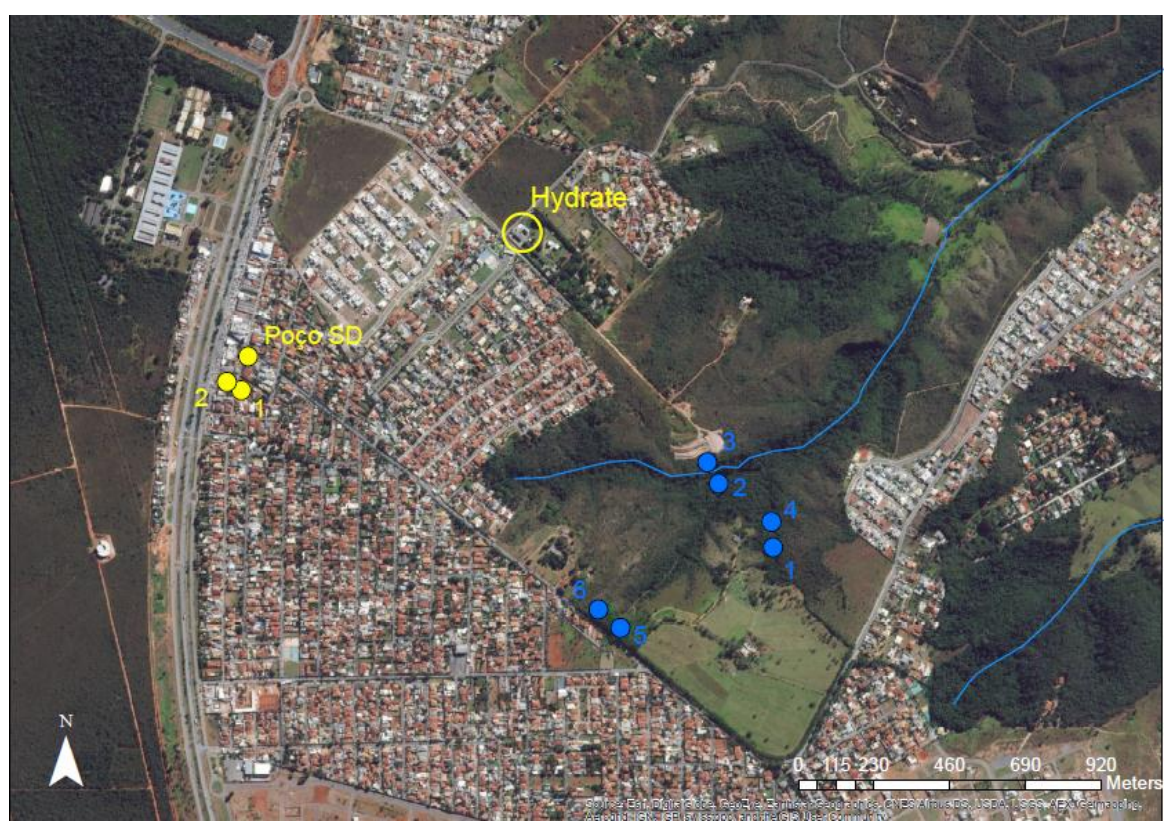

Figura 33 -Localização dos poços amostrados no Condomínio San Diego e da Hydrate Água Mineral Natural (em amarelo) e das nascentes amostradas que fluem para o Ribeirão Taboca (em azul).

A Figura 3.3 mostra a localização das nascentes visitadas que são exutórios dos aquíferos situados a montante, dos poços em que também foi determinada a contaminação e da captação da Água Mineral Hydrate. As Figuras 3.4 e 3.5 mostram aspectos de campo das nascentes visitadas. 

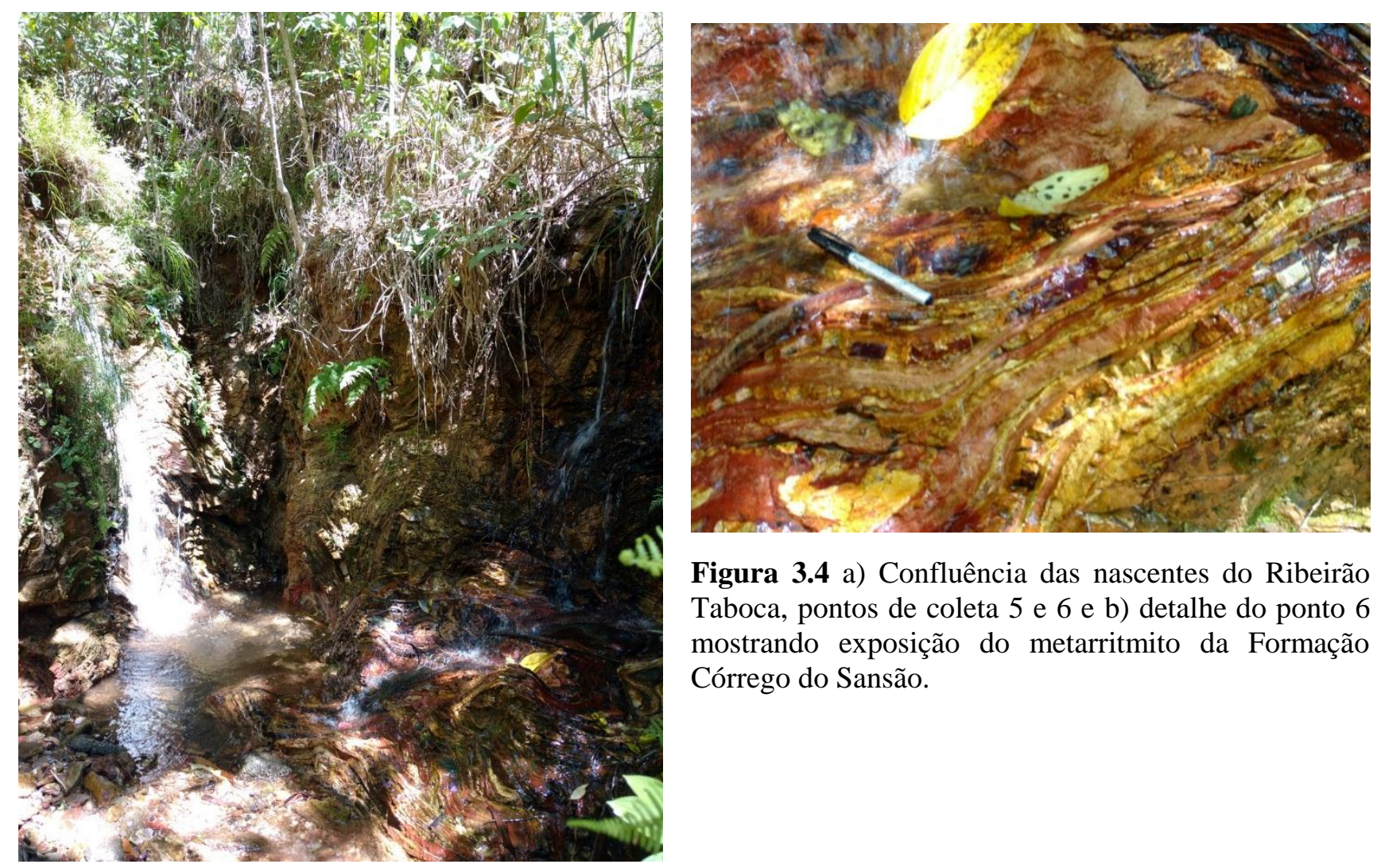

Figura 3.4 a) Confluência das nascentes do Ribeirão Taboca, pontos de coleta 5 e 6 e b) detalhe do ponto 6 mostrando exposição do metarritmito da Formação Córrego do Sansão.
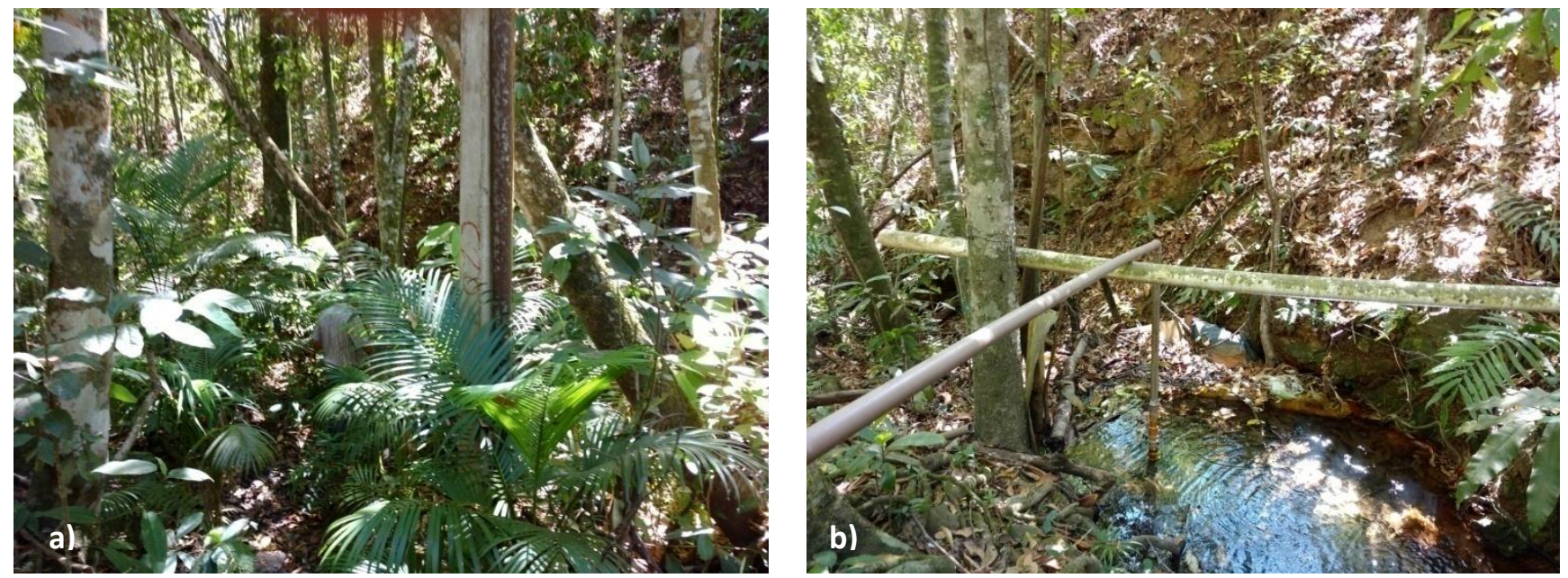

Figura 3.5 a) Vista geral do local de coleta- pontos 1 e 4 e b) Local da coleta. A água desta nascente é captada por bomba e utilizada para consumo pelos moradores da Chácara. Apresentou os menores valores do parâmetro Nitrato. O local apresenta ambiente mais preservado.

As análises in situ das águas de dois poços tubulares profundos internos ao Condomínio San Diego (Tabela 3.4) apresentaram valores que demonstram contaminação do aquífero. Os dados mostram níveis para o íon nitrato acima do limite de potabilidade para o poço 2 . A água retirada desse poço apresentou odor desagradável o que sugere que esteja estagnada, devido ao fato de o poço estar desativado. 


\begin{tabular}{|c|c|c|c|c|c|c|c|c|c|c|}
\hline \multirow{2}{*}{ POÇO } & \multirow{2}{*}{ DATA } & \multirow{2}{*}{ HORA } & \multicolumn{7}{|c|}{ PARÂMETROS-POÇOS 1 e 2 } \\
\cline { 5 - 11 } & & & $\mathrm{T}\left({ }^{\circ} \mathrm{c}\right)$ & $\mathrm{OD}(\%)$ & $\mathrm{OD}(\mathrm{mg} / \mathrm{l})$ & $\begin{array}{c}\mathrm{TDS} \\
(\mu \mathrm{S} / \mathrm{cm})\end{array}$ & $\mathrm{C}(\mu \mathrm{S})$ & $\begin{array}{c}\mathrm{N} \mathrm{NH}^{+} 4- \\
(\mathrm{mg} / \mathrm{l})\end{array}$ & $\begin{array}{c}\mathrm{N} \mathrm{NO}_{4}{ }^{+} 3- \\
(\mathrm{mg} / \mathrm{l})\end{array}$ & $\mathrm{NE}$ \\
\hline 1 & $27 / 09 / 2016$ & $13: 46$ & 26,6 & 2,27 & 28,3 & 336,6 & 346,8 & 4,69 & 6,12 & $8 \mathrm{~m}$ \\
\hline 2 & $27 / 09 / 2016$ & $13: 56$ & 26,6 & 1,78 & 22,1 & 467,3 & 478,8 & 5,31 & 10,34 & $13 \mathrm{~m}$ \\
\hline 2 & $27 / 09 / 2016$ & $15: 02$ & 27,3 & 2,63 & 33,0 & 474,0 & 492,4 & 4,3 & 12,91 & $13 \mathrm{~m}$ \\
\hline
\end{tabular}

Tabela 3.4 - Resultados de análise in situ de águas dos poços 1 e 2 (internos) do Condomínio San Diego.

Os resultados para o nitrato apresentados na Tabela 3.5 para as águas analisadas do poço San Diego mostram uma contaminação persistente com valores de nitrato variando de 0,60 a 1,99 $\mathrm{mg} / \mathrm{L}$.

\begin{tabular}{|c|c|c|c|c|c|c|c|}
\hline \multirow{2}{*}{ DATA } & \multirow{2}{*}{ HORA } & \multicolumn{7}{|c|}{ PARÂMETROS-POÇO SD 1 } \\
\cline { 3 - 8 } & & $\mathrm{T}\left({ }^{\circ} \mathrm{c}\right)$ & $\mathrm{OD}(\%)$ & $\mathrm{OD}(\mathrm{mg} / \mathrm{l})$ & $\begin{array}{c}\mathrm{TDS} \\
(\mu \mathrm{S} / \mathrm{cm})\end{array}$ & $\begin{array}{c}\mathrm{N} \mathrm{NH}^{+}{ }_{4-} \\
(\mathrm{mg} / \mathrm{l})\end{array}$ & $\begin{array}{c}\mathrm{N} \mathrm{NO}{ }^{+} 3- \\
(\mathrm{mg} / \mathrm{l})\end{array}$ \\
\hline $12 / 05 / 2016$ & $11: 30$ & 25,3 & 22,1 & 1,82 & 100,9 & 0,08 & 0,73 \\
\hline $15 / 05 / 2016$ & $11: 00$ & 24,6 & 27,9 & 2,32 & 112,5 & 0,13 & 1,21 \\
\hline $15 / 05 / 2016$ & $11: 30$ & 24,7 & 28,3 & 2,1 & 110,7 & 0,08 & 1,16 \\
\hline $15 / 05 / 2016$ & $12: 00$ & 25,6 & 37,0 & 3,02 & 109,6 & 0,03 & 0,80 \\
\hline $15 / 05 / 2016$ & $12: 30$ & 25,7 & 36,0 & 2,94 & 102,5 & 0,03 & 0,86 \\
\hline $15 / 05 / 2016$ & $13: 00$ & 25,8 & 30,6 & 2,49 & 109,0 & 0,03 & 0,99 \\
\hline $09 / 06 / 2016$ & $11: 30$ & 20,6 & 64,5 & 5,8 & 91,2 & 0,14 & 0,85 \\
\hline $12 / 06 / 2016$ & $11: 00$ & 23,9 & 37,0 & 3,14 & 97,6 & 0,02 & 1,16 \\
\hline $12 / 06 / 2016$ & $12: 00$ & 24,8 & 34,7 & 2,88 & 97,2 & 0,03 & 0,96 \\
\hline $16 / 09 / 2016$ & $10: 00$ & 25,5 & 42,9 & 3,34 & 95,7 & 0,07 & 1,60 \\
\hline $18 / 09 / 2016$ & $10: 00$ & 24,4 & 33,4 & 2,79 & 94,1 & 0,05 & 0,87 \\
\hline $18 / 09 / 2016$ & $11: 00$ & 24,4 & 34,2 & 2,86 & 94,4 & 0,03 & 1,86 \\
\hline $26 / 09 / 2016$ & $10: 00$ & 24,3 & 36,0 & 3,02 & 96,9 & 0,08 & 0,73 \\
\hline $26 / 09 / 2016$ & $11: 00$ & 24,5 & 31,4 & 2,62 & 93,9 & 0,07 & 0,60 \\
\hline $26 / 09 / 2016$ & $12: 00$ & 24,9 & 32,4 & 2,67 & 94,4 & 0,07 & 0,62 \\
\hline $27 / 09 / 2016$ & $09: 15$ & 24,4 & 33,6 & 2,8 & 95,2 & 0,04 & 1,11 \\
\hline $27 / 09 / 2016$ & $10: 06$ & 24,7 & 36,2 & 3,01 & 95,3 & 0,06 & 0,73 \\
\hline $27 / 09 / 2016$ & $11: 38$ & 25,7 & 30,2 & 2,46 & 95,7 & 0,05 & 0,83 \\
\hline $27 / 09 / 2016$ & $12: 06$ & 25,3 & 34,9 & 2,86 & 96,0 & 0,04 & 1,08 \\
\hline $27 / 09 / 2016$ & $13: 08$ & 24,8 & 34,6 & 2,88 & 95,0 & 0,07 & 0,66 \\
\hline $27 / 09 / 2016$ & $14: 15$ & 24,5 & 34,9 & 2,91 & 95,1 & 0,09 & 0,63 \\
\hline $27 / 09 / 2016$ & $15: 22$ & 24,4 & 34,5 & 2,88 & 102,5 & 0,10 & 0,93 \\
\hline $27 / 09 / 2016$ & $16: 15$ & 24,5 & 35,9 & 3,00 & 95,4 & 0,04 & 1,29 \\
\hline $10 / 10 / 2016$ & $09: 40$ & 24,3 & 35,1 & 2,94 & 102,4 & 0,08 & 0,92 \\
\hline $10 / 10 / 2016$ & $10: 04$ & 24,7 & 34,7 & 2,88 & 96,2 & 0,05 & 0,95 \\
\hline $11 / 10 / 2016$ & $08: 29$ & 24,0 & 37,4 & 3,15 & 106,6 & 0,05 & 1,94 \\
\hline $12 / 10 / 2016$ & $11: 12$ & 24,5 & 36,5 & 3,05 & 101,5 & 0,04 & 1,99 \\
\hline $13 / 10 / 2016$ & $08: 47$ & 23,9 & 37,5 & 3,16 & 99,3 & 0,07 & 1,42 \\
\hline
\end{tabular}




\begin{tabular}{|l|l|l|l|l|l|l|l|}
$14 / 10 / 2016$ & $16: 06$ & 25,1 & 31,7 & 2,61 & 98,1 & 0,07 & 0,70 \\
\hline $15 / 10 / 2016$ & $12: 12$ & 25,0 & 36,2 & 2,99 & 99,7 & 0,06 & 1,01 \\
\hline $16 / 10 / 2016$ & $08: 49$ & 25,2 & 32,7 & 2,69 & 96,8 & 0,07 & 1,21 \\
\hline $17 / 10 / 2016$ & $08: 13$ & 24,5 & 34,2 & 2,85 & 95,2 & 0,07 & 1,06 \\
\hline $18 / 10 / 2016$ & $07: 50$ & 24,3 & 36,7 & 3,07 & 95,5 & 0,07 & 0,64 \\
\hline $19 / 10 / 2016$ & $07: 57$ & 24,9 & 33,7 & 2,79 & 94,5 & 0,07 & 0,72 \\
\hline $31 / 10 / 2016$ & $14: 53$ & 26,1 & 39,6 & 3,21 & 99,0 & 0,00 & 1,73 \\
\hline
\end{tabular}

Tabela 3.5 - Resultados de determinações químicas de águas do poço tubular profundo do Projeto Piloto situado no Condomínio San Diego.

A condutividade elétrica das águas é outro fator que mostra de forma indiscutível a extensão da contaminação, uma vez que nas águas naturais não contaminadas deste mesmo Subsistema Aquífero os valores são inferiores a $30 \mu \mathrm{S}$. Determinações in situ realizadas nas águas transportadas pelos caminhões pipa utilizados nos ensaios hidráulicos são apresentadas na Tabela 3.6.

\begin{tabular}{|c|c|c|c|c|c|c|c|c|c|}
\hline \multirow{2}{*}{ DATA } & \multirow{2}{*}{ VOLUME } & \multirow{2}{*}{ HORA } & \multicolumn{7}{|c|}{ PARÂMETROS ÁGUAS INJETADAS } \\
\cline { 5 - 10 } & & $\mathrm{T}\left({ }^{\circ} \mathrm{c}\right)$ & $\mathrm{OD}(\%)$ & $\mathrm{OD}(\mathrm{mg} / \mathrm{l})$ & $\begin{array}{c}\mathrm{TDS} \\
(\mu \mathrm{S} / \mathrm{cm})\end{array}$ & $\begin{array}{c}\mathrm{CE} \\
(\mu \mathrm{S} / \mathrm{cm})\end{array}$ & $\begin{array}{c}\mathrm{N} \mathrm{NH}^{+}{ }_{4-} \\
(\mathrm{mg} / \mathrm{l})\end{array}$ & $\begin{array}{c}\mathrm{N} \mathrm{NO}_{4}{ }^{+} 3- \\
(\mathrm{mg} / \mathrm{l})\end{array}$ \\
\hline $12 / 05 / 2016$ & $4.500 \mathrm{~L}$ & $09: 00$ & 28,3 & 53,5 & 4,17 & 5,2 & 5,5 & 0,02 & 0,44 \\
\hline $09 / 06 / 2016$ & $5.000 \mathrm{~L}$ & $10: 05$ & 20,5 & 77,1 & 6,95 & 24,9 & 22,7 & 0,05 & 0,75 \\
\hline $16 / 09 / 2016$ & $7.000 \mathrm{~L}$ & $08: 30$ & 25,4 & 56,3 & 4,61 & 3,8 & 3,8 & 0,05 & 0,04 \\
\hline $26 / 09 / 2016$ & $7.000 \mathrm{~L}$ & $08: 40$ & 23,4 & 51,8 & 4,41 & 4,6 & 4,5 & 0,01 & 0,05 \\
\hline $10 / 10 / 2016$ & $15.000 \mathrm{~L}$ & $09: 30$ & 23,4 & 50,8 & 4,33 & 7,00 & 6,7 & 0,05 & 0,05 \\
\hline
\end{tabular}

Tabela 3.6 - Resultados de águas dos caminhões pipa utilizados no Projeto Piloto I.

Os dados do poço da Vila Telebrasília já indicam alguma influência de contaminação, o que mostra que estas águas não são adequadas para o estudo em desenvolvimento.

\section{2 - CAPACIDADE MÁXIMA DE INFILTRAÇÃO}

O objetivo dos ensaios hidráulicos realizados nos Projetos de Recarga Piloto I e II foi no sentido de se obter a capacidade máxima de infiltração na região do Condomínio San Diego e Condomínio Privê I.

\subsection{1 - PROJETO PILOTO I- CONDOMÍNIO SAN DIEGO}

Os ensaios realizados na região no Sistema de Recarga do Projeto Piloto I, Condomínio San Diego, aconteceram nos dia 16, 26/09 e 10/10/2016. No ensaio realizado no dia 16 não se utilizou nenhum critério de escolha de vazão, até mesmo porque o objetivo era obter uma vazão adequada para que fosse possível infiltrar todo o volume do caminhão pipa em uma fase de teste. Calculouse a vazão instantânea na saída da mangueira do caminhão pipa quando se obteve $5904 \mathrm{~L} / \mathrm{h}$. Para essa vazão houve extravasamento de água na quadra de esporte do condomínio em uma hora de ensaio. 
No ensaio do dia 26/09/2016 optou-se por observar qual vazão seria a adequada para que não houvesse extravasamento. O tempo necessário para injetar o mesmo volume injetado no ensaio anterior, ou seja, 7.000 L, sem que houvesse derramamento de água foi da ordem de duas horas e meia. Obteve-se então uma vazão média de $2.800 \mathrm{~L} / \mathrm{h}$.

Para o ensaio seguinte, no dia 10/10/2016, aumentou-se o volume de injeção para 15.000 L e obteve-se uma vazão média de $3.464 \mathrm{~L} / \mathrm{h}$. Nesse ensaio não houve derramamento de água, ou seja, toda a água injetada na caixa de infiltração teve como destino os sistemas aquíferos subjacentes. A Tabela 3.7 apresenta os dados dos volumes injetados e as respectivas vazões.

\begin{tabular}{|c|c|c|}
\hline DATA & $\begin{array}{c}\text { VOLUME } \\
\text { INJETADO }\end{array}$ & $\begin{array}{c}\text { VAZÃÕ } \\
\text { MÉDIA(L/h) }\end{array}$ \\
\hline $\mathbf{1 2 / 0 5 / 2 0 1 6}$ & $4.500 \mathrm{~L}$ & 3.000 \\
\hline $\mathbf{0 9 / 0 6 / 2 0 1 6}$ & $5.000 \mathrm{~L}$ & 2.500 \\
\hline $\mathbf{1 6 / 0 9 / 2 0 1 6}$ & $7.000 \mathrm{~L}$ & 5.904 \\
\hline $\mathbf{2 6 / 0 9 / 2 0 1 6}$ & $7.000 \mathrm{~L}$ & 2800 \\
\hline $\mathbf{1 0 / 1 0 / 2 0 1 6}$ & $15.000 \mathrm{~L}$ & 3.464 \\
\hline
\end{tabular}

Tabela 3.7 - Dados dos volumes injetados e vazão média

\subsection{2 - PROJETO PILOTO II- CONDOMÍNIO PRIVE}

O ensaio no Condomínio Privê foi realizado utilizando uma vazão média de $1000 \mathrm{~L} / \mathrm{h}$. Após cerca de 1 hora observou-se um acréscimo no valor da condutividade elétrica que permaneceu se elevando até o final do ensaio, ou seja, por mais 6 horas e 45min (Tabela 3.9).

\section{3 - TEMPO DE CHEGADA DAS ÁGUAS DE INFILTRAÇÃO}

No Distrito Federal as condições de circulação associada ao padrão de relevo, estruturação tectônica e variações das coberturas dos solos permitem o desenvolvimento de sistemas de fluxo hidrogeológico locais e intermediários conforme Campos et al (2007).

Ainda de acordo com Campos et al (2007) os resultados de estudos permitem afirmar que as águas subterrâneas da região do Distrito Federal são jovens e há significativo lapso de tempo para a infiltração das águas freáticas até ocupar os espaços vazios nos meios fraturados em profundidade.

\subsection{1 - PROJETO DE RECARGA PILOTO I- CONDOMÍNIO SAN DIEGO}

Os primeiros ensaios realizados no Projeto de Recarga Piloto I objetivaram a diluição dos contaminantes a partir da injeção de água de recarga da chuva captadas do telhado e direcionadas para a caixa de infiltração. A retirada de água do poço próximo da caixa de infiltração para análise de parâmetros físico-químicos visava à observação de uma possível diluição do contaminante nitrato.

Como não foi possível relacionar a injeção das águas dos primeiros ensaios às variações 
ocorridas no nível de nitrato nas águas retiradas do poço decidiu-se por verificar qual a capacidade máxima de infiltração do Sistema $\mathbf{P}_{\mathbf{1}}$ e Subsistema $\mathbf{R}_{\mathbf{3}} / \mathbf{Q}_{\mathbf{3}}$, presentes no local.

Os resultados obtidos para as medições do nível freático do poço SD 01 mostrados na tabela 3.8 revelam que nos dez dias após a injeção de 15.000 L o nível freático não apresentou variação significante. Embora os valores da condutividade elétrica não tenham se alterado nesse período, o que indicaria chegada das águas injetadas na caixa de infiltração ao poço, acredita-se que uma pequena quantidade dessas águas injetadas possa ter alcançado o referido poço.

\begin{tabular}{|c|c|c|c|c|c|}
\hline \multicolumn{7}{|c|}{ POCO SAN DIEGO } \\
\hline DATA & $\begin{array}{c}\text { VAZÃO } \\
\text { MÉDIA } \\
\text { (L/h) }\end{array}$ & NA & DATA & $\begin{array}{c}\text { VAZÃO } \\
\text { MÉDIA } \\
\text { (L/h) }\end{array}$ & NA \\
\hline $\mathbf{2 5 / 0 1 / 2 0 1 6}$ & & 15,32 & $\mathbf{1 1 / 1 0 / 2 0 1 6}$ & & 25,03 \\
\hline $\mathbf{2 2 / 0 2 / 2 0 1 6}$ & & 15,23 & $\mathbf{1 2 / 1 0 / 2 0 1 6}$ & & 25,02 \\
\hline $\mathbf{2 1 / 0 3 / 2 0 1 6}$ & & 14,87 & $\mathbf{1 3 / 1 0 / 2 0 1 6}$ & & 25,05 \\
\hline $\mathbf{2 0 / 0 4 / 2 0 1 6}$ & & 16,31 & $\mathbf{1 4 / 1 0 / 2 0 1 6}$ & & 25,03 \\
\hline $\mathbf{1 2 / 0 5 / 2 0 1 6}$ & 3.000 & - & $\mathbf{1 5 / 1 0 / 2 0 1 6}$ & & 25,06 \\
\hline $\mathbf{0 9 / 0 6 / 2 0 1 6}$ & 2.500 & - & $\mathbf{1 6 / 1 0 / 2 0 1 6}$ & & 25,06 \\
\hline $\mathbf{2 3 / 0 8 / 2 0 1 6}$ & & 23,72 & $\mathbf{1 7 / 1 0 / 2 0 1 6}$ & & 25,11 \\
\hline $\mathbf{0 4 / 0 9 / 2 0 1 6}$ & & 24,29 & $\mathbf{1 8 / 1 0 / 2 0 1 6}$ & & 25,03 \\
\hline $\mathbf{1 6 / 0 9 / 2 0 1 6}$ & 5.904 & 24,58 & $\mathbf{1 9 / 1 0 / 2 0 1 6}$ & & 25,15 \\
\hline $\mathbf{1 8 / 0 9 / 2 0 1 6}$ & & 24,59 & $\mathbf{2 1 / 1 0 / 2 0 1 6}$ & & 25,22 \\
\hline $\mathbf{2 6 / 0 9 / 2 0 1 6}$ & 2.800 & 24,75 & $25 / 10 / 2016$ & & 25,33 \\
\hline $\mathbf{2 7 / 0 9 / 2 0 1 6}$ & & 24,85 & $27 / 10 / 2016$ & & 25,39 \\
\hline $\mathbf{1 0 / 1 0 / 2 0 1 6}$ & 3.464 & 25,01 & $31 / 10 / 2016$ & & 25,43 \\
\hline
\end{tabular}

Tabela 3.8 - Resultado das medições do nível de água do poço do Projeto Piloto I- Em azul os dias em que houve injeção de água na caixa de infiltração. 16/09/2016 - 7.000 L, 26/09/2016 - 7.000 L, 10/10/2016 15.000 L além dos dias 12/05/2016 e 09/06/2016 com 4.500 L e 5.000L, respectivamente.

Os dados apresentados no gráfico (Figura 3.6) mostram uma variação de quase $10 \mathrm{~m}$ de rebaixamento do período de janeiro até outubro/2016 com queda acentuada no período de estiagem, ou seja, de abril a agosto.

Medições do nível freático do poço San Diego observados ao longo de 2016 demonstram um comportamento semelhante se comparado com os dados da série histórica disponibilizada pela CAESB, ou seja, elevação no período das chuvas e rebaixamento no período de estiagem (Figura 3.7). As variações entre os diferentes anos de observação a partir de 2010 são interpretação como função da sazonalidade climática, sendo que anos que apresentam níveis mais elevados respondem às chuvas mais intensas no ano anterior. Os anos nos quais os níveis flutuam em patamares mais baixos respondem a chuvas menos intensas ou a acumulados menores no ano anterior. As flutuações dos anos de 2007 e 2008 são devidas ao bombeamento, pois este poço ainda estava integrado ao sistema de abastecimento do condomínio San Diego. 


\section{Variação mensal NA- SD 01}

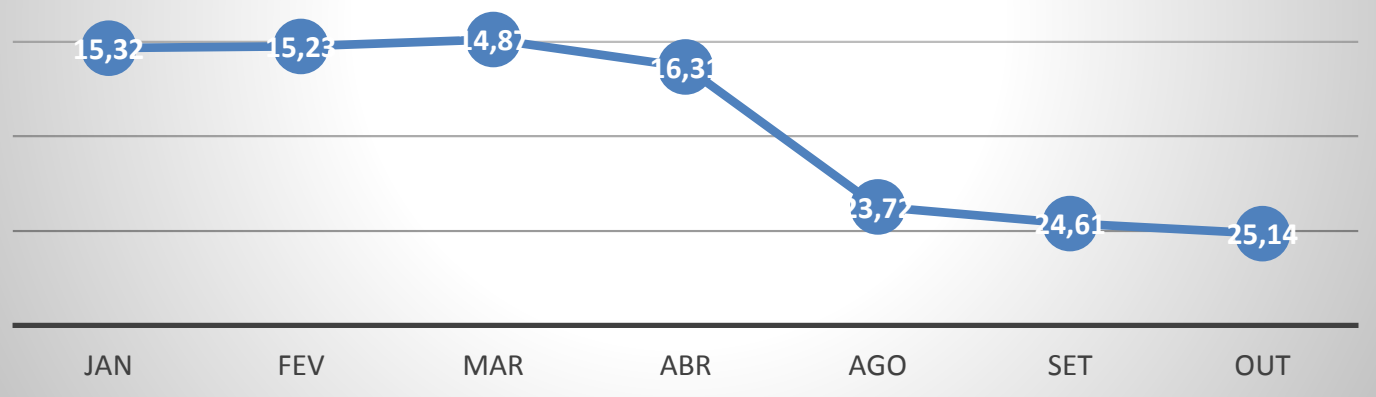

Figura 3.6 - Variação do NA do poço do Condomínio San Diego de Jan a Out/2016.

\subsection{2 - PROJETO DE RECARGA PILOTO II - CONDOMÍNIO PRIVÊ}

A elevação da condutividade elétrica mostrada na Tabela 3.9 está relacionada com a chegada das águas injetadas adicionadas de $\mathrm{NaCl}$ na caixa de infiltração. Nesse caso o aumento no valor da condutividade é atribuído à adição da solução salina às águas infiltradas.

Outra confirmação de que as águas injetadas na caixa de infiltração alcançaram o poço escavado está no fato de que se observou gotejamento na interface entre o contato do aterro e o solo natural no poço escavado, cerca de uma hora depois do início do ensaio.

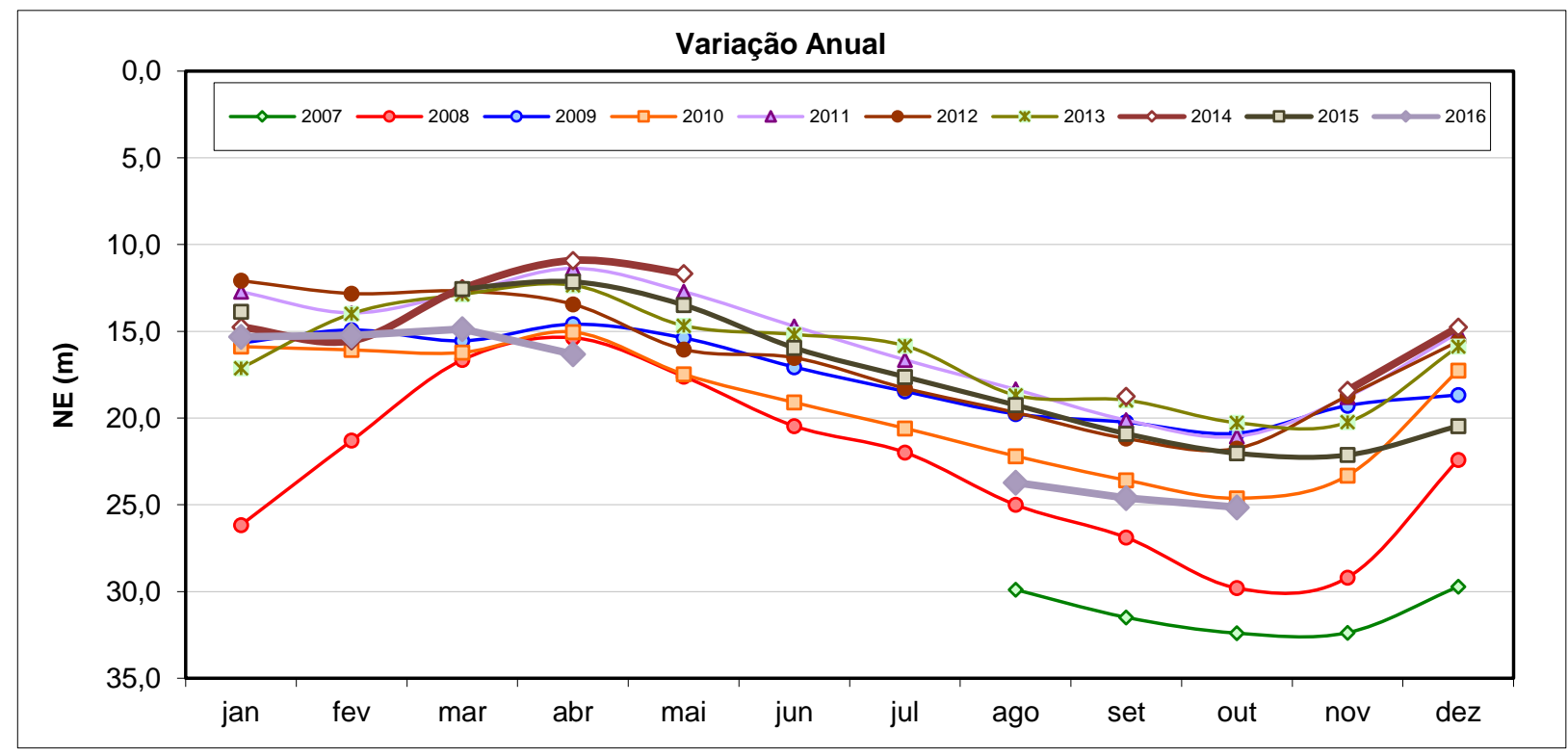

Figura 3.7-Série histórica da CAESB. Dados do poço SD 01 situado próximo ao Sistema Piloto de Recarga I. 


\begin{tabular}{|c|c|c|c|c|c|c|c|}
\hline 08/10/2016 & \multicolumn{3}{|c|}{ PARÂMETROS } & 08/10/2016 & \multicolumn{3}{c|}{ PARÂMETROS } \\
\hline HORA & T $\left({ }^{\circ} \mathrm{c}\right)$ & PH & CE $(\mu \mathrm{S})$ & HORA & T $\left({ }^{\circ} \mathrm{c}\right)$ & PH & CE $(\mu \mathrm{S})$ \\
\hline $09: 55$ & 23,5 & 8,4 & 80,6 & $13: 55$ & 24,3 & 8,28 & 103,2 \\
\hline $10: 10$ & 23,6 & 8,48 & 78,6 & $14: 10$ & 24,3 & 8,36 & 103,5 \\
\hline $10: 25$ & 24,1 & 8,54 & 78,9 & $14: 25$ & 25 & 8,47 & 101,9 \\
\hline $10: 40$ & 23,9 & 8,37 & 81,7 & $14: 40$ & 24,7 & 8,6 & 100,1 \\
\hline $10: 55$ & 23,9 & 8,35 & 83,9 & $14: 55$ & 24,6 & 8,61 & 102,3 \\
\hline $11: 10$ & 23,9 & 8,36 & 87 & $15: 10$ & 24,8 & 8,49 & 101,3 \\
\hline $11: 25$ & 23,9 & 8,34 & 89,9 & $15: 25$ & 24,8 & 8,45 & 101,8 \\
\hline $11: 40$ & 23,7 & 8,22 & 91,5 & $15: 40$ & 24,6 & 8,37 & 102 \\
\hline $11: 55$ & 23,9 & 8,28 & 97,6 & $15: 55$ & 24,2 & 8,35 & 102,2 \\
\hline $12: 10$ & 23,9 & 8,3 & 100,4 & $16: 10$ & 24,1 & 8,35 & 104,8 \\
\hline $12: 25$ & 23,9 & 8,31 & 100,9 & $16: 25$ & 23,9 & 8,44 & 104,8 \\
\hline $12: 40$ & 23,9 & 8,31 & 103,1 & $16: 40$ & 23,9 & 8,32 & 104,6 \\
\hline $12: 55$ & 24 & 8,33 & 102,9 & $16: 55$ & 23,7 & 8,36 & 104,8 \\
\hline $13: 10$ & 23,9 & 8,28 & 103,4 & $17: 10$ & 23,5 & 8,29 & 105,3 \\
\hline $13: 25$ & 23,9 & 8,27 & 103,6 & $17: 25$ & 23,5 & 8,32 & 104,7 \\
\hline $13: 40$ & 24,1 & 8,29 & 103,3 & $17: 40$ & 23,5 & 8,2 & 104,8 \\
\hline
\end{tabular}

Tabela 3.9 - Resultados das análises feitas na água do poço escavado do Projeto Piloto II. O valor da CE antes do início da injeção variou entre 78,6 e $81 \mu \mathrm{S}$.

\section{4 - ESTIMATIVAS DOS VOLUMES PASSÍVEIS DE RECARGA NO CONDOMÍNIO SAN DIEGO E PRIVÊ}

A primeira providência adotada para estimar os volumes passíveis de recarga nos dois condomínios foi a verificação da área de cobertura lote a lote, utilizando geoprocessamento. Neste caso foi avaliada a possibilidade técnica e logística para construção de caixas de infiltração e na sequência delimitaram-se com polígono as coberturas das construções internas a esses lotes com o objetivo de se obter a área dessas coberturas.

As imagens foram elaboradas utilizando o software ArcGis e no final obteve-se uma tabela com as áreas das coberturas das construções nos lotes selecionados que apresentavam espaço para construção de caixas de infiltração (dados em anexo).

\subsection{1 - CÁLCULO DOS VOLUMES ESTIMADOS DE RECARGA ARTIFICIAL POTENCIAL NO CONDOMÍNIO SAN DIEGO}

Foram identificados 280 lotes que apresentam as condições para instalação de caixas de infiltração, portanto são passíveis de fazer recarga das águas da chuva captadas a partir dos telhados e direcionadas para as caixas de infiltração. Na sequência foram delimitadas as coberturas das construções e então se obteve um valor total de $\mathbf{6 1 . 4 2 3} \mathbf{~ m}^{2}$ para as áreas cobertas dos lotes 
(Figura 3.8).

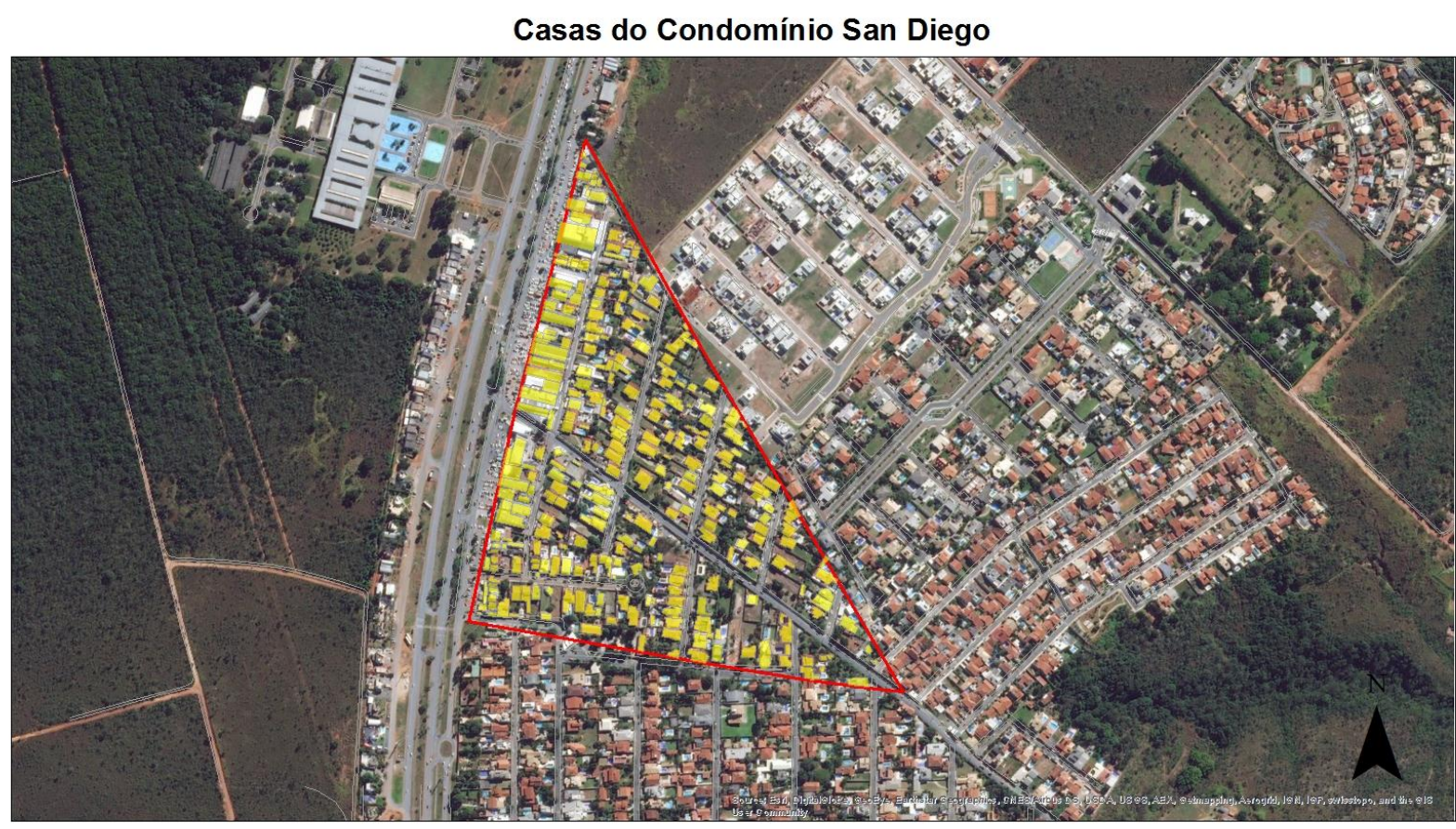

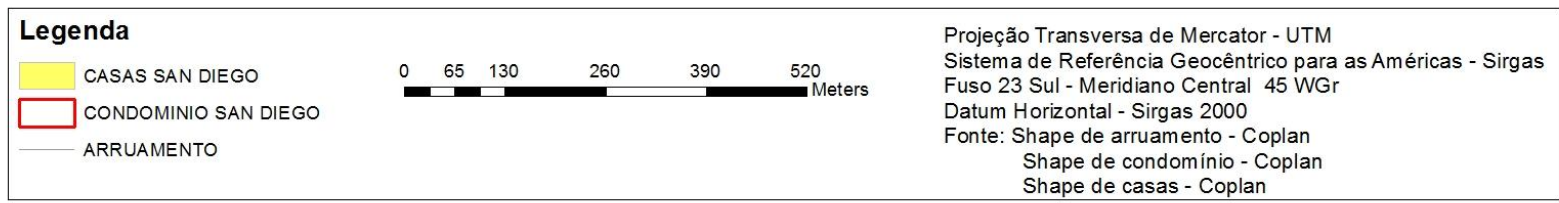

Figura 38 - Imagem da poligonal do Condomínio San Diego mostrando as coberturas das residências com sombreamento em amarelo.

Para os cálculos dos volumes de recarga potencial, utilizou-se a fórmula:

\section{$\operatorname{Rp}_{S D}=$ PP Liq $x$ Área de coberturas, onde:}

RpsD - Recarga artificial potencial no Condomínio San Diego

PP Liq - Precipitação pluviométrica anual líquida = $1000 \mathrm{~mm} /$ ano (considerando perdas por evapotranspiração e o fluxo interno);

Área de coberturas - Total das áreas dos polígonos das coberturas das construções.

$\mathbf{R p}=1000 \mathrm{~mm} /$ ano $\times$ 61.423,56 $\mathrm{m}^{2}=1 \mathrm{~m} /$ ano $\times$ 61 423,56 $\mathrm{m}^{2}=\mathbf{6 1 . 4 2 3 , 5 6} \mathbf{~ m}^{\mathbf{3}} / \mathbf{a n o}$.

Considerando que nem todos os lotes tenham suas caixas de infiltração construídas ou tenham viabilidade técnica para a instalação dos sistemas de recarga serão considerados dois cenários realistas para a máxima recarga na região: 40 e 60\% da área de cobertura de residências. Assim, no primeiro cenário seria possível adicionar por recarga artificial um volume da ordem de $\mathbf{2 4 . 5 6 9}$ $\mathbf{m}^{3}$ /ano. Para um cenário mais otimista, considerando $60 \%$ de implantação dos sistemas de recarga artificial, o volume potencial de recarga poderia alcançar $36.854 \mathrm{~m}^{3} / \mathbf{a n o}$. 


\subsection{2 - CÁLCULO DOS VOLUMES ESTIMADOS DE RECARGA POTENCIAL NO CONDOMÍNIO PRIVÊ}

Foram identificados 422 lotes que apresentam as condições para instalação de caixas de infiltração, portanto são passíveis de fazer recarga das águas da chuva captadas a partir dos telhados e direcionadas para as caixas de infiltração. Na sequência foram delimitadas por

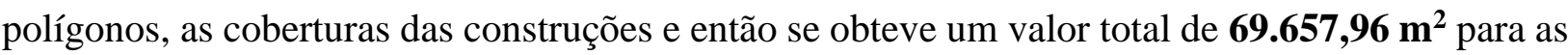
áreas cobertas dos lotes (Figura 3.9).

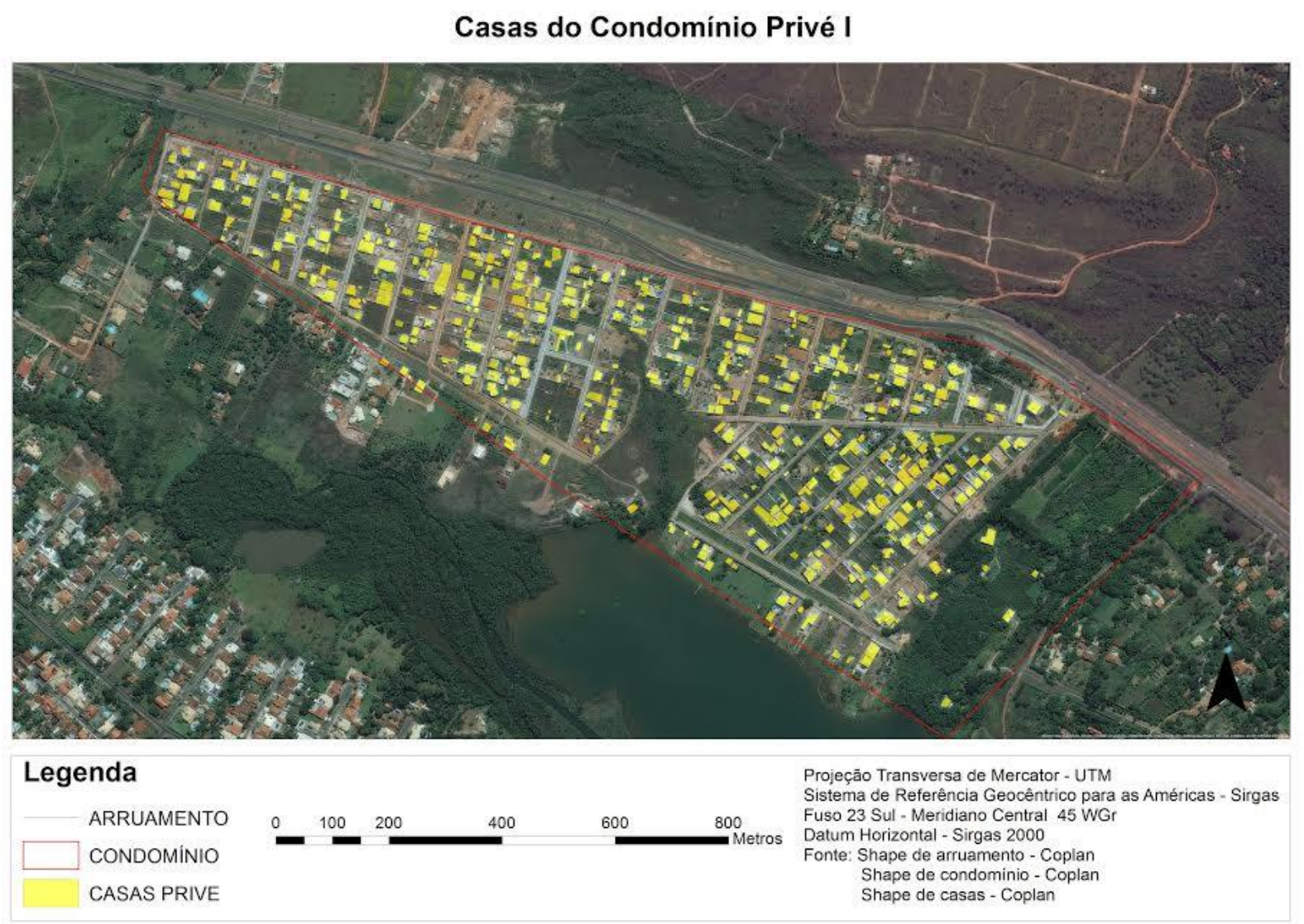

Figura 39 - Imagem da poligonal do Condomínio Privê Lago Norte mostrando as coberturas das casas em amarelo.

Para os cálculos dos volumes de recarga potencial, utilizou-se a equação:

RpP $=$ PP Liq $x$ Área de coberturas, onde:

Rpp - Recarga potencial Condomínio Privê;

PP Liq - Precipitação pluviométrica anual líquida= $1000 \mathrm{~mm} / \mathrm{ano}$ (considerando as perdas por evapotranspiração e por fluxo interno);

Área de coberturas - Total das áreas dos polígonos das coberturas das construções.

$\mathbf{R p}=1000 \mathrm{~mm} /$ ano $\times 69.657,96 \mathrm{~m}^{2}=1 \mathrm{~m} / \mathrm{ano} \times 69.657,96 \mathrm{~m}^{2}=\mathbf{6 9 . 6 5 7} \mathbf{~ m}^{3} / \mathbf{a n o}$

Considerando que nem todos os lotes tenham suas caixas de infiltração construídas e que sejam inseridos nos projetos de recarga artificial, serão utilizados dois cenários: um percentual de 
$40 \%$ para se obter um volume mais conservador, ou seja, da ordem de $27.863 \mathbf{~ m}^{3} / \mathbf{a n o}$. E um cenário mais otimista, considerando que $60 \%$ dos lotes implantem o sistema de recarga artificial, o que resulta em um volume potencial de recarga de $41.794 \mathrm{~m}^{3} / \mathbf{a n o}$.

\section{5 - ESTIMATIVAS DE RESERVAS RENOVÁVEIS E PERMANENTES}

\subsection{1 - RESERVAS RENOVÁVÉIS}

Reservas renováveis ou reservas reguladoras representam os volumes de água de tempo de circulação restrito (geralmente equivalente a um ciclo hidrológico $=12$ meses) que anualmente realimentam o sistema aquífero a partir das áreas de recarga. Para aquíferos fraturados este volume é geralmente importante, sendo estimado com base na parcela de infiltração que a cada ano alcança efetivamente as zonas fraturadas profundas, e que pode ser obtido com base no balanço hídrico climatológico local.

\subsubsection{1 - Projeto Piloto I}

Para o cálculo das estimativas de recargas anuais é necessário conhecer as reservas renováveis do Subsistema $\mathbf{R}_{\mathbf{3}} / \mathbf{Q}_{\mathbf{3}}$ domínio fraturado que ocorre na região do Condomínio San Diego.

As reservas reguladoras do meio fraturado serão estimadas a partir da consideração de que esses aquíferos são alimentados diretamente pelas águas infiltradas no meio intergranular sobreposto. Assim, será considerado percentual para o Subsistema $\mathbf{R}_{\mathbf{3}} / \mathbf{Q}_{\mathbf{3}}$, em virtude do grau de fraturamento interconectado, que facilita a percolação das águas e consequente transferência das águas rasas para os meios mais profundos (Campos et al., 2007).

O valor total da área do condomínio considerado foi da ordem de $215.799 \mathrm{~m}^{2}$. As áreas permeáveis do Condomínio estão relacionadas aos espaços verdes onde é possível ocorrer infiltração efetiva e considerou-se $20 \%$ da área total.

O valor da variação do nível freático foi obtido considerando os dados históricos fornecidos pela CAESB de 2008 a 2016 (Tabela 3.10), para o poço SD-01 do Condomínio San Diego, cujo resultado obtido foi de 9,06 m (Figura 3.7).

O índice de fraturas ( $\mathrm{I}_{\mathrm{fi}}$ ) do Subsistema $\mathbf{R}_{\mathbf{3}} / \mathbf{Q}_{\mathbf{3}}$ considerado foi da ordem de 3\%. Segundo Campos et al., (2007) os valores dos índices de fraturas interconectadas são definidos com base:

- na comparação com rochas similares que sofreram processo tectônico similar,

- por medidas de aberturas de fraturas em afloramentos,

- pelo comportamento reológico dos diferentes materiais que compõem as rochas e

- a partir das vazões médias de cada aquífero.

Foram realizados os cálculos das reservas renováveis para a área permeável do Condomínio San Diego, utilizando-se a fórmula abaixo:

$\mathbf{R r q}=\mathbf{A p} \cdot \Delta \mathbf{h} . \mathbf{I}_{\mathbf{f}}$ 
Onde:

Rrq - Reservas renováveis do $\mathrm{Q}_{3}$;

Ap - Área permeável $=20 \%$ da área total do Condomínio $=43.159,8 \mathrm{~m}^{2}$

$\Delta \mathbf{h}$ - Variação média do nível freático (2008 a 2016) =9,06 m

$\mathbf{I}_{\mathbf{f i}}$ - Índice de fraturas interconectadas do Subsistema $\mathbf{R}_{\mathbf{3}} / \mathbf{Q}_{\mathbf{3}}=3 \%$

Aplicando os valores acima na fórmula $\mathrm{Rr}=\mathrm{Ap} . \Delta \mathrm{h} . \mathrm{I}_{\mathrm{fi}}$, tem-se:

$\mathbf{R r}=43.159,8 \times 9,06 \times 0,03=11.730 \mathrm{~m}^{3}$

$\operatorname{Rr}=11.730 \mathrm{~m}^{3} /$ ano

\begin{tabular}{|c|c|c|c|c|c|c|c|c|c|c|c|c|}
\hline SD-01 & jan & fev & mar & abr & mai & jun & jul & ago & set & out & nov & dez \\
\hline 2007 & & & & & & & & 29,89 & 31,49 & 32,40 & 32,37 & 29,72 \\
\hline 2008 & 26,17 & 21,30 & 16,65 & 15,37 & 17,60 & 20,46 & 21,98 & 25,00 & 26,89 & 29,80 & 29,19 & 22,41 \\
\hline 2009 & 15,67 & 14,92 & 15,55 & 14,59 & 15,38 & 17,06 & 18,46 & 19,76 & 20,24 & 20,88 & 19,28 & 18,67 \\
\hline 2010 & 15,88 & 16,07 & 16,22 & 15,04 & 17,47 & 19,10 & 20,59 & 22,19 & 23,58 & 24,62 & 23,31 & 17,26 \\
\hline 2011 & 12,72 & 13,94 & 12,77 & 11,37 & 12,71 & 14,71 & 16,64 & 18,35 & 20,12 & 21,06 & 18,78 & 15,07 \\
\hline 2012 & 12,08 & 12,82 & 12,68 & 13,44 & 16,04 & 16,52 & 18,28 & 19,68 & 21,18 & 21,75 & 18,72 & 15,58 \\
\hline 2013 & 17,12 & 13,98 & 12,87 & 12,34 & 14,67 & 15,18 & 15,83 & 18,68 & 18,97 & 20,27 & 20,24 & 15,88 \\
\hline 2014 & 14,75 & 15,54 & 12,53 & 10,91 & 11,66 & & & & 18,74 & & 18,40 & 14,76 \\
\hline 2015 & 13,86 & & 12,56 & 12,14 & 13,48 & 15,95 & 17,62 & 19,25 & 20,90 & 22,03 & 22,13 & 20,46 \\
\hline 2016 & 15,32 & 15,23 & 14,87 & 16,31 & & & & 23,72 & 24,61 & 25,14 & & \\
\hline
\end{tabular}

Tabela 3.10 - Dados dos níveis de água do poço SD 01, próximo ao Sistema Piloto de Recarga ISérie histórica da CAESB

O volume estimado para as reservas renováveis de aquíferos fraturados, obtido acima, segundo Campos et al. (2007), é geralmente importante, sendo estimado com base na parcela de infiltração que a cada ano alcança efetivamente as zonas fraturadas profundas, e que pode também ser obtido com base no balanço hídrico climatológico local.

\subsubsection{2 - Projeto Piloto II}

Para o cálculo das estimativas de recargas anuais é necessário conhecer as reservas renováveis do Subsistema A, domínio fraturado que ocorre na região do Condomínio Privê. As reservas renováveis ou reservas reguladoras representam os volumes de água de tempo de circulação restrito (geralmente equivalente a um ciclo hidrológico $=12$ meses) que anualmente realimentam o sistema aquífero a partir das áreas de recarga (Campos et al., 2007). 


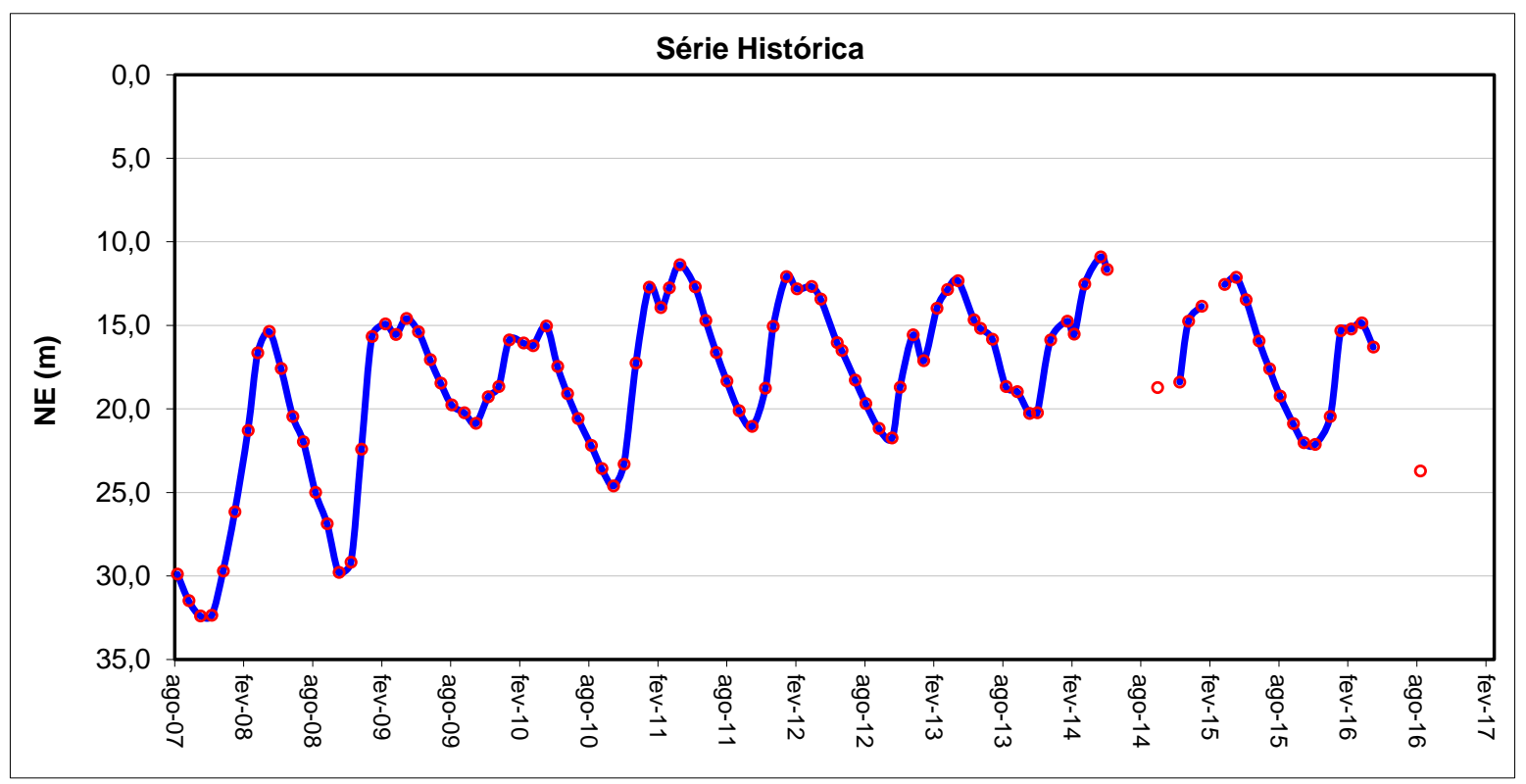

Figura 3.10 - Série histórica da CAESB. Dados dos níveis de água do poço SD 01, próximo ao Sistema Piloto de Recarga I.

No caso desse Subsistema, considerou-se a mesma metodologia utilizada para o Condomínio San Diego, ou seja, obteve-se a área total do condomínio de cerca de 730.067,12 $\mathrm{m}^{2}$ e $20 \%$ desse valor para área permeável que equivalem a 146.013,424 $\mathrm{m}^{2}$ e como índice de faturamento interconectado $0,5 \%$. Para o valor de $\Delta \mathrm{h}$, utilizou-se o índice pluviométrico médio anual para o Distrito Federal que é da ordem de 1,00 m/ano.

Foram realizados os cálculos das reservas renováveis para a área permeável do Condomínio Prive, utilizando-se a fórmula abaixo:

$\mathbf{R}_{\mathbf{r A}}=\mathbf{A p} \times \mathbf{I}_{\mathrm{pDF}} \mathbf{x} \mathbf{I}_{\mathbf{f i}}=146.013 \mathrm{~m}^{2} \times 1,00.10^{-3} \mathrm{~km} / \mathrm{ano} \times 0,05$

$\mathbf{R}_{\mathrm{rA}}=7.300 \mathrm{~m}^{3} / \mathrm{ano}$

Onde:

$\mathbf{R}_{\mathbf{r A}}$ - Reservas Renováveis do Subsistema A

Ap - $20 \%$ da Área total do Condomínio Privê

$\mathbf{I}_{\mathrm{pDF}}$ - Índice Pluviométrico médio Anual do DF (considerando perdas por evapotranspiração e o

fluxo interno);

$\mathbf{I}_{\mathbf{f i}}$ - Índice de fraturamento interconectado

\subsection{2 - RESERVAS PERMANENTES}

Reservas permanentes ou reservas seculares (reservas de saturação) correspondem ao volume de água que ocupa os espaços livres abaixo no nível mínimo da zona não saturada do aquífero. Para os aquíferos fraturados, é equivalente a todo o volume de água que preenche fissuras interconectadas abaixo do nível de saturação mínimo. Para os sistemas intergranulares corresponde a água que ocupa a porosidade (Campos et al., 2007). 
A metodologia adotada por Campos et al., (2007), para o cálculo das reservas permanentes dos meios fraturados que apresentam índice de fraturas interconectadas que diminuem com o aumento da profundidade, considerou o cálculo das reservas permanentes para dois intervalos. A reserva total para cada subsistema será a soma dos dois intervalos. Para o intervalo mais raso será utilizado um índice de interconectividade de $0,5 \%$ e para o intervalo mais profundo, ou seja, onde as fraturas tendem a se fechar o índice adotado será de $0,3 \%$.

Ainda de acordo com Campos et al (2007), os valores dos índices de fraturas interconectadas foram definidos com base:

- na comparação com rochas similares que sofreram processo tectônico similar,

- por medidas de aberturas de fraturas em afloramentos,

- pelo comportamento reológico dos diferentes materiais que compõem as rochas e

- a partir das vazões médias de cada aquífero

\begin{tabular}{|c|c|c|c|c|c|c|c|c|}
\hline $\begin{array}{c}\text { Domínio Fraturado } \\
\text { Subsistema }\end{array}$ & $\begin{array}{c}\text { Início do } \\
\text { Intervalo }\end{array}$ & $\begin{array}{c}\text { Fim do } \\
\text { Intervalo }\end{array}$ & $\Delta \mathbf{b}(\mathbf{m})$ & $\mathbf{I}_{\mathbf{f i}}(\boldsymbol{\%})$ & $\begin{array}{c}\text { Início } \\
\text { Intervalo }\end{array}$ & $\begin{array}{c}\text { Fim } \\
\text { Intervalo }\end{array}$ & $\boldsymbol{\Delta} \mathbf{b}(\mathbf{m})$ & $\mathbf{I}_{\mathbf{f i}}(\boldsymbol{\%})$ \\
\hline Subsistema $\mathbf{R}_{\mathbf{3}} / \mathbf{Q}_{\mathbf{3}}$ & 50 & 120 & 70 & 3,5 & 120 & 180 & 60 & 2,0 \\
\hline Subsistema $\mathbf{A}$ & 40 & 90 & 50 & 0,5 & 90 & 140 & 50 & 0,3 \\
\hline
\end{tabular}

Tabela 3.11 - Parâmetros utilizados para as estimativas das reservas hídricas nos subsistemas aquíferos fraturados na região dos Condomínios San Diego e Privê, respectivamente (Campos et al., 2007).

Para o cálculo das reservas permanentes dos dois subsistemas: Subsistema $\mathbf{R}_{\mathbf{3}} / \mathbf{Q}_{\mathbf{3}}$ e Subsistema $\mathbf{A}$ foram utilizadas as seguintes equações:

$\mathrm{R}_{\mathrm{pQ}}=\mathbf{A}_{\mathrm{SD}} \mathbf{x} \mathbf{b} \mathbf{x} \mathbf{I}_{\mathrm{fi}}, \quad$ Onde :

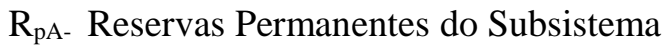
$\mathbf{R}_{3} / \mathbf{Q}_{3}$

A $\mathrm{SD}$ - Área do Condomínio San Diego

b - Espessura da zona saturada

$\mathrm{I}_{\mathrm{fi}}$ - Índice de fraturamento interconectado
$\mathrm{R}_{\mathbf{p A}}=\mathbf{A}_{\mathbf{P}} \mathbf{x} \mathbf{b} \mathbf{x} \mathbf{I}_{\mathbf{f i}}, \quad$ Onde :

$\mathrm{R}_{\mathrm{pA}}$ - Reservas Permanentes do Subsistema A

AP - Área do Condomínio Privê

b - Espessura da zona saturada

$\mathrm{I}_{\mathrm{fi}}$ - Índice de fraturamento interconectado

Os resultados obtidos para as reservas permanentes do domínio fraturado para os dois Subsistemas são:

\section{Projeto Piloto de Recarga I- Condomínio San Diego}

Subsistema $\mathbf{R}_{\mathbf{3}} / \mathbf{Q}_{\mathbf{3}} \mathbf{1}=215.799,52 \mathrm{~m}^{2} \times 70 \mathrm{~m} \times 0,035=528.708,82 \mathrm{~m}^{3}$;

Subsistema $\mathbf{R}_{\mathbf{3}} / \mathbf{Q}_{\mathbf{3}} \quad 2=215.799,52 \mathrm{~m}^{2}$ x $60 \mathrm{~m} \times 0,02=258.959,42 \mathrm{~m}^{3}$;

Subsistema $\mathbf{R}_{3} / \mathbf{Q}_{3}$ T $=\mathbf{7 8 7 . 6 6 8 , 2 4} \mathbf{~ m}^{3}$. 
Projeto Piloto de Recarga II- Condomínio Privê

Subsistema A $1=730.067 .12 \mathrm{~m}^{2}$ x $50 \mathrm{~m}$ x 0,005 $=182.516,78 \mathrm{~m}^{3}$ Subsistema $\mathbf{A}_{2}=730.067 .12 \mathrm{~m}^{2} \times 50 \mathrm{~m} \times 0,003=109.510,07 \mathrm{~m}^{3}$ Subsistema $A_{\mathrm{T}}=\mathbf{2 9 2 . 0 2 6 , 8 5 \mathbf { ~ m } ^ { 3 }}$ 


\section{CAPÍTULO 4}

\section{DISCUSSÕES}

\section{1 - ANÁLISE QUALITATIVA DOS RESULTADOS}

O fluxo da água subterrânea se dá pela migração da água pela rocha ou solo através de seus espaços interconectados e é controlado pelo gradiente e a carga hidráulica. No caso específico da área em estudo o fluxo se inicia pela porosidade intergranular dos solos e migra para as descontinuidades das rochas representadas por fraturas, plano de acamamento e planos de foliação (Campos \& Cunha, 2015).

Na região do Sistema de Recarga Piloto I, o modelo de circulação das águas subterrâneas proposto envolve três sistemas de fluxo hidrogeológico: fluxo rápido por higroscopia (setas pretas), fluxo interno (setas azuis) e fluxo em fratura (setas vermelhas). A Figura 4.1 apresenta os fluxos em duas dimensões, entretanto é necessário observar que o fluxo é um fenômeno tridimensional.

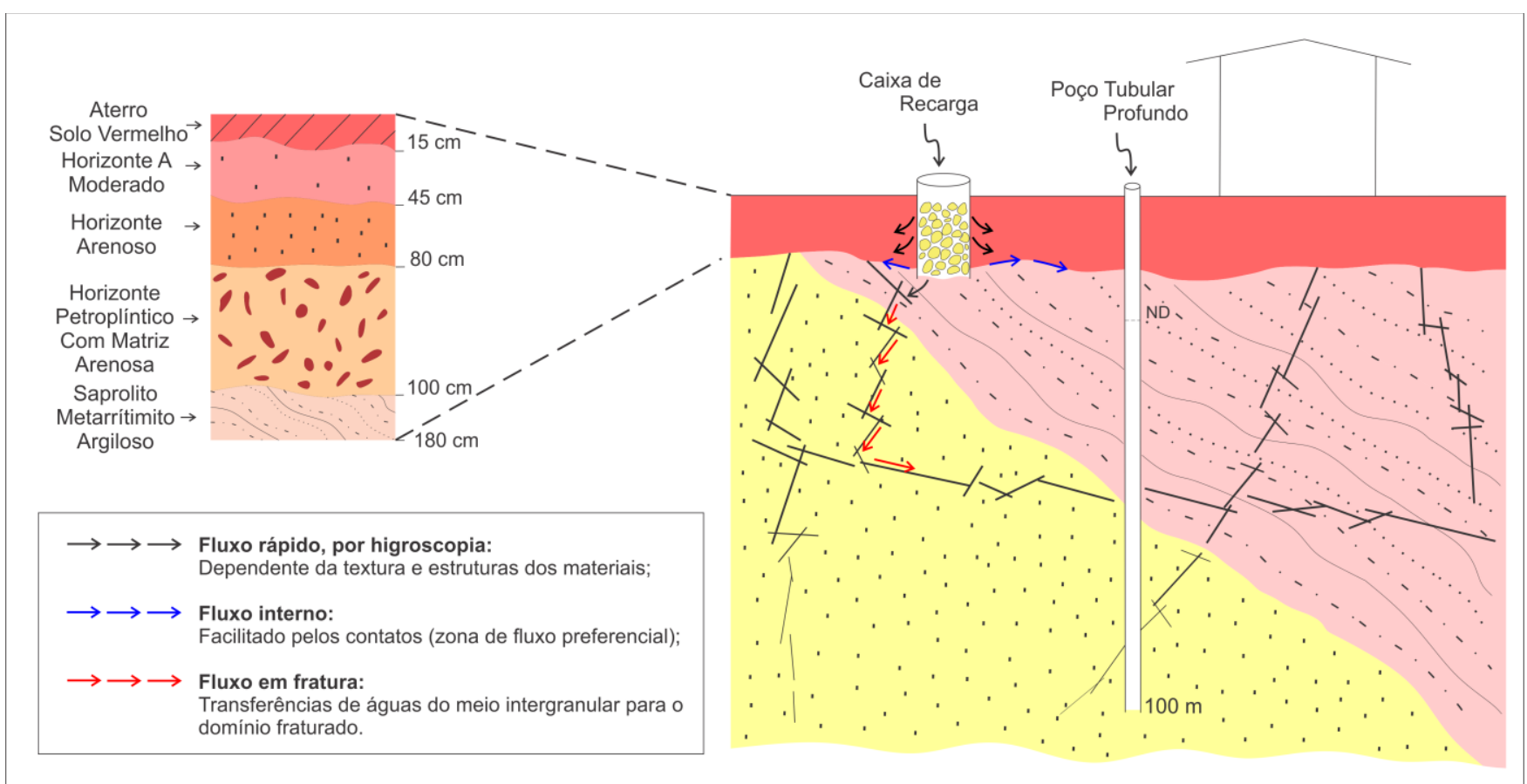

Figura 4. 1 - Representação esquemática das condições de circulação das águas subterrâneas a partir de caixa de recarga artificial (Projeto de Recarga Piloto I).

Conforme discutido anteriormente no item Metodologia desta dissertação o sistema de recarga por caixas de infiltração prevê a infiltração lateral em interfaces de horizontes de solos ou no contato saprolito-rocha e infiltração vertical e lateral ao logo das fraturas abertas em rocha fresca.

$\mathrm{Na}$ área de estudo o fluxo rápido por higroscopia acontece no domínio poroso e depende da textura, estrutura e umidade do meio por onde a água percola. Podem-se citar alguns fatores que favorecem esse fluxo rápido, incluindo: o perfil de alteração que consiste de horizontes contendo 
matriz arenosa e a época de estiagem em que foram realizadas as injeções. Isso permitiu maior absorção da água por higroscopia, uma vez que o perfil se encontrava seco ou com baixa umidade.

O fluxo interno é caracterizado por ocorrer na zona preferencial de contatos entre litologias que apresentam valores de condutividade hidráulica contrastante. Na área estudada este tipo de fluxo se dá na interface do horizonte petroplíntico arenoso e o saprolito do metarritmito argiloso.

O fluxo em fratura ocorre quando há transferência de águas do meio intergranular para o domínio fraturado conforme sugere o Modelo de Única Superfície Potenciométrica sem Confinamento (Figura 2.8) proposto para a área estudada, que considera a existência de uma região com fraturas abertas diretamente sob a seção de solo/saprolito que pode permanecer saturada no período das chuvas e drenar na época de recessão das chuvas.

As nascentes do Ribeirão Taboca que tiveram suas águas amostradas neste estudo (Figura 3.3) constituem uma forma de descarga dos sistemas aquíferos a montante e podem ser classificadas como do tipo contato sendo exutórios do aquífero freático e ocorrem na interface entre os solos e a rocha alterada (em função do importante contraste de condutividade hidráulica). O outro tipo são as nascentes de fratura e estão relacionadas aos maiores planos de fraturamento das rochas. $\mathrm{O}$ padrão retangular das drenagens formadas por algumas dessas nascentes atesta seu condicionamento pelas estruturas das rochas.

O padrão de relevo, a razão profundidade / largura da bacia e a distância entre a área de descarga em relação à área de recarga definem se o fluxo é local, intermediário ou regional (Fetter, 2004). Essas nascentes por estarem próximas às áreas de recarga são alimentadas pelo fluxo subterrâneo local. Este sistema de fluxo apresenta maior circulação e requer elevado gradiente topográfico, o que é observado na área de estudo.

Estudos realizados por Campos \& Cunha (2015) em uma região semelhante à área em estudo com mesmo padrão geológico, hidrogeológico e geomorfológico, onde o fluxo da água subterrânea do domínio fraturado ocorre principalmente ao longo do Subsistema $\mathbf{R}_{\mathbf{3}} / \mathbf{Q}_{\mathbf{3}}$ considera a existência de um fluxo regional, além de fluxos local e intermediário. Entretanto, o sistema de fluxo regional está vinculado a fraturas mais profundas, que aparentemente não ocorrem na área em estudo.

Para a área do Sistema de Recarga Piloto II, o modelo de circulação das águas subterrâneas envolve os mesmos três tipos de fluxos propostos para o Piloto I: fluxo rápido por higroscopia (setas pretas), fluxo interno (setas azuis) e fluxo em fratura (setas vermelhas). A Figura 4.2 mostra o padrão de fluxo bidimensional. Neste caso o fluxo no contato entre o aterro e o horizonte superficial natural é predominante.

Da mesma forma, o fluxo rápido por higroscopia ocorre umedecendo a região do aterro ao redor da caixa de infiltração e preenchendo os poros do meio freático não saturado.

As linhas de fluxo interno acontecem em duas interfaces, na interface do aterro com o solo natural e na interface do saprolito com a rocha alterada (Figura 4.2). O gotejamento observado no 
poço escavado, entre a interface do aterro e o solo natural durante o ensaio de injeção atesta esse comportamento do fluxo interno. Há ainda as linhas de fluxo em fraturas que transferem água do meio poroso para o domínio fraturado.

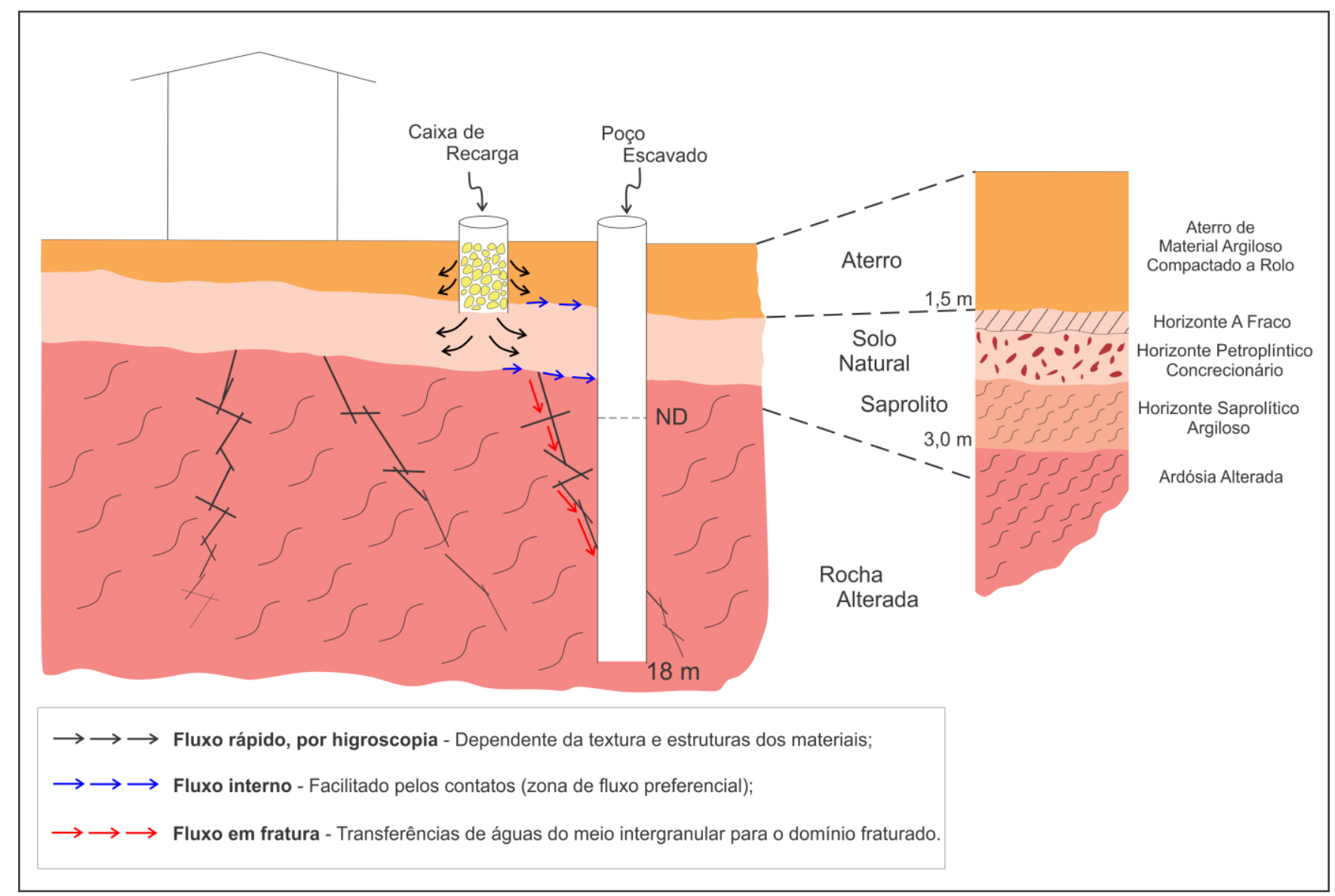

Figura 4.2 - Representação esquemática de modelo de circulação das águas subterrâneas proposto para o Projeto de Recarga Piloto II.

Mesmo não se conhecendo os caminhos que as águas infiltradas nas caixas de recarga percorrerão nos diferentes meios deve-se considerar que a maior parte deverá seguir até as zonas saturadas em maior profundidade, pois as perdas por evapotranspiração deverão ser muito restritas, pois a infiltração já se inicia a uma profundidade abaixo da maior parte das zonas de raízes. Desta forma é importante afirmar que as águas inseridas nos sistemas de recarga mesmo que por diferentes direções e sentidos de fluxo, em sua maior parte irão se integrar ao ambiente hidrogeológico e deverão favorecer a recarga e diluição de eventuais cargas contaminantes presentes nos aquíferos.

\section{2 - ANÁLISE QUANTITATIVA DOS RESULTADOS}

Os ensaios hidráulicos realizados no Projeto de Recarga Piloto I permitiram que fosse injetado um volume total de 38.500 litros de água na caixa de infiltração com monitoramento a fim de se 
obter um valor de vazão médio para a capacidade de infiltração.

No ensaio do dia 10/10/2016 quando foi possível injetar 15.000 L de água em um período de 4 horas e 20 minutos obteve-se uma vazão média para o sistema da ordem de $3.400 \mathrm{~L} / \mathrm{h}$ para uma caixa de infiltração com formato cilíndrico e dimensões de 1,0 m de diâmetro por 1,80 m de profundidade, com capacidade total de $1.413 \mathrm{~L}$ ou de cerca de $565 \mathrm{~L}$, considerando uma porosidade de $40 \%$.

Quando se compara o valor da vazão obtida no ensaio do dia 10, isto é, $3.400 \mathrm{~L} / \mathrm{h}$ com uma chuva de forte intensidade conclui-se que o sistema tem condições de funcionamento se for implantado nos lotes dos condomínios visando à captação da água das chuvas a partir dos telhados das edificações com destino à caixa de infiltração.

Um evento de precipitação anômalo com intensidade de $100 \mathrm{~mm} / \mathrm{h}$ corresponde a um volume acumulado de $100 \mathrm{~L} / \mathrm{h}$ para cada $\mathrm{m}^{2}$ de área de cobertura.

Precipitações da ordem de $100 \mathrm{~mm}$ em 24 horas apresentam recorrência da ordem de 10 anos, segundo os seguintes dados obtidos do sítio Climatempo (consulta em 15/11/2016): 99,6 mm no período entre 10 horas da manhã do dia 19 e 10 horas da manhã de 20 de janeiro de 2016; 103,1 mm entre os dias 26 e 27 de outubro de 2006 em Brasília e 102,2 mm no mesmo dia na região do Gama.

Na história de registros meteorológicos de Brasília, chuvas com intensidade maior que 100 $\mathrm{mm} / \mathrm{h}$ apenas foram observados em raros episódios, como, por exemplo, no dia 15 de novembro de 1963 quando se acumularam 122 mm em 24 horas de observação, ou no dia 31 de março de 1964 quando foram observados $115 \mathrm{~mm}$ em 24 horas (INMET).

A vazão obtida no ensaio de infiltração mencionado anteriormente corresponde a um grande volume que pode ser injetado na caixa de infiltração construída de acordo com os parâmetros já mencionados. É importante destacar que os métodos de recarga aplicados neste estudo podem ser utilizados para outras áreas de condomínios do DF, uma vez que a maioria desses condomínios está implantada em regiões de recarga regional dos sistemas aquíferos do DF, caracterizadas por solos espessos e permeáveis e condições construtivas de projetos residenciais que utilizam aterros espessos sobre solos rasos para nivelamento dos lotes.

Pode-se chegar à mesma conclusão para o Sistema de Recarga Piloto II quando se obteve uma vazão de $1000 \mathrm{~L} / \mathrm{h}$. O sistema de recarga implantado para o Subsistema A com aterros tende a apresentar boas condições de funcionamento, entretanto, com uma capacidade menor de infiltração se comparado aos solos naturais mais arenosos e mais espessos.

\section{3 - ANÁLISE DA CAPACIDADE DE RECARGA E CENÁRIOS FUTUROS}

Os cálculos realizados para se obter o volume estimado de recarga consideraram os lotes onde 
foi possível observar espaço para implantação de caixa de infiltração para permitir recarga a partir da captação das águas da chuva provenientes de seus telhados.

Vale ressaltar que todos os parâmetros utilizados nos cálculos foram subestimados com o intuito de que os resultados obtidos fossem conservadores. Foram considerados dois cenários: 40 e $60 \%$ das residências instalando os sistemas de recarga artificial. As áreas de coberturas foram obtidas a partir de imagens de satélite de alta resolução e foi considerado que dos 1500 mm anuais de precipitação $1000 \mathrm{~mm}$ corresponderiam à recarga líquida, isto é, eliminando-se as perdas por evapotranspiração, fluxo interno, defeitos construtivos nos sistemas, eventuais transbordamentos das caixas, dentre outros.

Para o Sistema de Recarga Piloto I, Condomínio San Diego, considerando um Cenário1 no qual $40 \%$ dos lotes implantem a recarga artificial obtém-se um volume de $\mathbf{2 4 . 5 6 9 , 4 2} \mathbf{~ m}^{\mathbf{3}}$ por ano. Esse valor supera o cálculo realizado para recarga natural das reservas renováveis do Subsistema $\mathbf{R}_{\mathbf{3}} / \mathbf{Q}_{3}$ quando se obteve um volume $\mathbf{1 1 . 7 3 0 , 8 6} \mathbf{~ m}^{\mathbf{3}}$ considerando um percentual de apenas $20 \%$ da área total do referido condomínio como área permeável, ou seja, passível de infiltração de águas

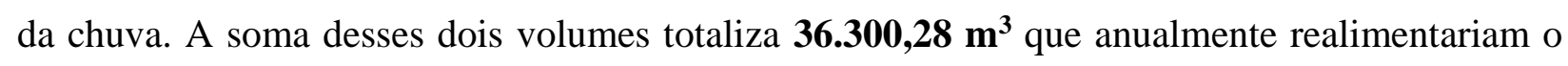
sistema aquífero a partir da recarga natural e da recarga artificial nas caixas de infiltração construídas nesses lotes.

Para um Cenário 2, mais otimista, considerou-se que 60\% dos lotes realizem a recarga artificial resultando em um volume de reserva renovável potencial da ordem de $\mathbf{4 8 . 5 8 5 , 0} \mathbf{~ m}^{3}$.

Para o Sistema de Recarga Piloto II, a análise é semelhante, ou seja, considerando que $40 \%$ das construções façam a recarga por meio das caixas de infiltração obtém-se $\mathbf{2 7 . 8 6 3 , 0 2} \mathbf{~ m}^{\mathbf{3}}$. Somando a esse valor de recarga potencial obtida pela utilização de caixas de infiltração ao volume das reservas reguladoras calculado para o Condomínio Privê de $7.300,67 \mathbf{~ m}^{3}$, obtém-se $35.163,69$ $\mathbf{m}^{\mathbf{3}}$ como recarga potencial para o Subsistema A, do Domínio Fraturado que ocorre no referido Condomínio.

Considerando que $60 \%$ dos lotes construam suas caixas de infiltração e façam recarga somando o volume dessa recarga potencial de 41.794,54 $\mathbf{m}^{3}$ com o volume da recarga anual calculado para $20 \%$ da área permeável do Condomínio, $7.300,67 \mathbf{~ m}^{3}$, obtém-se um volume total de 49.095,21 $\mathbf{~ m}^{3}$ que podem ser infiltrados e realimentar o Domínio Fraturado do Subsistema A.

Quando se faz uma análise do tempo necessário para alcançar eficiência da recarga nos ambientes de Chapadas Elevadas, onde ocorrem solos espessos e na Depressão do Paranoá com solos rasos e aterro, obtém-se o período de tempo em anos que as reservas renováveis vão recompor as reservas permanentes, favorecendo a diluição dos contaminantes presentes nas águas subterrâneas, melhorando dessa forma a qualidade das águas das nascentes, bem como o aumento da disponibilidade hídrica. 
Para o Condomínio San Diego, considerando que 40\% das construções façam recarga artificial das águas da chuva em caixas de infiltração obteve-se um período da ordem de 21 anos como tempo necessário para eficiência da recarga e consequente diluição dos contaminantes e para um cenário em que 60\% desenvolvam a recarga artificial obtém-se um período de tempo da ordem de 16 anos. Estas propostas de tempos médios para diluição consideram que, tanto as águas do aquífero freático, quanto as reservas do aquífero fraturado já estão contaminadas.

No caso do Condomínio Privê, considerando os mesmos cenários citados, obtém-se para 40\% das construções executando recarga artificial a partir das águas da chuva com qualidade de água potável, um período de tempo necessário de cerca de 10 anos e para $60 \%$ das construções fazendo recarga obtém-se um período de tempo de cerca de 7 anos para eficiência da recarga e diluição das cargas contaminantes.

\section{4 - CONSIDERAÇÕES FINAIS}

A qualidade da água bem como seu monitoramento constituem parâmetros importantes para a gestão adequada dos recursos hídricos. É com base na qualidade da água que é possível estabelecer os usos múltiplos para sua utilização racional.

Os resultados das análises do parâmetro nitrato na água coletada do poço SD 01 não apresentaram variação que demonstrasse alguma diluição desse contaminante como consequência da injeção de água por meio da caixa de infiltração. O que pode estar relacionado à ausência de conexão hidráulica entre o referido poço e a caixa de infiltração devido à presença de fraturas, do perfil construtivo do poço ou da declividade do topo rochoso. Embora a diluição não tenha sido constatada o fato é que um grande volume de água foi infiltrado na caixa de infiltração e realimentou os aquíferos subjacentes.

Embora os valores para o ânion nitrato tenham ficado bem abaixo do limite de potabilidade, ou seja, $10 \mathrm{mg} / \mathrm{L}$, a contaminação das nascentes da borda da chapada é indiscutível uma vez que as águas subterrâneas naturais do Distrito Federal não contêm nitrato. Vale destacar que a água retirada de dois poços internos ao condomínio apresentou índices próximos e acima do limite de potabilidade, respectivamente, 6,12 e $12,91 \mathrm{mg} / \mathrm{L}$.

A persistência e tendência de elevação desse parâmetro, observadas desde 2007 e demonstradas pelos dados da série histórica da CAESB, bem como pelos dados dos rótulos das garrafas de água mineral natural Hydrate revelam que a contaminação é efetiva e deve ser monitorada mesmo considerando que atualmente os condomínios estejam sendo atendidos pela coleta de esgoto. O nitrato é um composto muito móvel que representa o estágio final da oxidação da matéria orgânica. Os resíduos de produtos proteicos provenientes de esgotos, fezes e resíduos de animais são ricos em nitrogênio e se decompõem em nitrato na presença de oxigênio. $\mathrm{O}$ ciclo 
do nitrogênio envolve as transformações dos compostos nitrogenados na sequência: nitrogênio orgânico, amônia $\left(\mathrm{NH}_{3}\right)$, nitrito $\left(\mathrm{NO}_{2}\right)$ e nitrato $\left(\mathrm{NO}_{3}\right)$ (Mizuno, 2012). A presença do cloreto e do sódio nas águas amostradas e sua tendência de elevação também indicam contaminação por efluentes domésticos. Neste caso estes íons são derivados do sal de cozinha consumido em excesso pela população.

Vale ressaltar que nem todo Condomínio San Diego é atendido por coleta e tratamento de esgotos. Conforme foi discutido anteriormente, diversas casas, bem como as instalações da recepção ainda não tiveram seus sistemas de esgotamento in situ desativados. Segundo Whitehead \& Geary (2000), há risco potencial de contaminação quando houver 15 ou mais sistemas de esgotamento in situ/ $\mathrm{km}^{2}$ em uma região.

O presente estudo foi realizado em dois ambientes geomorfológicos característicos do Distrito Federal, ou seja, Chapadas Elevadas com solos espessos e Depressão do Paranoá com solos rasos e aterro, por apresentarem as condições em que se encontram localizados mais de $90 \%$ dos condomínios horizontais no Distrito Federal, portanto, os métodos de recarga artificial aplicados por este estudo podem ser utilizados para outras áreas de condomínios da região. Segundo Maimone (2004), a condição de recarga deve ser o principal parâmetro aplicado para a determinação da disponibilidade hídrica subterrânea para uma região.

Os resultados dos cálculos e estimativas de reservas realizados mostram que o volume de água que pode ser infiltrado para alimentar os aquíferos subjacentes por meio de recarga artificial é considerável, mesmo com a utilização de parâmetros subdimensionados. De acordo com Campos et al. (2007) a despeito da existência de equações e metodologias simples para o cálculo das reservas hídricas, a maior limitação é a definição dos parâmetros utilizados nos cálculos. Neste trabalho foram aplicados valores considerados adequados para os diferentes meios aquíferos.

Vale destacar que o índice pluviométrico utilizado para cálculo das reservas foi cerca de $67 \%$ do valor da média anual pluviométrica para o Distrito Federal que é de $1500 \mathrm{~mm}$, pois foram considerados as perdas potenciais por evapotranspiração e fluxo interno.

Foram utilizados ainda para os cálculos das reservas índices de fraturas interconectadas distintos para diferentes profundidades, uma vez que o referido índice diminui com o aumento da pressão de confinamento.

A aplicação de técnicas de recarga artificial de aquíferos no Distrito Federal é extremamente importante uma vez que as principais áreas de recarga natural regional dos mananciais subterrâneos, parte da região da Chapada de Brasília e da Contagem e suas adjacências estão ocupadas por condomínios horizontais. O objetivo da recarga artificial é compensar a redução do volume de infiltração de água no solo, ocasionada pela impermeabilização decorrente da ocupação. 
O Distrito Federal, por não apresentar grandes drenagens superficiais, tem nas águas subterrâneas uma fonte estratégica para o abastecimento de núcleos rurais e urbanos fora da área de atendimento da companhia de saneamento, e para manutenção das vazões desses cursos superficiais (Campos et al., 2007). Portanto, a prática de recarga artificial como uma ferramenta de gestão deve ser incentivada e ampliada.

A prática de recarga artificial é uma das iniciativas, dentre outras, sugerida por Campos et al., (2007) em sua proposta de gestão para o Distrito Federal, que apresenta alto potencial multiplicador e alta viabilidade, pois, uma significativa parte da população de usuários é representada por pessoas com bom nível de instrução o que facilita sua sensibilização e a implantação dessa iniciativa. 


\section{CAPÍTULO 5}

\section{CONCLUSÕES E RECOMENDAÇÕES}

\section{1 - CONCLUSÕES}

Após o desenvolvimento dos estudos, integrando os dados sobre a hidrogeologia, solos, relevo, testes hidráulicos, alguns dados de hidroquímica, áreas ocupadas por coberturas de edificações, áreas verdes e distribuição de chuvas as seguintes conclusões podem ser enumeradas:

- Os sistemas de recarga artificial propostos apresentam alta efetividade para induzir a infiltração de águas de chuvas coletadas nas coberturas de edificações em condomínios horizontais;

- Os volumes potenciais de infiltração, considerando diferentes cenários, são relevantes e podem auxiliar na remediação in situ de aquíferos contaminados em prazos variáveis entre 5 e 15 anos dependendo do grau de adesão da população e do meio físico local;

- A eficiência da recarga artificial pode ser definida pela capacidade máxima de infiltração nos diferentes sistemas de recarga e varia conforme os diferentes controles do meio físico local. Sobre solos naturais arenosos e mais espessos a capacidade de recarga artificial é maior que para os casos de aterros com uso de solos argilosos;

- As condições do meio físico da maior parte dos condomínios horizontais do Distrito Federal permitem que seja realizada a recarga artificial dos aquíferos. Como a ampla maioria destas ocupações urbanas não é servida pela coleta e tratamento dos efluentes, o risco de contaminação é efetivo, sendo verificado pelos seguintes indicadores: elevação simultânea de nitrato, cloreto e sódio e aparecimento eventual de coliformes totais e termotolerantes;

- A região do Condomínio San Diego já tem os aquíferos contaminados pela infiltração dos efluentes. A contaminação foi constatada pelo monitoramento da qualidade das águas dos poços de abastecimento e pela verificação da presença de nitrato nas águas das nascentes que são exutórios destes aquíferos;

- No Condomínio Privê Lago Norte a contaminação ainda não foi confirmada, entretanto, como o saneamento é realizado in situ na forma de fossas e sumidouros, se considera que a contaminação é apenas uma questão de tempo para que alcance a zona saturada do aquífero fraturado representado pelo Subsistema A do Sistema Paranoá;

- Os dados de monitoramento de níveis de longo período mostram que na região do condomínio San Diego as variações anuais são da ordem 10 metros. Este valor é considerado muito grande e é explicado pela posição geomorfológica em que ocorre, isto é: em borda de chapada, com grande gradiente topográfico regional;

- No sistema piloto instalado no Condomínio San Diego não se teve a confirmação de que as 
águas infiltradas nos testes hidráulicos alcançaram o poço tubular profundo situado na sua adjacência. Entretanto, a eficiência do sistema não pode ser questionada uma vez que as águas infiltradas devem ter, em sua maioria, infiltrado até a zona saturada dos aquíferos fraturados subjacentes;

- No Condomínio Privê a água que é direcionada para a caixa de recarga inicia o gotejamento para o poço escavado (cisterna) localizado a cerca de 2 metros em cerca de uma hora após o início da infiltração;

- A recarga artificial de aquíferos pode ser considerada uma ferramenta de gestão dos recursos hídricos capaz de minimizar o problema de contaminação dos aquíferos em condomínios do Distrito Federal. Mesmo que o sistema de saneamento coletivo com coleta e tratamento seja instalado, o passivo ambiental da contaminação será mantido, pois as áreas apresentam-se intensamente impermeabilizadas.

A recarga artificial como ferramenta de gestão dos recursos hídricos subterrâneos pode auxiliar de forma importante para manutenção e regularização dos processos que integram o ciclo hidrológico, uma vez que a recarga natural dos aquíferos, variável importante do referido ciclo, está prejudicada pelo uso inadequado do solo nas principais áreas de recarga regional do Distrito Federal.

\section{2 - RECOMENDAÇÕES}

O conjunto de resultados alcançados pela presente pesquisa permite que uma série de sugestões para trabalhos futuros seja recomendada, com destaque para:

- Instalação de um número maior de sistemas de recarga piloto, nas proximidades de outros poços tubulares com contaminação comprovada, para se ter maior controle da dispersão e migração das águas infiltradas. Esta ação inclusive poderá mostrar com maior precisão os caminhos de fluxo nas interfaces solo-rocha;

- Desenvolvimento de estudo geofísico previamente à instalação das caixas de recarga, de forma a se poder ter maior controle da escolha dos pontos para injeção de água de precipitação. Métodos elétricos de corrente contínua são os mais indicados, em função dos ruídos culturais potenciais em áreas urbanas;

- Realizar estudos de isótopos estáveis e outros ensaios hidráulicos para melhor controle dos tempos de chegadas das águas de recarga artificial nas zonas saturada dos aquíferos em estudo;

- Operar sistemas de recarga artificial alimentado por águas de precipitação e realizar o monitoramento por pelo menos dois anos hidrológicos consecutivos;

- Após o início de implantação da recarga artificial de forma mais ampla (em cerca de 50\% das áreas com viabilidade técnica) as nascentes da borda da chapada deverão ser o principal alvo 
de monitoramento para verificação da efetividade da ação.

Com o desenvolvimento dos trabalhos anteriormente mencionados e o conjunto de resultados obtidos pela presente pesquisa será possível alcançar um nível de conhecimento dos sistemas de recarga artificial que poderá permitir que esta ferramenta de gestão dos recursos hídricos seja regulamentada no Distrito Federal. 


\section{6 - REFERÊNCIAS BIBLIOGRÁFICAS}

ALMEIDA, L. 2011. Estudo da Aplicabilidade de Técnicas de Recarga Artificial para a Sustentabilidade das Águas Termais da Região de Caldas Novas- GO.

BAPTISTA, G.M.M. Caracterização climatológica do Distrito Federal. In: Inventário Hidrogeológico e dos Recursos Hídricos Superficiais do Distrito Federal. Brasília: Governo do Distrito Federal. Formato digital. 1998.

BARBOSA, C.M.S. \& Mattos A. 2008. Conceitos e diretrizes para recarga artificial de aquíferos. XV Congresso Brasileiro de Águas Subterrâneas. - Natal- RN.

BERGER, S.G. \& GIENTKE, F.J. 1998. Seawater intrusion reversed through artificial recharge beneath the Oxnard Plain, California.In: Artificial Recharge of Groundwater. Proceedings of the 3th International Symposium on Artificial Recharge of Groundwater. Rotterdam. p3-9.

BOAVENTURA, G.R. \& FREITAS, A.L.F. 2006. Inorganic Parameters as Water Quality Indicators in Acidic Groundwater in a Tropical Region - Brasilia-DF (Brazil). In: Water, Air, and Soil Pollution (2006) 171, p.135-151.

BOUWER, H. 2002. Artificial recharge of groundwater: hydrogeology and engineering. Hydrogeology Journal, 10:121-142.

CADAMURO, A.L.M. 2002. Proposta, Avaliação e Aplicabilidade de Técnicas de Recarga Artificial em Aquíferos Fraturados para Condomínios Residenciais do Distrito Federal. Instituto de Geociências, Universidade de Brasília, Brasília, Dissertação de Mestrado, 130p.

CADAMURO, A.L.M., Campos, J.E.G. 2002. Recarga Artificial de Aquíferos Fraturados no Distrito Federal: uma ferramenta para a gestão dos recursos hídricos. Revista Brasileira de Geociências. v. 35: p. 89-98.

CADAMURO, A.L.M., CAMPOS, J.E.G., TRÖGER, U. 2002. Artificial recharge in fractured rocks? An example from the Federal District of Brazil for the sustainability of the system. Proceedings do 4 Inter. Symp. on Artificial Recharge. Adelaide 1:56 - 60.

CADAMURO, A.L.M. \& CAMPOS,J.E.G. 2005.Recarga Artificial de Aqüíferos Fraturados no Distrito Federal: uma Ferramenta para a Gestão dos Recursos Hídricos. Revista Brasileira de Geociências. 35(1):89-98.

CAMPOS, J.E.G. 2004. Hidrogeologia do Distrito Federal: subsídios para a gestão dos recursos hídricos subterrâneos. RBG(1):41-48.

CAMPOS, J.E.G., GASPAR, M.T.P., GONÇALVES, T.D. 2007.Gestão de Recursos Hídricos Subterrâneos no Distrito Federal: Diretrizes, Legislação, Critérios Técnicos, Sistema de Informação Geográfica e Operacionalização, 153 p.

CAMPOS, J.E.G. Zoneamento Ecológico Econômico do Distrito Federal. Volume II: Meio Físico.

CAMPOS, J.E.G. 2012. Caracterização hidrogeológica e propostas para a gestão do aquífero termal da região do Projeto Aquavilla. Relatório Final. Ambiental Tecnologia Ltda. (Relatório Inédito). 56 p.

CAMPOS, J.E.G.; DARDENE, M.A.; FREITAS-SILVA, F.H.; MARTINS-FERREIRA, M.A.C. 2013. Geologia do Grupo Paranoá na Porção Externa da Faixa Brasília. Braz. J. Geol, São Paulo 43(3):461476p.

CAMPOS, J.E.G. \& CUNHA, L.S. 2015. Caracterização Hidrogeológica da Ocorrência de Aquífero Termal no Distrito Federal. Revista de Geociências, UNESP ,São Paulo v. 34, n. 2, p.210-223.

CASTANHEIRA, D. 2016. Enquadramento dos Corpos Hídricos Subterrâneos do Distrito Federal: Parâmetros Hidrogeoquímicos e Ambientais. 95p.Tese (Mestrado), Instituto de Geociências . Universidade de Brasília, Brasília- DF

COIMBRA, A.R.S.R. 1987. Balanço hídrico preliminar do Distrito Federal. In: Inventário hidrogeológico do Distrito Federal. (GDF/CAESB) Brasília DF. P. 50-78.

CHAGAS, J.M. 2008. Captação de Água de Chuva para Recarga de Aquíferos e Usos Múltiplos. Monografia de Graduação, Faculdade Araguaia, Goiânia, 40 p.

DIAMANTINO, C. 2005. Metodologias de recarga artificial de aquíferos. $7^{\circ}$ Simpósio de Hidráulica e 
Recursos Hídricos dos países de língua oficial portuguesa, Évora - Portugal.

DIAZ, J.M.M., Gomez, J.A.O., ARMAYOR, J.L. \& CATANO, S.C. 2000. Recarga Artificial de Acuíferos. Síntesis Metodológica. Estudios y Actuaciones Realizadas en la Provincia de Alicante. Editores López Geta, J.A. \& Hernandez, L.R. Consultado em 25/10/2014. Disponível em URL:http://aguas.igme.es/igme/libros2.htm

DILLON, P.2005. Future Management of Aquifer Recharge. In Hydrogeol Journal, 2005.

EMBRAPA. Mapa de solos do Distrito Federal (1:100.000). Brasília: EMBRAPA-EPI. - Serviço de Produção de Informação. 1978.

FETTER, C.W. 1994. Applied Hydrogeology. Macmillan. New York. 586p. 3rd Edition.

FREITAS-SILVA, F.H. \& CAMPOS, J.E.G. 1998. Geologia do Distrito Federal. In: Inventário hidrogeológico e dos recursos hídricos superficiais do Distrito Federal. Parte I. IEMASEMATEC/Universidade de Brasília. 86 p. (Relatório Inédito).

GALE, I. NEUMANN, I., CALOW, R.; MOENCH, M. 2002. The effectiveness of Artificial recharge of groundwater: a review. In: Groundwater Systems and Water Quality Programme. Phase 1, Final Report CR/02/108N. British Geological Survey. Keyworth, Nottingham. 82 p.

GALE, I. \& DILLON, P. 2005. Strategies for managed aquifer recharge in semi-arid areas. Edited by Ian Gale. Compiled by the International Association of Hydrogeologists- Commission on Management of Aquifer Recharge IAH - MAR, with the support of UNESCO International Hydrological Program (IHP), Project on Artificial Recharge and Management of Water Resources in Arid and Water Scarce Zones(UNESCO G-WADI) and the British Department for International Development (DFID) (Disponível em URL:http://www.iah.org/recharge/pdf/MAR_strategies.pdf).

GODOY, E.V.; GARCIA, D.S. \& FARINA, S. L. 1994. Recarga artificial de acuifero freatico en Filadelfia - Chaco Central Paraguaio. In: XIII Congr. Brasil. de Águas Subterrâneas, 385-393. Recife/PE.

GONÇALVESG, T.D. Geoprocessamento como ferramenta para a gestão dos recursos hídricos subterrâneos na região do Distrito Federal. Brasília: Universidade de Brasília/Instituto de Geociências, 2007. 225p. (Dissertação de Mestrado).

HESPANHOL, I. 2002. RBRH Potencial de Reuso de Água no Brasil Agricultura, Industria, Municípios, Recarga de Aquíferos - Revista Brasileira de Recursos Hídricos 7(4):75-95.

HTTP://nd.water.usgs.gov/. The water cycle. Acessado em 06/11/2014.

HTTP://portalsaude.saude.gov.br/images/pdf/2015/maio/25/Portaria-MS-no-2.914-12-12-2011.pdf. Acessado em 10/11/2015.

HTTP://www.climatempo.com.br/previsao-do-tempo/cidade/61/brasilia-df- Acessado em 15/11/2016.

HTTP://www.inmet.gov.br/portal/

IPEA.2010. Comunicado do IPEA n ${ }^{\circ} 44$ Brasília: Impactos Econômicos da Capital no Centro-Oeste e no País. Secretaria de Assuntos Estratégicos da Presidência da República- Governo Federal. 14p.

KATZER, T. \& BROTHERS, K. 1989. Artificial recharge in Las Vegas Valley, Clark County, Nevada. Ground Water 27(1):50-56.

KLOPPMANN, W. 2009. B and Li isotopes as intrinsic tracers for injection tests in aquifer storage and recovery systems. Applied Geochemistry 24(7):1214-1223.

KNEZEK, M. \& KUBALA, P. 1994. Experience with artificial groundwater recharge in Karany. In: Groundwater - Drought, pollution \& management, Reeve \& Watts (eds). Balkema, Rotterdam. p. 235242.

LEI COMPLEMENTAR No 803 DE 25 DE ABRIL DE 2009 com alterações decorrentes da Lei Complementar $\mathrm{n}^{\circ} 854$ de 15 de outubro de 2012. Plano Diretor de Ordenamento Territorial do Distrito Federal - PDOT disponível em http://www.segeth.df.gov.br/preservacao-e-planejamentourbano/pdot.html.

LOUSADA, E.O. 2005. Estudos hidrogeológicos e isotópicos no Distrito Federal: Modelos conceituais de fluxo. Brasília-DF. 124p. Tese de Doutorado. Instituto de Geociências, Universidade de Brasília.

LOUSADA. E.O. \& CAMPOS, J.E.G. 2005. Proposta de modelos hidrogeológicos conceituais aplicados aos aquíferos da região do Distrito Federal. Revista Brasileira de Geociências, 35(3):407-414.

MAIMONE, M. 2004. Defining and managing sustainable yield. Ground Water, 42(6):809-814. 
MARTINS, E.S.; REATTO, A.; CARVALHO JR. O.A.; GUIMARÃES, R.F. 2004. Evolução Geomorfológica do Distrito Federal. EMPRAPA. ISSN 1517-5111.

MATTHEWS, C. 1991. Using ground water basins as storage facilities in Southern California. Water Resources Bulletin, 17(5):841-847.

MIZUNO, M. G.M. 2012. Hidroquímica das Águas Subterrâneas do Distrito Federal. Brasília. 135p. Tese (Mestrado), Instituto de Geociências. Universidade de Brasília, Brasília - DF.

MONTEIRO, R.D. 2013. Avaliação de recursos hídricos e viabilidade da recarga artificial de aquíferos na bacia hidrográfica dos engenhos na Ilha de Santiago - Cabo Verde. Dissertação de Mestrado. Departamento de Ciências e Engenharia do Ambiente. Universidade Nova de Lisboa. 106 p.

MONTENEGRO S.G., MONTENEGRO, A.A., CAVALCANTI, G.L., MOURA, A.E.S. 2005. Recarga artificial de aquíferos com águas pluviais em meio urbano como alternativa para a recuperação dos níveis potenciométricos: Estudo de caso na planície do Recife (PE). In: $5^{\circ}$ Simpósio Brasileiro de Captação e Manejo de Água de Chuva. Teresina. Piauí. 10p.

MOURA, A.N. 2004. Recarga artificial de aquíferos: os desafios e riscos para garantir o suprimento futuro de água subterrânea. XIII Congresso Brasileiro de Águas Subterrâneas. São Paulo-Brasil.

MURRAY E.C \& TREDOUX G. (2002) Pilot artificial recharge schemes: testing sustainable water resource development in fractured aquifers. WRC Report No. 967/1/02

NOVAES PINTO, M. Caracterização geomorfológica do Distrito Federal. In: Novaes Pinto, M. (org). Cerrado: caracterização, ocupação e perspectivas. Brasília. Editora UnB. 2a ed.. p. 285-320. 1994.

NOVAES PINTO, M. Paisagens do cerrado no Distrito Federal. In: Novaes Pinto, M. (org). Cerrado: caracterização, ocupação e perspectivas. 2a ed. Brasília: UnB. 1994, p. 511-542.

O'SHEA, M.J.O. 1994. Drought management using artificial aquifer in north London. In: Groundwater Drought, pollution \& management, Reeve \& Watts (eds). Balkema, Rotterdam. p. 223-233.

RESOLUÇÃO CNRH No 91/2008. Dispõe sobre procedimentos gerais para o enquadramento dos corpos de água superficiais e subterrâneos.

RESOLUÇÃO CNRH No 153/2013. Estabelece critérios e diretrizes para implantação de recarga artificial de Aquíferos no território brasileiro.

RESOLUÇÃO CNRH No 15/ 2001. Estabelece que o enquadramento dos corpos de água em classes darse-á segundo as características hidrogeológicas dos aquíferos e os seus respectivos usos preponderantes, a serem especificamente definidos.

RESOLUÇÃO CONAMA N 396/ 2008. Dispõe sobre a classificação e diretrizes ambientais para o enquadramento das águas subterrâneas e dá outras providências.

RIBEIRO, M.L. \& LOURENCETTI, C.2007. Contaminação de Águas Subterrâneas por Pesticidas: Avaliação Preliminar. Química Nova, Vol. 30, No. 3, 688-694, 2007.

ROSEIRO, C. M.S.D. 2009. Recarga Artificial de Aquíferos: Aplicação ao Sistema Aquífero da Campina de Faro, Lisboa- Portugal.

SALO, J.E.D.; HARRISON, D. \& ARCHIBALD, E.M. 1986. Removing contaminants by groundwater recharge basins. Journal, American Water Works Association, 78(79):76-81

SANKARANNA, G. 2002 .Impact of water harvesting structures on ground water development : A study from Chittoor District, Andhra Pradesh, India. pp. 305-308. In Management of aquifer recharge for sustainability. Proceedings of the 4th Intl. Symp. on Artificial Recharge of Ground Water, ISAR4, Adelaide, Australia, ed. P.J. Dillon., A.A. Balkema Publishers, Tokyo, 2002.

SEWRPC. 2006. "State-of-the-Art of Water Supply Practices". Southeastern Wisconsin Regional Planning Commission (SEWRPC). Technical Report N. ${ }^{\circ}$ 43, Chapter VI - Artificial Groundwater Recharge and Management (preliminary Draft) (Disponível em URLhttp://www.sewrpc.org/watersupplystudy/pdfs/tr-43_chapter-6_preliminary_draft.pdf).

SILVA, G.E.S. 2004. Avaliação do Potencial da Recarga Artificial como Alternativa para Recuperação da Potenciometria de Aquífero: Estudo de Caso na Planície do Recife-PE. Dissertação de Mestrado. Universidade Federal de Pernambuco, 145 p.

SILVA, G.E.S., MONTENEGRO, S.M.G.L., COSTA, L.M. 2004. Modelagem numérica de recarga artificial em aquífero costeiro na planície do Recife (Brasil). XXV CILAMCE - Iberian Latin American Congress on Computational Methods. Recife, PE. XXP. 
TOPPER, R., BARKMANN, P.E., BIRD, D.R., and SARES, M.A. 2004. Colorado Geological Survey Department of Natural Resources, Artificial Recharge of Ground Water In Colorado - A Statewide Assessment, 2004. By E.P. Weeks A Historical Overview of Hydrologic Studies of Artificial Recharge in the U.S. Geological Survey U.S. Geological Survey Artificial Recharge Workshop Proceedings, Sacramento, California, April 2-4, 2002 (OFR 02-89) (Disponível em URL http://water.usgs.gov/ogw/pubs/ ofr0289/ofr0289.pdf).

VANIER, C.L.; HIRATA, R. 2009. Nitrogen effect from septic systems in an unconfined aquifer in São Paulo, Brasil. In: Groundwater and Human Development. Special Publication ed. Amsterdan: Balkema.

VANIER, C.L.; HIRATA, R.; ARAVENA, R. 2008. Uso de isótopos estáveis e gases para avaliação de desnitrificação na zona não saturada do Aquífero Adamantina (Urânia, SP). XV Congr. Bras. de Águas Subterrâneas. Natal. CDRom.

VIEIRA, A.D.M., LEITE, O.D., OLIVEIRA J.L.S., ALMEIDA M.C., GEORGE L. 2013. Avaliação dos Indicadores de Contaminação por Esgoto em Águas Subterrâneas da Cidade de Barreiras/BA. XX Simpósio Brasileiro de Recursos Hídricos. ISSN 2318-0358. Bento Gonçalves- RS.

WHITEHEAD \& GEARY, 2000. Geotechnical aspects of domestic on-site effluent management systems. Australian Journal of Earth Sciences Volume 47(1):75-82.

ZOBY, J.L.G. Hidrogeologia de Brasília - DF. Bacia do Ribeirão Sobradinho. São Paulo: Universidade de São Paulo / Instituto de Geociências, 1999. (Dissertação de Mestrado). 132p. 